\title{
35. THE CENOMANIAN/TURONIAN BOUNDARY EVENT (CTBE) AT HOLE 641A, ODP LEG 103 (COMPARED WITH THE CTBE INTERVAL AT SITE 398) ${ }^{1}$
}

\author{
J. Thurow, ${ }^{2}$ M. Moullade, ${ }^{3}$ H.-J. Brumsack, ${ }^{4}$ E. Masure, ${ }^{5}$ J. Taugourdeau-Lantz,${ }^{6}$ and K. Dunham ${ }^{7}$
}

\begin{abstract}
Drilling at ODP Site 641 (on the western margin of Galicia Bank, off northwestern Spain) revealed a thin, but pronounced, interval of black shale and gray-green claystone. Our high-resolution study combines the sedimentology, micropaleontology (palynomorphs and others), organic and inorganic geochemistry, and isotopic values of this layer to demonstrate the distinct nature of the sediment and prove that the sequence represents the local sedimentary expression of the global Cenomanian/Turonian Oceanic Anoxic Event (OAE) of Schlanger and Jenkyns (1976), Arthur and Schlanger (1979), and Jenkyns (1980), also called the Cenomanian/Turonian Boundary Event (CTBE).

The most striking evidence is that the strong positive $\delta^{13} \mathrm{C}$ excursion characterizing the CTBE sequences in shallow areas can be traced into a pronounced deep-sea expression, thus providing a good stratigraphic marker for the CTBE in various paleosettings. The isotopic excursion at Site 641 coincides with an extremely enriched trace metal content, with values that were previously unknown for the Cretaceous Atlantic. Similar to other CTBE occurrences, the organic carbon content is high (up to $11 \%$ ) and the organic matter is of dominantly marine origin (kerogen type II).

The bulk mineralogy of the CTBE sediments does not differ significantly from the general trend of Cretaceous North Atlantic sediments (dominance of smectite and zeolite with minor amounts of illite and scattered palygorskite, kaolinite, and chlorite); thus, no evidence for either increased volcanic activity nor a drastic climatic change in the borderlands was found.

Results from Site 641 are compared with the CTBE section found at Site 398, DSDP Leg 47B (Vigo Seamount at the
\end{abstract} southern end of the Galicia Bank).

\section{INTRODUCTION}

In the deeper marine environment, the Cenomanian/Turonian boundary is marked globally by the presence of laminated, organic-carbon-rich (of marine planktonic origin) black shales that commonly lack any signs of benthic life. Such sediments occur within a wide range of paleobathymetric and paleogeographic settings (e.g., Schlanger and Jenkyns, 1976; Wiedmann et al., 1978, 1982; Arthur and Schlanger, 1979; Jenkyns, 1980; Schlanger and Cita, 1982; Thurow et al. 1982; Herbin et al. 1986b; Arthur et al., 1987; Schlanger et al., 1987). This boundary event, originally termed the Cenomanian/Turonian Oceanic Anoxic Event (OAE) (Schlanger and Jenkyns 1976), and subsequently referred to as the Bonarelli Event, the Oceanic Anoxic Event 2 (OAE 2), the Evénement 2 (E 2 = OAE 2), and the Cenomanian/Turonian Boundary Event (CTBE), has become one of the most studied Mesozoic oceanic events.

The term "oceanic event" is used to express the occurrence of something influencing the oceans and thereby affecting a wide variety of oceanic features (e.g., marine biota). Demonstration that something happened requires that the event be distinct, that it can be dated precisely, and that conditions preceding and following the event differ. The CTBE, as it is now known, fits this definition, but more precise biostratigraphic

\footnotetext{
${ }^{1}$ Boillot, G., Winterer, E. L., et al., 1988. Proc. ODP, Sci. Results, 103: College Station, TX (Ocean Drilling Program)

2 Institut und Museum für Geologie und Paläontologie, Universität Tübingen, Tübingen, Federal Republic of Germany.

${ }^{3}$ Laboratoire de Micropaléontologie et Géologie Marines, Université de Nice, Nice, France.

4 Geochemisches Institut, Universität Göttingen, Göttingen, Federal Republic of Germany.

5 Laboratoire de Micropaléontologie, Département de Géologie Sédimentaire, Université Pierre et Marie Curie, Paris, France.

6 Laboratoire de Micropaléontologie, Université Paris VI, Paris, France.

7 Oceanography Program, Department of Geological Sciences, The University of Michigan, Ann Arbor, MI.
}

and chemostratigraphic work is needed to determine if this is a globally distinct event.

A distinct layer of carbonaceous claystone or marlstone, famous for fish fossils at some localities, is well known between Albian and Turonian (or younger) onshore outcrops at numerous locations throughout the northern hemisphere. Classical areas include the Black Band (Yorkshire) and Pläner (northern Germany) epicontinental deposits and the Livello Bonarelli, a radiolarian-rich, carbonaceous claystone in the pelagic continental margin series of central (Apennines) and northern Italy (Southern Alps).

Thurow et al. (1982) and Kuhnt et al. (1986) made detailed biostratigraphic investigations, based on planktonic foraminifers and radiolarians, of several sections with differing paleobathymetric settings that include a distinct black shale layer suspected to reflect the CTBE in the western Tethys (Italy, Spain, and Morocco). These authors were able to demonstrate that the black band is consistent over time for a wide area. Their conclusions verify the claims of Schlanger and Jenkyns (1976) and Jenkyns (1980), who reviewed the literature and noted that similar horizons of sediment rich in organic carbon are widespread in shallow and pelagic deposits, and those of Arthur and Premoli Silva (1982), who studied the classical areas in Italy. Furthermore, the ready comparison of faunal results by Thurow et al. (1982) with the macrofossil- and microfossil-bearing sections of the northwest African coastal basins (Wiedmann et al., 1978, 1982) has led to the development of a valuable standard. Concurrent with this work, de Graciansky et al. (1982), and subsequently Müller et al. $(1983,1984)$, established their Evénement 2 ( = Cenomanian/Turonian OAE of Schlanger and Jenkyns, 1976) to characterize a distinct layer in North Atlantic Cretaceous sequences. This layer is described as a laminated black claystone rich in marine organic matter and with a very low sedimentation rate, overlain by a multicolored claystone interval, and dated as Cenomanian and possibly basal Turonian. Herbin et al. (1986b) and Thurow and Kuhnt (1986) introduced the term CTBE for this layer in the North Atlantic and similar se- 
quences in the western Tethys. This special type of Cretaceous sedimentation can also be traced into the Western Interior Seaway of the United States (Pratt and Threlkeld, 1984; Herbin et al., 1986b).

Apart from the distinct and unique black shale sedimentation, the most obvious effect of the CTBE in open-marine environments is a bloom in radiolarians that lasted until middle $\mathrm{Tu}$ ronian. This increased abundance is more obvious in the Atlantic realm, where radiolarians of Late Cretaceous age are scarce. The high biogenic silica content is another source for the common formation of zeolites or chert in CTBE sediments. From a biological point of view, the CTBE coincides with important changes in the evolution of planktonic microfossils and, to some extent, also to benthics; the latter have not been studied in detail. Several radiolarian groups became extinct with the onset of the CTBE, whereas several others have their first-appearance datum (FAD) during this event. These evolutionary trends are, in part, obviously related to the major changes in marine habitats that probably affected the life cycles of planktonic forms. For example, the loss of the habitat of deeper dwelling (keeled) planktonic foraminifers led to an increased taxonomic turnover of this group, which recurred immediately after the end of the CTBE. Furthermore, changes in the chemical patterns, besides those apparent in the black shales, are also pronounced. A distinct positive $\delta^{13} \mathrm{C}$ spike marks the boundary (e.g., Schlanger and Jenkyns, 1976; Scholle and Arthur, 1980; Pratt and Threlkeld, 1984; Arthur et al., 1987; Schlanger et al., 1987), and enrichments of trace metals from deep-water environments are exceptionally high (Brumsack, 1980; Brumsack and Thurow, 1986). The isotopic excursion is also reflected in sequences that lack other geochemical or sedimentary expressions of the CTBE. Marine strata deposited during the CTBE display lithologic, faunal, and geochemical characteristics indicating that significant parts of the world's oceans were periodically oxygen deficient. This condition is especially evident in the black laminated anoxic shales that appear to be restricted to an expanded $\mathrm{O}_{2}$ minimum zone (Arthur et al. 1987; Schlanger et al., 1987).

The global CTBE has been variously related to transgression, global upwelling, cool climate, bolide impacts ${ }^{8}$, (volcanic) extrusions, or a combination of several of these phenomena. However, an ultimately satisfying explanation and model is still lacking.

Site 641 , at $42^{\circ} 09.3^{\prime} \mathrm{N}, 12^{\circ} 10.9^{\prime} \mathrm{W}$ (Fig. 1A), was drilled during Ocean Drilling Program (ODP) Leg 103 to core all of the post-rift and the top of the syn-rift Cretaceous sequence of the Galicia margin (Boillot et al., 1985; Shipboard Scientific Party, 1987a). The drill site is on the landward flank of a half-graben structure formed by the westernmost prominent tilted block at the Galicia margin (Fig. 1B). At this site, recovery of the transition interval between the Hatteras Formation and the Plantagenet Formation was marked by the CTBE interval. We estimate a paleowater depth of approximately $3500 \mathrm{~m}$ during the CTBE.

Drilling penetrated a sequence of post-rift sediments and the carbonate-free, organic-matter-rich interval that characterizes the CTBE (Pl. 3, Fig. 1), from Samples 103-641A-6X-7, $17 \mathrm{~cm}$, through 103-641A-6X, CC $(20 \mathrm{~cm})$, which corresponds to lithologic Unit IB (brown clay in Core 103-641A-3X through Sample 103-641A-6X-7, $27 \mathrm{~cm} ; 15.7-53.6 \mathrm{~m}$ below seafloor [mbsf]) and lithologic Unit II (black zeolitic clay in Samples 103-641A-6X-7, $27 \mathrm{~cm}$, to $103-641 \mathrm{~A}-6 \mathrm{X}, \mathrm{CC}$ [20 cm]; 53.6-53.9 mbsf) (Fig. 2) (Shipboard Scientific Party, 1987b).

\footnotetext{
${ }^{8}$ Samples stinct iridium-rich layers were found recently in the Western Interior Seaway (Pueblo section; Fig. 9) (E. G. Kauffman, pers. comm., 1987).
}

Similar sequences are commonly recorded from other sites in the deeper North Atlantic, as well as from onshore outcrops in Europe and northwest Africa (compilation in Herbin et al., 1986b). Examples include the southern part of the Galicia margin at Deep Sea Drilling Project (DSDP) Site 398 (Fig. 1A) and a counterpart along the Western Atlantic margin, DSDP Site 105 , at the northern termination of the Hatteras Abyssal Plain (Pl. 3, Fig. 2).

At the approximately mid-Cenomanian age top of the cyclic black shale/gray-green marly claystone sequence of the Hatteras Formation, the sedimentation rate and the calcium carbonate content decrease sharply (Pl. 6, Fig. 3; Evénement 2 of Müller et al., 1983, 1984). The middle and upper Cenomanian are condensed to a few centimeters (Pl. 6, Fig. 1), a phenomenon that has also been detected at several onshore locations. Age assignment is possible only from palynomorphs. Above this condensed horizon, which Haq et al. (1987, their fig. 3) reported as a global occurrence, a black shale sequence of variable thickness (for example, several meters thick at Site 367, Cape Verde Basin) and with a distinct fissile character ("papershale") was deposited. This sequence is commonly marked by the first occurrence of the radiolarian species Crucella cachensis, which coincides with the last occurrence of the planktonic foraminifer Rotalipora cushmani and the beginning of the Whiteinella archaeocretacea foraminiferal zone and the Quadrum gartneri nannofossil zone. These zones comprise the uppermost Cenomanian/lowermost Turonian.

However, dating this event at many sites remains complicated by the lack of zonations used to include, correlate, and calibrate microfossils to the macrofossil standard zonation. This problem is reflected in our biostratigraphic results.

The sedimentary expression of the end of the CTBE is not as pronounced as that of the onset. In general, the black shale sedimentation disappears prior to the decrease in the high siliceous microfossil content. Rich radiolarian faunas can persist into the first reddish (oxic) sediments, as at Site 398 (Thurow, this volume). Onshore, the decline of radiolarians occurs in the Praeglobotruncana helvetica foraminiferal zone, in approximately the middle Turonian. This standard sequence was influenced by local phenomena such as detrital input close to borderlands, marine erosion and resedimentation, or changes in the $\mathrm{O}_{2}$ content, which was the cause of cyclic sedimentation of black and gray-green shales at Site 398 (Pl. 5, Figs. 3 and 4).

\section{LITHOLOGIES AT CTBE INTERVALS}

\section{Site 641}

Hole 641A penetrated Late Cretaceous age brown clays (lithologic Unit I; Shipboard Scientific Party, 1987b) overlying a sequence of black and gray-green claystone and marlstone of early Late Cretaceous age (lithologic Units II and III). The lithologic units of Hole 641A can be compared to the oceanic formations of Jansa et al. (1979) for the North Atlantic Basin.

The CTBE at Hole $641 \mathrm{~A}$ is represented by the 30 -cm-thick black shale layer of lithologic Unit II. The sedimentary sequence covering the CTBE can be separated into five lithologic units, mainly on the basis of sediment color (Pl. 3, Fig. 1), designated as Units A through E in this chapter (Fig. 2 and Pls. 1 and 2).

\section{Unit A: Lithologic Subunit IB (Core 103-641A-3X to Sample 103-641A-6X-7, $17 \mathrm{~m}$;}

Unit A, distinguished by its brown color and homogeneity, is the local expression of the Plantagenet Formation, which is the Upper Cretaceous and lower Tertiary strata in the type area. The lower boundary of the brown clay sequence in Hole 641A is at 53.5 mbsf (Sample 103-641A-6X-7, $17 \mathrm{~cm}$ ). 


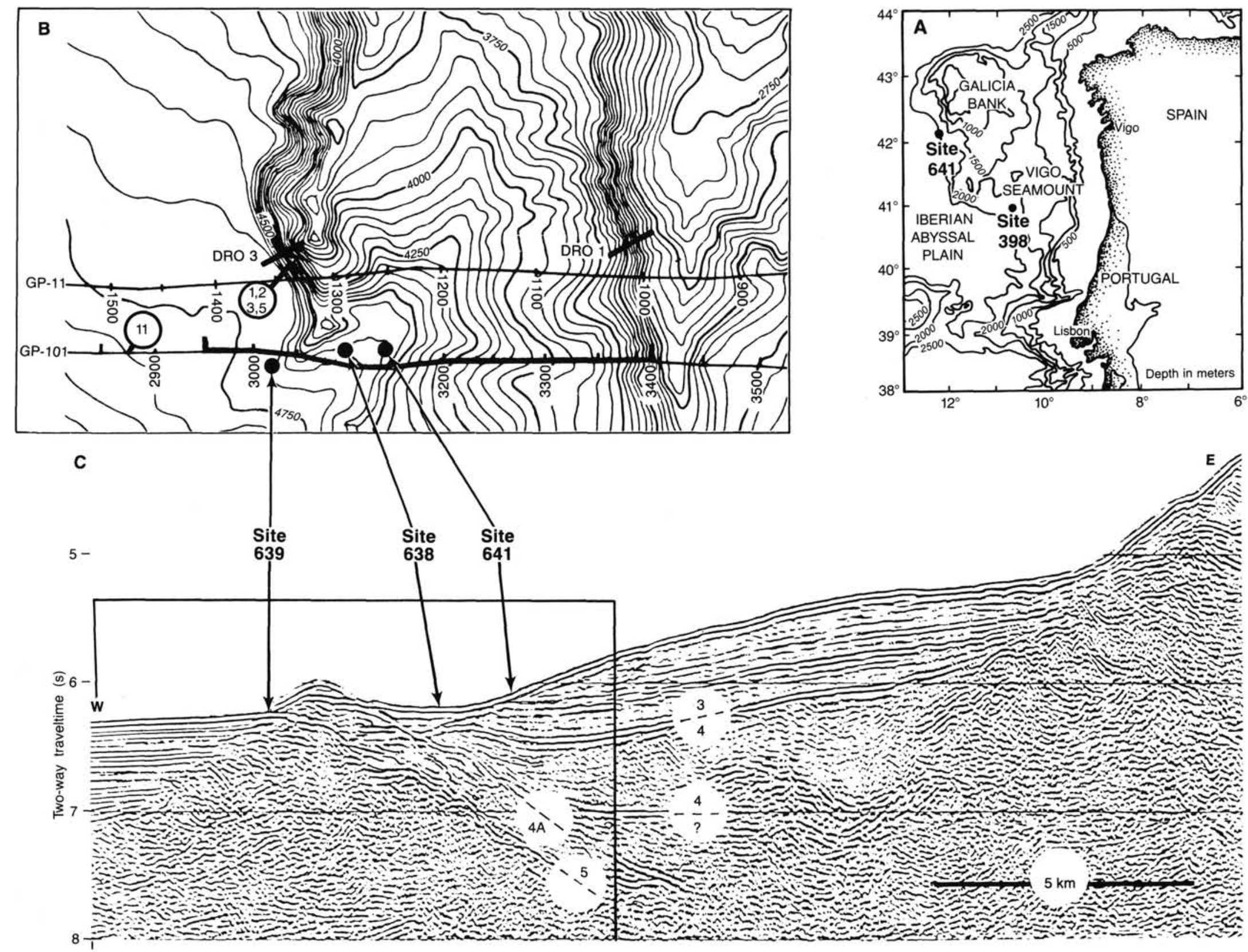

Figure 1.A. Bathymetric map and geographic location of Sites 641 and 398 on the Iberian margin. Contour interval $500 \mathrm{~m}$. B. Sea Beam map of the area near Sites 638,639 , and 641 covering the last pronounced tilted block. Contour interval in meters. C. Multichannel seismic profile GP-101, from shotpoints 2950 to 3400 , showing the location of Sites 638,639 , and $641.3=$ post-rift strata; 4 and $5=$ syn-rift strata. The reflector between seismic units 3 and 4 is interpreted as reflecting the break-up unconformity (Aptian transition from rifting to spreading). The CTBE black shale layer occurs immediately above this reflector. Vertical scale in $\mathrm{s}$ two-way traveltime. 


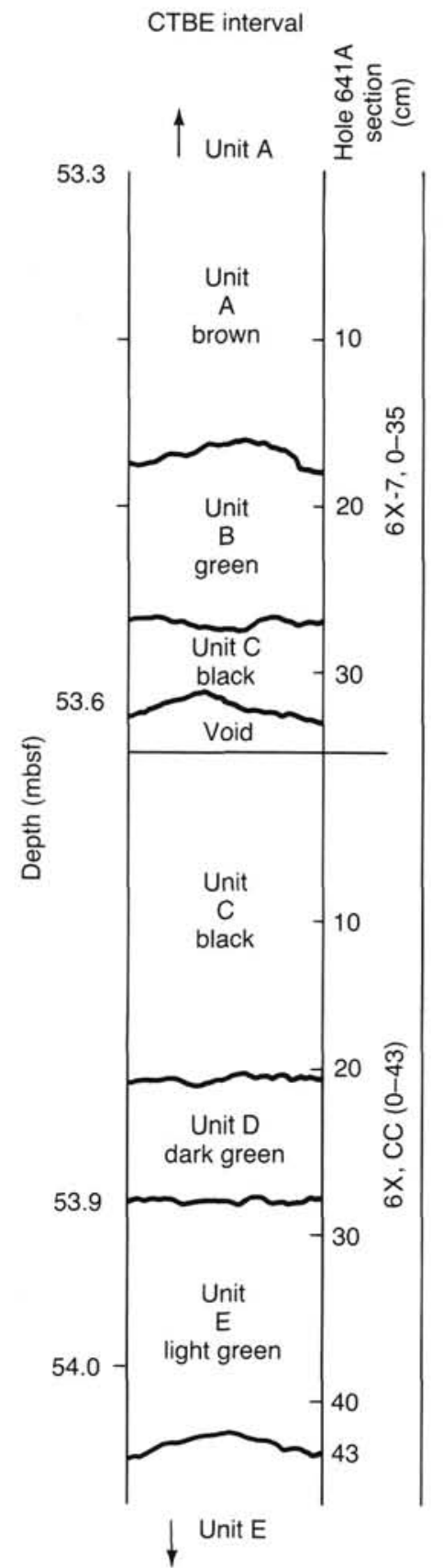

Figure 2. The CTBE interval at Site 641. Lithologic units are defined by sediment color (compare with Plates 1 and 2).

The Unit A sequence consists of brown and dark grayish brown clay. The brown and dark brown clays alternate on a 10 30 -cm scale. Dark grayish brown spots of manganese oxide-rich clay (up to $2 \mathrm{~cm}$ across) are found in the upper part of the unit, and $\mathrm{Mn}$ values reach $0.5 \%$. The clay becomes redder and brighter in color with depth. Other than a slight suggestion of mottling, no internal structures or lamination are evident, even from $\mathrm{X}$-ray micrographs (Pl. 1). Unit A is devoid of carbonate, and smear slide analysis suggests that the clays are extensively recrystallized, which is confirmed by the SEM (Pl. 6, Fig. 1).

The brown clay consists dominantly of smectite, with minor amounts of illite, palygorskite, and kaolinite (Table 1). No detrital minerals were detected by X-ray diffraction (XRD), nor do $\mathrm{X}$-ray micrographs show any evidence of detrital layers (the white dots in Plate 1 are interpreted as large barite crystals). Shipboard analysis of smear slides reported fine silt-sized quartz in amounts up to $10 \%$ from Cores 103-641A-5X and 103-641A6X (Shipboard Scientific Party, 1987b), but this abundance was not confirmed by micropaleontological preparations $(>40-\mu \mathrm{m}$ fraction). Coarser grained components include microfossils, Mnand $\mathrm{Fe}$-carbonates, and/or dolomite microconcretions, with shapes resembling poorly preserved radiolarians (Pl. 6, Fig. 2), that comprise up to $1 \%$ of the sediment (for analysis see Thurow, this volume).

The elemental compositions of five brown clay samples from Unit $\mathrm{A}$ are listed in Appendix A.

Unit B (Samples 103-64A-6X-7, $17 \mathrm{~cm}$, to 103-641A-6X-7, 27 cm; 53.5-53.6 mbsf)

The bottom $10 \mathrm{~cm}$ of the sequence above the CTBE (the lowermost part of the Plantagenet Formation) consists of greenish gray clay that darkens downward $(5 \mathrm{G} 5 / 1)$. The clay content decreases slightly, whereas authigenic crystals (mainly zeolites) become more evident. The boundary between Units A and B is rather sharp but disturbed by drilling; the boundary between Unit B and the underlying black shale of Unit C is sharp with no indication of erosion or hiatus. X-ray micrographs show that the large barite crystals disappear and lamination (slightly disturbed by drilling) is visible exactly at the $\mathrm{B} / \mathrm{C}$ contact (Pl. 1).

Under the microscope, the greenish gray clay appears identical in all respects to the brown clay above. The color is attributed to the effect of the immediately underlying, highly reduced black clay of Unit C. X-ray micrographs show that the abundance of the large crystals increases from the lowermost part of the brown clay into the greenish gray clay (Pl. 1). Inorganic geochemistry documents a prominent change in the content of manganese, $3 \mathrm{~cm}$ above the boundary between the greenish gray and brown clay. The Mn value drops from $4565 \mathrm{ppm}$ in Section 103$641 \mathrm{~A}-5 \mathrm{X}, \mathrm{CC}$, to $450 \mathrm{ppm}$ in the brown clay from Sample 103641A-6X-7, 11-14 cm (Appendix A). Sample 103-641A-6X-7, $15-18 \mathrm{~cm}$, (dominantly brown clay with a small amount of greenish gray clay) has trace metal content similar to the brown clay samples (Appendix A), which also documents that there is no important sedimentary difference between the brown clay and the greenish gray clay intervals. This is further confirmed by the presence of agglutinated benthic foraminifers, a faunal group that is generally missing because of depauperation or the lack of $\mathrm{O}_{2}$ in the deep-water environments affected by the CTBE.

A drastic change in the trace metal pattern is evident in the uppermost black shale sample, which was slightly contaminated with greenish gray clay (Pl. 1 and Appendix A). The most obvious change is the strong increase of some trace metals, especially $\mathrm{Ag}, \mathrm{Cd}$, and $\mathrm{U}$.

\section{Unit C (Samples 103-641A-6X-7, $27 \mathrm{~cm}$, to 103-641A-6X, CC [20 cm]; 53.6-53.9 mbsf)}

Unit C consists of a uniform, structureless dark black zeolitic clay with a distinct fissile character (Pl. 5, Fig. 1). The upper and lower boundaries of Unit $C$ are sharp and show no evidence of erosion or a hiatus in accumulation. X-ray micrographs again reveal no distinct fine lamination (Pls. 1 and 2). The observed structures are interpreted as drilling effects. The white lenses are of unknown mineralogy and origin (Pl. 2, micrograph on the right side). The total clay content decreases sharply (Fig. $3 \mathrm{~A})$, and the sediment is devoid of carbonate. Smear slides as well as SEM analyses show that, in addition to recrystallized clay, the sediment contains large amounts of zeolite (PI. 5, Fig. 2). Shipboard smear slides revealed up to $10 \%$ zeolite, but SEM studies revealed that a large part of the sediment consists of zeolites (Fig. 3A and Pl. 5, Fig. 3). Cretaceous zeolite-rich facies in 
Table 1. XRD results of selected CTBE samples from Sites 641 and 398. Clay minerals are numbered according to their relative abundance in the clay fraction; higher numbers indicate decreasing amounts; smectite, the dominant clay mineral in all samples, is number 1. Quartz is of detrital or biogenic origin, calcite from planktonic foraminifers. Zeolite is probably an alteration product of radiolarian tests. Mica and feldspars are of detrital origin. The origin of chlorite, which forms only a small part of the samples, is uncertain, but it may be partially detrital. The microplankton content common in samples from the CTBE interval at Site 398 is not shown.

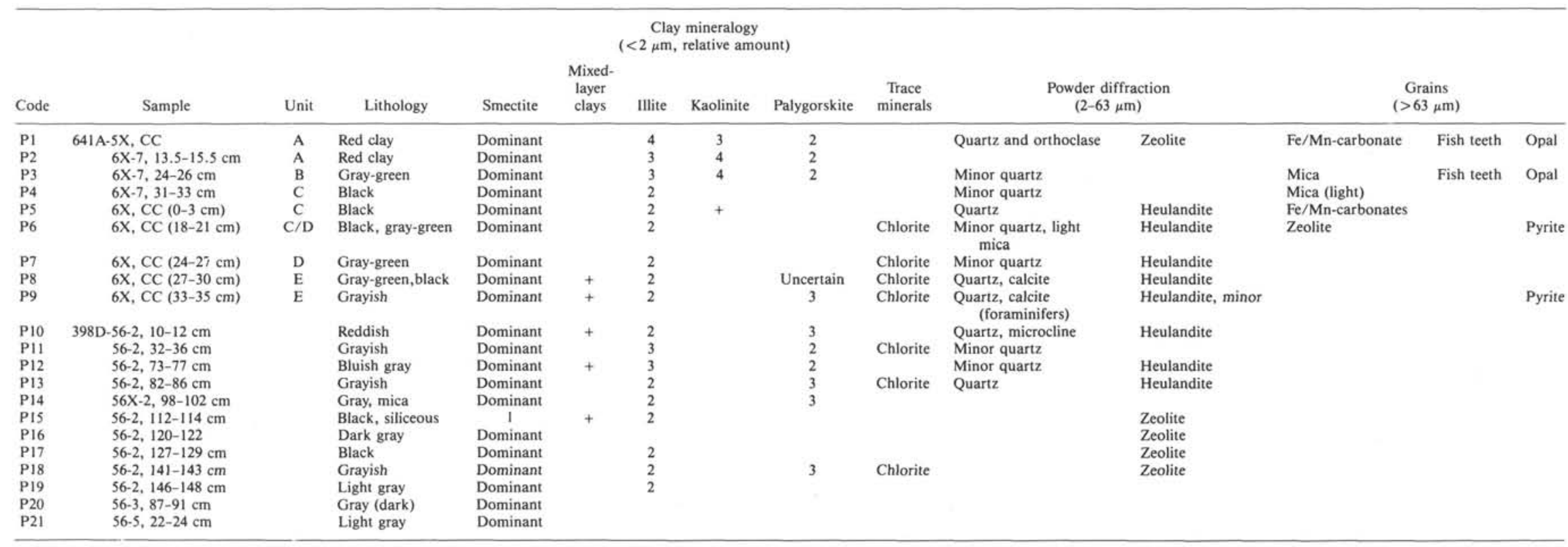




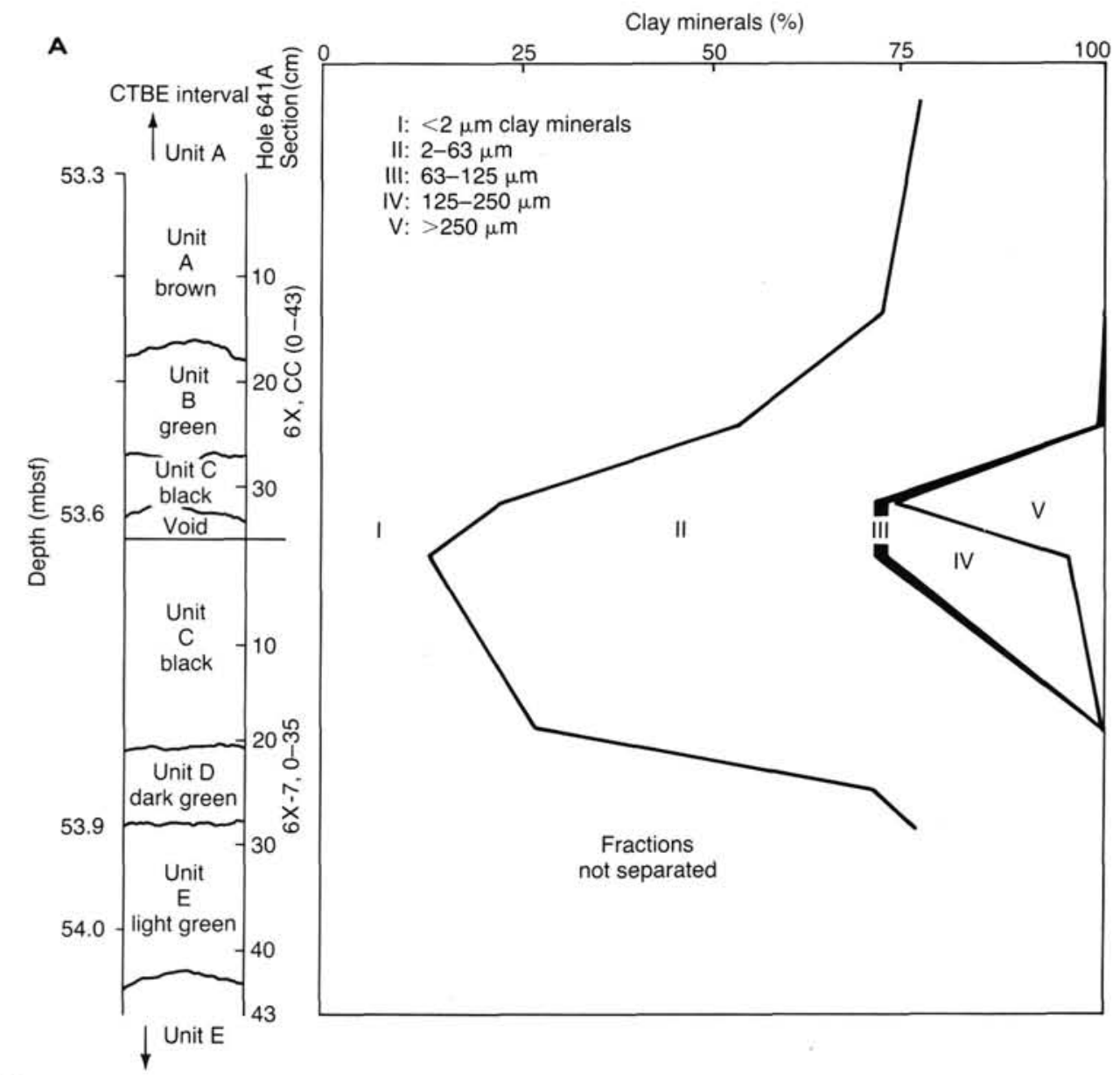

B

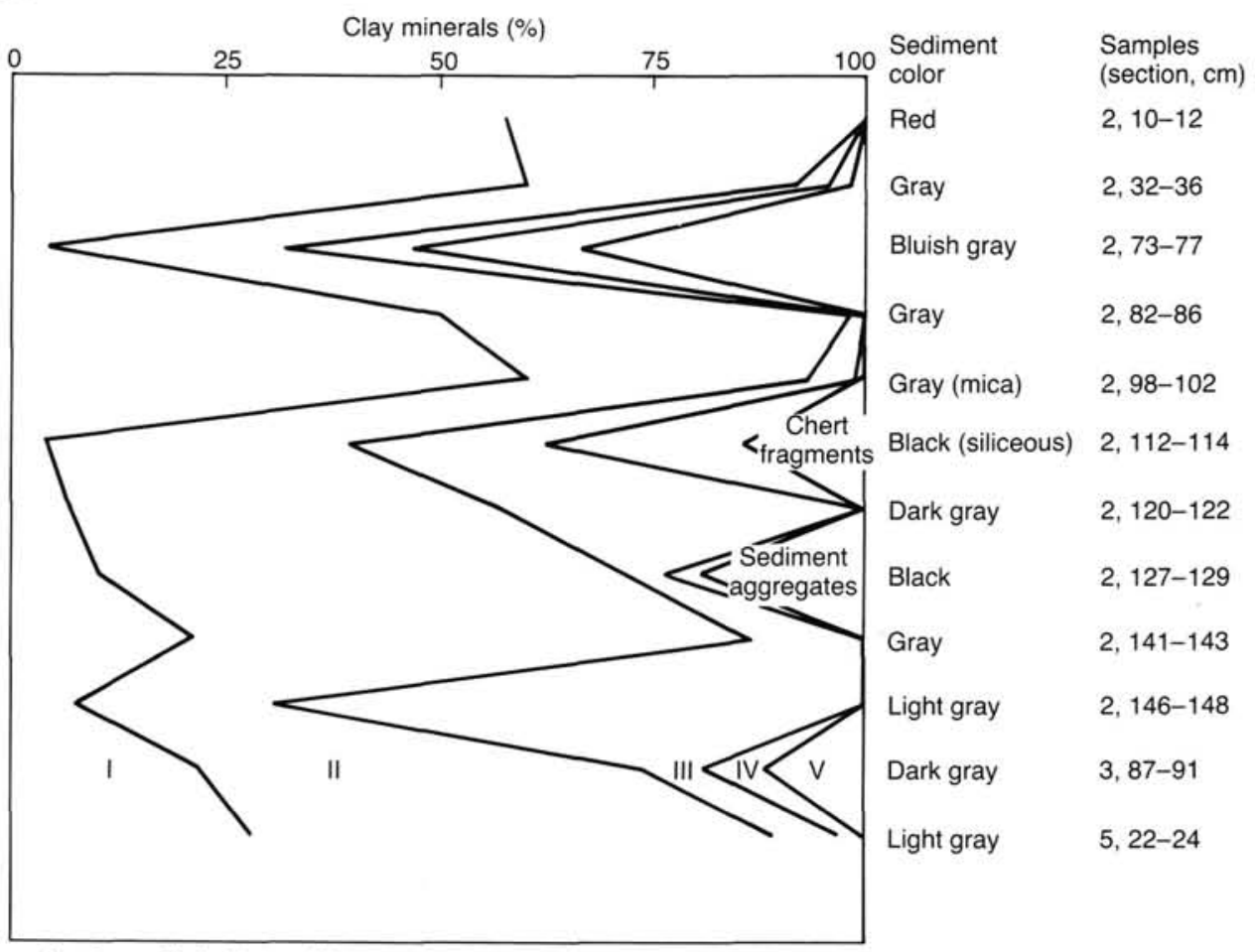

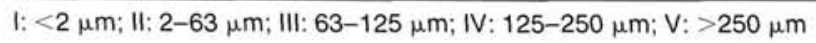

Figure 3. A. Percentages of clay minerals and detrital or authigenic minerals (zeolite) around the CTBE interval at Hole 641A. B. Percentages of clay minerals and detrital or authigenic minerals (zeolites) around the CTBE interval at Core 398D-56. 
the North Atlantic are generally dominated by clinoptilolite (see the following discussion of mineralogy). Clay minerals are smectite and illite; no kaolinite was detected (Figs. 4C and 4D). In addition, rare quartz, pyrite (PI. 5, Figs. 4 and 6), and up to $11 \%$ organic carbon are important components. Unit $\mathrm{C}$ can be described as belonging to the xenomorphic palynofacies of $\mathrm{Ha}$ bib (1979b), dominated by amorphous palynodebris, but with the presence of some palynomorphs (Pl. 5, Fig. 5; compare with the section on palynomorphs).

Inorganic geochemistry data show a dramatic change in the values for several trace metals (Appendix A), which also demonstrates the unique nature of the black shale band.

\section{Unit D (Samples 103-641A-6X, CC [20 cm] to 103-641A-6X, CC $[27 \mathrm{~cm}])$}

Unit D consists of greenish gray claystone with a large increase in the amount of clay (Fig. 3A) and a slight increase in carbonate content. Biogenic carbonate (nannofossils) was detected first in Sample 103-641A-6X, CC (25 cm) (Pl. 6, Fig. 3). The contact with overlying Unit $\mathrm{C}$ is sharp and underlined by a thin brownish layer (Pl. 2), which is interpreted as a sequence that is highly condensed or of almost zero sedimentation. This sharp boundary indicates that the depositional environment changed abruptly following the accumulation of Unit D (Event 2 of Müller et al., 1983, 1984). However, SEM studies revealed no significant change above this contact. Both lithologies have similar mineralogies, dominated by a distinct pattern of zeolite and clay minerals (Fig. 4E), and even pyrite remaining present at the top of Unit D. The contact to the underlying Unit E is transitional, and Unit D differs principally from Unit E by its darker color and lack of carbonate. It is not clear if the decrease in carbonate in respect to the dissolution of the nannofossils (Pl. 6, Fig. 3) can be explained by a rise in the carbonate compensation depth (CCD) or if it resulted from the proximity of the overlying black shale layer.

\section{Unit E (Sample 103-641A-6X, CC [27 cm], through Core 103-641A-7X; 54-> 63.6 mbsf)}

Unit $\mathrm{E}$ is composed of light greenish gray and gray nannofossil marl and calcareous clay. A high clay mineral content recurs in this unit. X-ray micrographs show internal structures, which can be interpreted as drilling disturbance (Pl. 2). There is no evidence of lamination, mottling, or even bioturbation.

Smear slide and SEM analyses show that the sediment consists principally of clay and nannofossils, rare detrital quartz, calcareous foraminifers, and what is still a notable amount of zeolite (Table 1). The clay mineral spectrum is again dominated by smectite, with lesser amounts of illite and rare chlorite (Fig. $4 \mathrm{~F}$ and Table 1). The carbonate content increases from zero in the upper part of Unit D to almost $50 \%$ in Unit E. Unit E is organic carbon poor. Nannofossil and foraminiferal occurrences date Unit E as late Albian and early Cenomanian.

Deposits below Unit E were recovered from the upper part of the Hatteras Formation in Hole $641 \mathrm{C}$ and consist of dark, relatively organic-rich and carbonate-poor black claystone and slightly calcareous claystone with increasing carbonate content with depth. This sequence is Aptian and Albian. The black shales have a distinct layering (Pl. 6, Fig. 4) and again, are enriched in biogenic-derived zeolite and opal-CT, as well as framboidal pyrite. The organic matter of terrestrial origin does not exceed $5 \%$ of the total organic content (Table 2).

\section{Site 398}

The expression of the CTBE interval at Site 398 is not obvious, but a sedimentological break resulting from condensed sedimentation (Rehault and Mauffret, 1979) occurs in Sample 398D$56-2,19 \mathrm{~cm}$, between two lithologic units that are equivalent to the Hatteras and Plantagenet Formations.
The deposits of the upper part of the Hatteras Formation consist of dark, relatively organic-rich and carbonate-poor shales and mudstones (Pl. 4, Fig. 1, right column). During the early and middle Albian, the sedimentation rate was very high (greater than $100 \mathrm{~m} / \mathrm{m} . \mathrm{y}$.), and the organic matter of terrestrial origin does not exceed $1 \%$ total organic carbon. This high sedimentation rate is interpreted to be the consequence of regional subsidence. During the late Albian and early Cenomanian, the sedimentation rate decreased $(15 \mathrm{~m} / \mathrm{m} . \mathrm{y}$.) as the transgression began, decreasing to less than $1 \mathrm{~m} / \mathrm{m}$.y. during the CTBE (Herbin et al., $1986 \mathrm{~b}$ ), with a considerable amount of material provided by turbidites.

The depositional environment and the facies of the background sedimentation are quite similar to those at Site 641 during the CTBE, but widespread dilution by detrital material and the intercalation of thin turbidites gives them a less pronounced expression.

The base of the Plantagenet Formation (equivalent to Units A and B at Site 641) in Section 398D-55-2 is characterized by dark red brown unburrowed mudstone (Pl. 4, Fig. 1, left column) composed of $70 \%-80 \%$ clay (dominantly smectite), $10 \%$ $20 \%$ zeolite, and minor amounts of quartz (?opal-CT) and mica (Fig. 3B and Table 1). Beginning at a drilling contact and extending down from Section 398D-56-1 are deposits of grayish green, green-gray, and reddish brown variegated zeolitic claystone. The sediment is structureless except for several coarser laminae (PI. 4, Fig. 2); below Sample 398D-56-2, $75 \mathrm{~cm}$, the dominant lithology is a nannofossil marlstone to calcareous mudstone, grayish green, moderately burrowed, and with numerous varying lithologies (mainly of redeposited layers). The sediments include clay, quartz, and clinoptilolite of diagenetic origin. They are almost devoid of $\mathrm{CaCO}_{3}$.

Sediment redistribution is obvious in Sections 2 and 3 (Pl. 4, Fig. 1, center) of Core 398D-56. Lithologies include gray-green laminated silty claystone, white to bluish graded quartzose sandstone, grayish green to grayish black graded mud-chip sandstone, and silty graded marl, with erosional contacts and some $30 \%$ to $40 \% \mathrm{CaCO}_{3}$, containing reworked microfossils (Pl. 4, Fig. 5; note the distinct coarse-grained calcareous turbidite at the base of the fourth section). Layers strongly enriched in radiolarians (Pl. 4, Fig. 2) might have formed either because of sediment winnowing or as a result of concentration of radiolarians by bottom currents and/or fine-grained turbidites.

Several 5-cm-thick intervals of thinly laminated, dark gray to grayish black unburrowed claystone are striking local expressions of the CTBE black shale layer in Sections 2 and 3 of Core 398D-56 (Pl. 4, Fig. 1, center). SEM studies revealed the typical fissile character of the CTBE black shales with scattered pyrite crystals or framboids of pyrite. Samples from Section 398D-56-2 have the typical organic geochemistry characteristics: total organic carbon reaches $10 \%$ and the organic matter is of dominantly marine origin (amorphous kerogen; Herbin et al., 1986b). Habib (1979b) described the interval as belonging to his xenomorphic palynofacies type (amorphous palynodebris composed mostly of optically translucent yellow, brown, and orange particles), which supports the organic geochemistry results. However, the black shales differ in their inorganic geochemical character, with a low trace metal content and nonuniform distribution pattern. The bulk mineralogy is similar to that of Unit $\mathrm{C}$ at Site 641 (see the following section on mineralogy). Burrows are observed at the boundaries of these black shales with adjacent lighter (oxic) lithologies (Pl. 6, Figs. 5 and 6).

\section{MINERALOGY}

Detailed mineralogical, chemical, and lithological investigations of Mesozoic sediments from the numerous DSDP sites at the North Atlantic margins indicate that the contribution of autochthonous sources is insignificant in comparison to the conti- 
Table 2. Compilation of biostratigraphy and organic geochemistry studies at Hole 641A. Reference codes for ages: AG = agglutinated foraminifers; $\mathbf{R A}=$ radiolarians; NA = nannofossil floras; FO = planktonic foraminifers; $\mathbf{D I}=$ dinoflagellates; $\mathbf{P O}=$ pollen grains; $\mathbf{S P}=\mathbf{s p o r e s}$. Analysis: RE $=$ Rock Eval. Investigators: BRU $=$ H.-J. Brumsack; DUN $=$ K. Dunham; IFP $=$ J. P. Herbin, Institut Français du Pétrole.

\begin{tabular}{|c|c|c|c|c|c|c|c|c|c|}
\hline Sample & $\begin{array}{l}\text { Depth } \\
\text { (mbsf) }\end{array}$ & Unit & $\begin{array}{l}\text { Sediment } \\
\text { color }\end{array}$ & Age & Reference & Age & Reference & Age & Reference \\
\hline $3 \mathrm{X}, \mathrm{CC}$ & & A & Red & Santonian/Campanian & AG & & & & \\
\hline $4 X-1,80-82 \mathrm{~cm}$ & 26.10 & A & Red & Santonian & $\mathrm{AG}$ & & & & \\
\hline $4 \mathrm{X}, \mathrm{CC}$ & & A & Red & Santonian & AG & & & & \\
\hline $5 X-2,107-112 \mathrm{~cm}$ & 37.47 & A & Red & Coniacian & AG & & & & \\
\hline $5 \mathrm{X}, \mathrm{CC}$ & & A & Red & Turonian/Coniacian & AG & & & & \\
\hline $6 \mathrm{X}-7,11-14 \mathrm{~cm}$ & 53.61 & A & Red & Turonian/Coniacian & AG & & & & \\
\hline $6 \times-7,15-18 \mathrm{~cm}$ & 53.65 & $\mathrm{~A} / \mathrm{B}$ & Red/green & Turonian/Coniacian & AG & late $\mathrm{m}$ Cenomanian & DI & late Cenomanian & $\mathrm{PO} / \mathrm{SP}$ \\
\hline $6 \mathrm{X}-7,21-24 \mathrm{~cm}$ & 53.71 & B & Green & Turonian/Coniacian & AG & & & & \\
\hline $6 \mathrm{X}-7,24-25 \mathrm{~cm}$ & & B & Green & & & & & & \\
\hline $\begin{array}{l}6 \mathrm{X}-7,26-29 \mathrm{~cm} \\
6 \mathrm{X}-7,29-30 \mathrm{~cm}\end{array}$ & 53.76 & $\begin{array}{c}\mathrm{B} / \mathrm{C} \\
\mathrm{C}\end{array}$ & $\begin{array}{l}\text { Black/green } \\
\text { Black }\end{array}$ & Turonian/Coniacian & AG & late $\mathrm{m}$ Cenomanian & DI & late Cenomanian & $\mathrm{PO} / \mathrm{SP}$ \\
\hline $6 \mathrm{X}-7,30-31 \mathrm{~cm}$ & & $\mathrm{C}$ & Black & & & & & & \\
\hline $6 \mathrm{X}-7,31 \mathrm{~cm}$ & 53.81 & C & Black & & & & & & \\
\hline $6 X-7,31-33 \mathrm{~cm}$ & 53.81 & $\mathrm{C}$ & Black & & & late m Cenomanian & DI & late Cenomanian & $\mathrm{PO} / \mathrm{SP}$ \\
\hline $6 \mathrm{X}, \mathrm{CC}(0-3 \mathrm{~cm})$ & 53.85 & C & Black & & & late $\mathrm{m}$ Cenomanian & DI & late Cenomanian & $\mathrm{PO} / \mathrm{SP}$ \\
\hline $6 \mathrm{X}, \mathrm{CC}(3-6 \mathrm{~cm})$ & 53.88 & $\mathrm{C}$ & Black & & & & & & \\
\hline $6 \mathrm{X}, \mathrm{CC}(8-11 \mathrm{~cm})$ & 53.93 & C & Black & & & late m Cenomanian & DI & late Cenomanian & $\mathrm{PO} / \mathrm{SP}$ \\
\hline $6 \mathrm{X}, \mathrm{CC}(11 \mathrm{~cm})$ & 53.96 & $\mathrm{C}$ & Black & & & & & & \\
\hline $6 \mathrm{X}, \mathrm{CC}(16 \mathrm{~cm})$ & 54.01 & $\mathrm{C}$ & Black & & & & & & \\
\hline $6 \mathrm{X}, \mathrm{CC}(16-17 \mathrm{~cm})$ & & C & Black & & & & & & \\
\hline $6 \mathrm{X}, \mathrm{CC}(18-21 \mathrm{~cm})$ & 54.03 & $\mathrm{C} / \mathrm{D}$ & Black/green & & & late m Cenomanian & DI & late Cenomanian & $\mathrm{PO} / \mathrm{SP}$ \\
\hline $6 \mathrm{X}, \mathrm{CC}(20 \mathrm{~cm})$ & 54.05 & $\mathrm{C}$ & Black & & & & & & \\
\hline $6 \mathrm{X}, \mathrm{CC}(21-24 \mathrm{~cm})$ & 54.06 & D & Dark green & e-m Turonian & RA & late $\mathrm{m}$ Cenomanian & DI & late Cenomanian & $\mathrm{PO} / \mathrm{SP}$ \\
\hline $6 \mathrm{X}, \mathrm{CC}(24-27 \mathrm{~cm})$ & 54.09 & D & Dark green & m Cenomanian & NA & late $\mathrm{m}$ Cenomanian & DI & late Cenomanian & PO/SP \\
\hline $6 \mathrm{X}, \mathrm{CC}(27-30 \mathrm{~cm})$ & 54.12 & E & Greenish gray & m Cenomanian & NA & late m Cenomanian & DI & & \\
\hline $6 \mathrm{X}, \mathrm{CC}(31-34 \mathrm{~cm})$ & & $\mathrm{E}$ & Greenish gray & e-m Cenomanian & NA & & & & \\
\hline $6 \mathrm{X}, \mathrm{CC}(34-35 \mathrm{~cm})$ & & E & Greenish gray & & & & & & \\
\hline $6 \mathrm{X}, \mathrm{CC}(35-37 \mathrm{~cm})$ & & $\mathrm{E}$ & Greenish gray & e-m Cenomanian & NA & e-m Cenomanian & DI & late Cenomanian & $\mathrm{PO} / \mathrm{SP}$ \\
\hline $6 \mathrm{X}, \mathrm{CC}(38-39 \mathrm{~cm})$ & & $\mathrm{E}$ & Greenish gray & & & & & & \\
\hline $7 X-1,6-7 \mathrm{~cm}$ & 54.16 & E & Greenish gray & $\begin{array}{c}\text { late Albian/early } \\
\text { Cenomanian }\end{array}$ & FO/NA & & & & \\
\hline $7 X-1,84-86 \mathrm{~cm}$ & & $\mathrm{E}$ & Greenish gray & & & e Cenomanian & DI & ? & $\mathrm{PO} / \mathrm{SP}$ \\
\hline $7 X-1,100-103 \mathrm{~cm}$ & 55.10 & $\mathrm{E}$ & Greenish gray & $\begin{array}{c}\text { late Albian/early } \\
\text { Cenomanian }\end{array}$ & FO/NA & & & & \\
\hline $7 \mathrm{X}-3,24-26 \mathrm{~cm}$ & & E & Greenish gray & 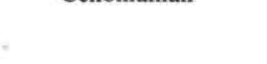 & & $\begin{array}{l}\text { late Albian/early } \\
\text { Cenomanian }\end{array}$ & DI & late Albian & $\mathrm{PO} / \mathrm{SP}$ \\
\hline $7 X-4,88-90 \mathrm{~cm}$ & & E & Greenish gray & & & $\begin{array}{l}\text { late Albian/early } \\
\text { Cenomanian }\end{array}$ & DI & & \\
\hline $7 X-5,10-15 \mathrm{~cm}$ & 60.20 & E & Greenish gray & $\begin{array}{c}\text { late Albian/early } \\
\text { Cenomanian }\end{array}$ & FO/NA & & & & \\
\hline $7 X-5,19-21 \mathrm{~cm}$ & 60.29 & E & Greenish gray & $\begin{array}{l}\text { late Albian/early } \\
\text { Cenomanian }\end{array}$ & FO/NA & & & & \\
\hline $7 X-5,21-23 \mathrm{~cm}$ & & $\mathrm{E}$ & Greenish gray & & & $\begin{array}{c}\text { late Albian/early } \\
\text { Cenomanian }\end{array}$ & DI & late Albian & $\mathrm{PO} / \mathrm{SP}$ \\
\hline $7 X, C C(18-20 \mathrm{~cm})$ & & E & Greenish gray & & & $\begin{array}{l}\text { late Albian/early } \\
\text { Cenomanian }\end{array}$ & DI & & \\
\hline $7 \mathrm{X}, \mathrm{CC}$ & & $\mathrm{E}$ & Greenish gray & 1 Albian & $\mathrm{FO} / \mathrm{NA}$ & & & & \\
\hline
\end{tabular}

nental detrital supply. Thus, the clay sediments reflect continental environmental variations (Chamley, 1979), and the inorganic mineralogy and geochemistry of deep-sea sedimentary sequences express the paleoenvironments of the ocean borderlands and margins for any given geologic period or geographic area. In addition to providing valuable data about the geological history of the hinterlands, the clay minerals are also an important source for data about possible volcanic activities as well as the climatic history.

Detailed high-resolution studies of the sediment mineralogy around the CTBE interval are not yet available; therefore, we analyzed samples from Units A through E of Site 641 to see if the CTBE is reflected in the bulk mineralogy and clay mineral assemblages. To discriminate local clay sedimentation as well as detrital input, 12 samples from Site 398 were studied for compari- son. Site 398 was deposited in a shallower environment and was thus more effected by the geology of the borderland.

Our approach is not to present a quantitative analysis of clay minerals - the validity of such analysis is questionable because of the large potential errors. A semiquantitative estimation of the relative amount of minerals per bulk sample is the basis of the clay mineral content $(<2 \mu \mathrm{m})$ presented in Figures 3-5, along with powder diffraction data, for each sample.

\section{METHODS}

The bulk mineralogy and amount and type of clay minerals were determined for 21 samples from Sites 398 and 641 , including all of the different lithologies associated with the CTBE interval.

The samples were vibrated in water for $50 \mathrm{hr}$, with the silicified samples slightly crushed first. Wet sieving was used to separate the coarse 
Table 2 (continued).

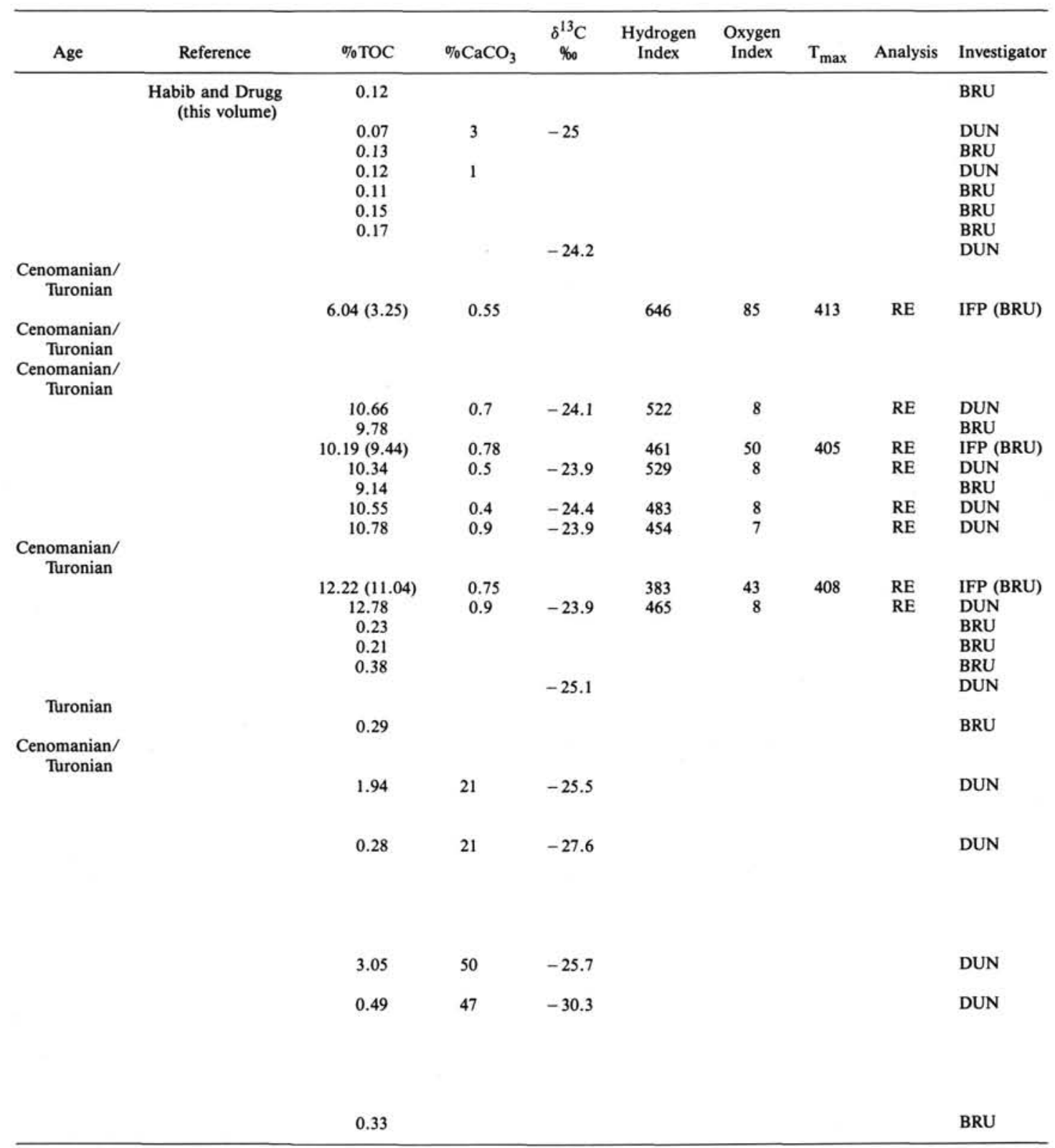

fraction for microfossils and detrital and authigenic minerals. Material greater than $63 \mu \mathrm{m}$ was suspended and deposited in an Atterberg cylinder according to hydrodynamic-equivalent diameter. The fraction less than $2 \mu \mathrm{m}$ was sedimented on glass slides. While drying, clay minerals orient with their basal planes parallel to the slide, which enhances the (001) reflections. Most samples were also exposed to an glycol atmosphere for the recognition of expandable clay minerals. Some samples were heated to allow discrimination between kaolinite and chlorite (kaolinite is not stable beyond $400^{\circ} \mathrm{C}$ ).

XRD analyses were run from $2^{\circ}-46^{\circ} 2 \theta$ up to the (005) reflection peak of illite (2-30 \&; displays in Fig. 4 are restricted to 3-30 \&). The standard for $2 \theta$ is Cu- $\mathrm{K}_{\alpha}$. Clay minerals were identified by their characteristic basal XRD maxima. Semiquantitative clay percentages were determined on the glycolated X-ray analog records using the method described by Meyer and Davies (this volume).

\section{Results}

Results of powder diffraction and texture preparations are compiled in Table 1; selected samples are shown in Figure 4.
The relative amount of clay is displayed in Figures $3 \mathrm{~A}$ and $3 \mathrm{~B}$. Percentages of clay minerals are tabulated in Figure 5.

\section{Site 641}

\section{Unit A}

The clay content of the Unit A brown clays is high, and the clay mineral spectrum is quite uniform. Smectite strongly dominates over palygorskite, illite, and kaolinite. The detected quartz is inherited from agglutinated foraminifers, and orthoclase is probably of authigenic origin. In the $2-63-\mu \mathrm{m}$ fraction, quartz and alkaline feldspars form significant peaks. Studies of washed residues revealed agglutinated foraminifers, fish teeth, and some considerable amounts of $\mathrm{Mn}$-carbonate (plus rare $\mathrm{Mn} / \mathrm{Fe}$-carbonate) and/or dolomite microconcretions, termed "pseudoradiolarians" because of their apparent spherical outline (Pl. 6, Fig. 2). Pseudoradiolarians comprise up to $1 \%$ of the sample from Section 103-641A-5X, CC (Thurow, this volume). 

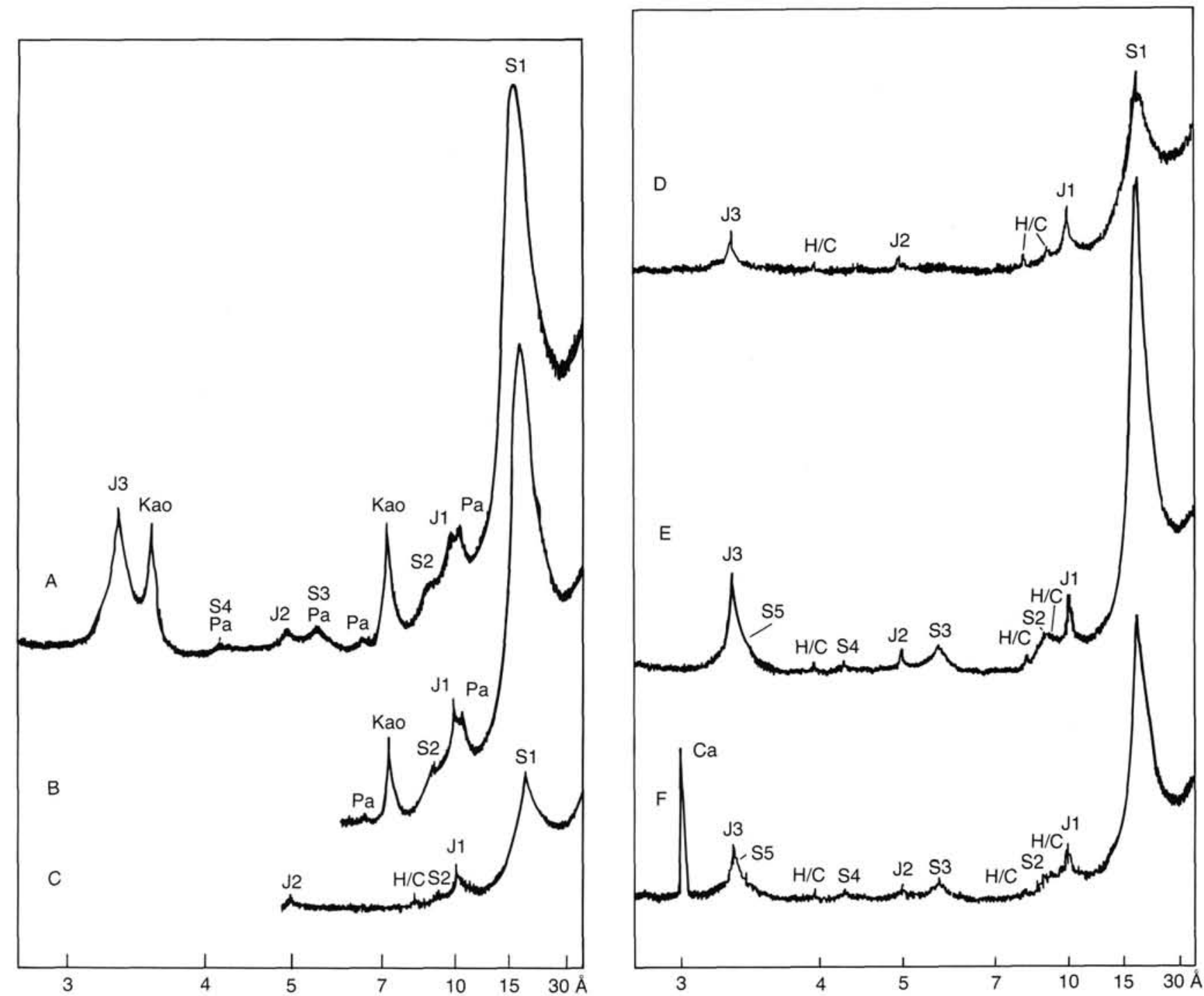

Figure 4. XRD pattern of selected clay mineral assemblages from Hole 641A. Smectite $=\mathrm{S}$; illite = J; kaolinite = Kao; palygorskite $=$ PA; heulandite $/$ clinoptilolite = H/C; calcite = Ca. A. Sample 103-641A-6X-7, 13.5-15.5 cm (P2); Unit A (brownish clay of the Plantagenet Formation). Note the dominance of smectite and prominent peaks of kaolinite and palygorskite. B. Sample 103-641A-6X-7, 24-26 cm (P3); Unit B (greenish clay). The pattern is similar to Figure 4A. C. Sample 103-641A-6X-7, 31-33 cm (P4); Unit C (black shale). Note the lack of kaolinite and palygorskite and the less pronounced peaks of smectite and illite. D. Sample 103-641A-6X, CC $(0-3 \mathrm{~cm})(\mathrm{P} 5)$; Unit C (black shale). The black shale within Unit C shows no significant differences. E. Sample 103-641A-6X, CC (24-27 cm) (P7); Unit D (dark green clay). Note the reoccurrence of strong smectite peaks and the considerable amount of zeolite that remains. F. Sample 103-641A-6X, CC (33-35 cm) (P9); Unit E (pale green clay). Note the high carbonate content (nannofossils).

$\mathrm{XRD}$ analyses proved the carbonate to be pure dolomite. EDAX analyses from similar crystals in other samples from Unit A revealed pronounced Mn peaks (plus rare Fe peaks); thus, rhodochrosite is probably present. Another common residue from the brown clay consists of large, flat tabular barite crystals $(\sim 2 \mathrm{~mm})$. Figure $4 \mathrm{~A}$ is a clay mineral pattern from a brown clay sample devoid of detrital components greater than $63 \mu \mathrm{m}$.

\section{Unit $B$}

Other than a $25 \%$ decrease in clay content, the sediments of Unit B do not differ significantly from those of Unit A in mineralogical composition (Table 1).

\section{Unit C Black Shale}

The clay mineral content is very low in the Unit C black shale (Fig. 3A), with smectite again as the dominant clay mineral. No palygorskite and kaolinite were detected. Some quartz (eolian?) was found in the $2-63-\mu \mathrm{m}$ fraction. Unit $C$ has the first large proportion of zeolites (clinoptilolite/heulandite) in the bulk mineral content (Figs. 4C and 4D; Pl. 5, Fig. 3). In the transition to Unit $\mathrm{D}$, the first occurrence of chlorite was detected.

\section{Units $D$ and $E$}

The clay content of samples from Units D and E is high, with both units showing a similar pattern in bulk mineralogy, dominated by smectite with minor amounts of illite. Parts of the units are distinguished by zeolites, as well as some quartz and light-colored mica. Additional mixed-layer minerals characterize Unit E (Table 1 and Figs. 4E and 4F). The high carbonate content is derived from nannofossils and, to a lesser extent, planktonic foraminifers. Part of the quartz content probably results from agglutinated foraminifers. 


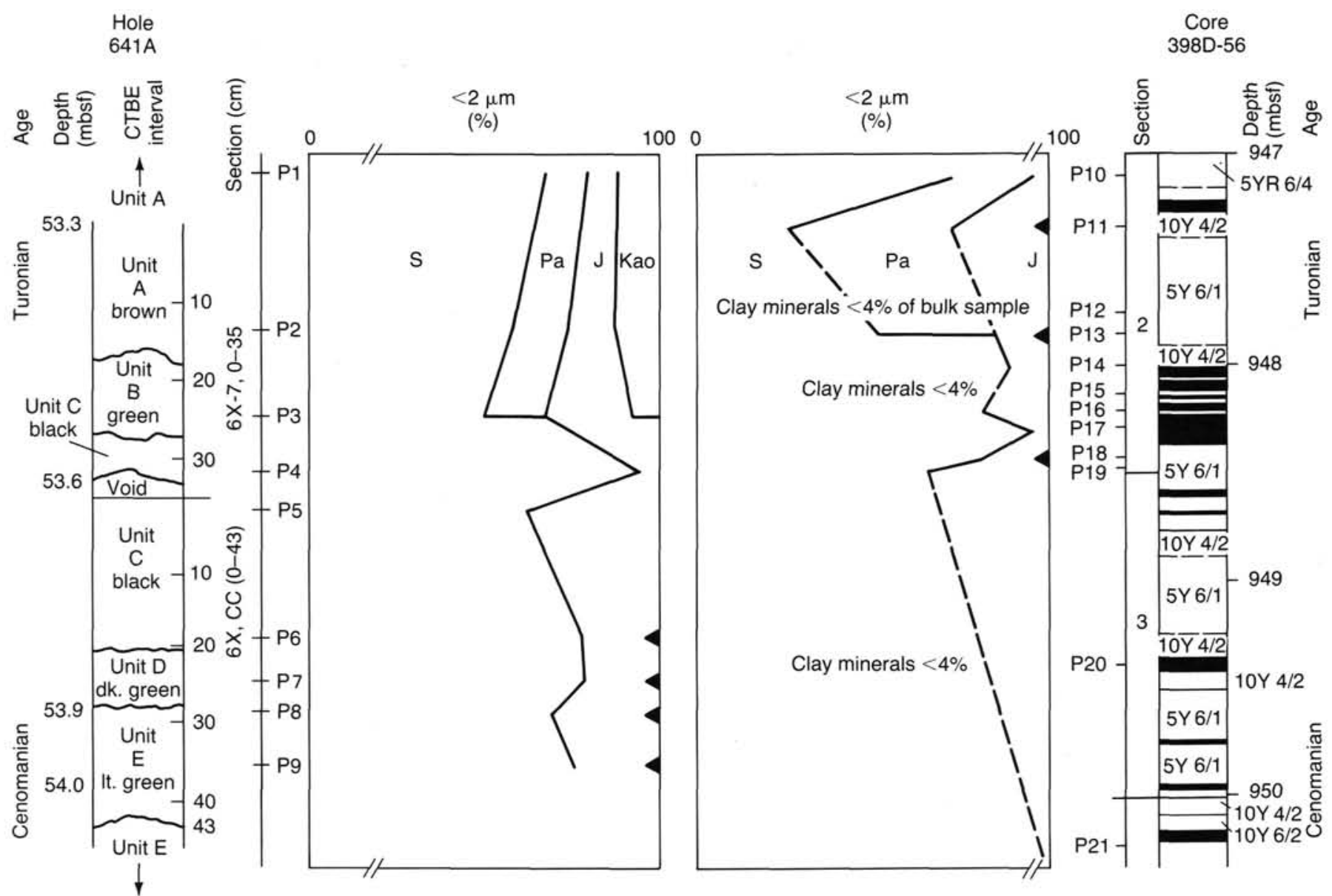

Figure 5. Relative precentages of clay minerals near the CTBE intervals at Holes 398D and 641A. Smectite $=\mathrm{S}$; illite $=\mathrm{J}$; kaolinite $=\mathrm{Kao}$; palygorskite $=\mathrm{Pa}$; trace of chlorite $=$ solid triangle. Hole 398D rock colors from Herbin et al. (1986a).

The clay mineral composition in the CTBE interval at Site 641 is quite uniform and similar to the total clay mineral spectra observed in all of the Leg 103 samples (Meyer and Davies, this volume).

\section{Site 398}

Samples from Site 398 include all of the different lithologies and sediment colors observed for the CTBE interval.

The clay fraction is characterized by abundant and well-crystallized smectite, in association with small amounts of illite, palygorskite, mixed-layer clay, and traces of chlorite. Zeolites are common, and there are some lithic components (e.g., chert). Only a few variations are noticed within this interval. The total clay content varies considerably (Fig. 3B), but this is mostly a result of insufficient preparation for the silicified samples. However, the organic-carbon-rich samples have low clay contents (Fig. 3B).

The mineralogy of the CTBE samples from Site 398 is similar to those from Site 641. Regardless of color, all of the samples are dominated by smectite. Illite is present, except in two samples below the CTBE interval. Palygorskite is present in the upper part of the CTBE interval (approximately in the Turonian), no kaolinite was detected, and there are scattered occurrences of chlorite and mixed-layer clays, as well as zeolites (Table 1). Clinoptilolite is very abundant and is generally present in vugs, mostly inside partially dissolved foraminifer and radiolarian tests (PI. 4, Fig. 5).

Some layers in the CTBE interval at Site 398 have common opal-CT, which was not detected with the XRD (e.g., Pl. 6,
Figs. 5 and 6). Because this siliceous mineral results from diagenetic alteration of biogenic silica, opal-CT usually occurs in association with biogenic remains (Riech and von Rad, 1979), which are abundant in Cretaceous deposits (Thurow, this volume). SEM studies show crystals of clinoptilolite associated with opal-CT lepispheres (Thurow, this volume). The formation of these minerals chiefly from biogenic silica precludes a necessary dependence on volcanogenic supplies.

\section{Discussion}

Variety and variability characterize the clay minerals in the sections studied from Sites 641 and 398. Primary minerals, derived from crystalline rocks, occur in the clays, along with smectite, fibrous clay minerals, kaolinite, and irregular mixed-layer minerals. All of these form under low-temperature-low-pressure conditions, at which they are stable. Compilations of clay mineral studies of middle Cretaceous sequences of the North Atlantic are provided by Chamley (1979), Chamley and Debrabant (1984), and Chamley and Deconinck (1985). According to these authors, on the basis on several North Atlantic sites (including Site 398), there is no appreciable sign of diagenesis with depth of burial in the clay mineral spectrum of Mesozoic deposits of the North Atlantic margins. Furthermore, the predominant part of the clay minerals in the Cretaceous North Atlantic is of detrital origin. However, the occurrence of dolomite- and $\mathrm{Mn} / \mathrm{Fe}-\mathrm{mi}-$ croconcretions reflects diagenesis, at least in the brown clays of Unit A at Site 641.

Smectite is the dominant clay mineral in the Cretaceous North Atlantic, regardless of sediment type. Smectite is common and 
does not differ chemically in either the Upper Cretaceous brown clays deposited under oxic conditions or in the Lower to middle Cretaceous black shales deposited under anoxic conditions. This is also confirmed by studies from both of the CTBE intervals. Smectite formation is often correlated to volcano-hydrothermal mechanisms (Grim and Güven, 1978). However, in most cases this hypothesis is unsupported. Smectite abundance is not systematically connected with the presence of volcanic materials or typical volcanic-derived minerals. Smectite is commonly very abundant in sections devoid of volcanic manifestations (most Cretaceous sediments) and vice versa (Chamley, 1979). A nonvolcanic source for smectite is also supported by rare-earth associations, which point to a continental source (Coutois and Chamley, 1978).

Palygorskite is common, although it is found in low abundance in the Mesozoic series on both Atlantic margins. Some parts of the section are marked by increased palygorskite abundance, especially in the Albian. Restricted areas, in which the supplied ions were trapped and crystallization occurred, could have been the preferred environment for the formation of palygorskite. The formation of such enclosed or semiclosed marginal seas that were at least temporarily isolated from the open sea might have resulted from the transgressive/regressive cycles onlapping low-relief borderlands at this time.

Illite and chlorite, common constituents of the Cretaceous clay spectrum in the North Atlantic, are derived from crystalline borderlands. Crystalline complexes, which were at least partly exposed in the Cretaceous, are numerous in the vicinity of the Galicia margin.

Kaolinite sedimentation is rarely recorded in the North Atlantic Cretaceous, with its contribution decreasing to the present day. This clay mineral forms mainly as a result of hydrolysis of feldspar minerals from crystalline complexes or sedimentary rocks, which were common in the borderlands of the Galicia margin. The hot and arid Cretaceous climate in the low latitudes was not favorable for the formation of large amounts of kaolinite. Furthermore, most of the kaolinite formed was trapped in the borderlands and thus, rarely transported into the ocean. The middle and Late Cretaceous peak of transgressive flooding of the borderlands during the CTBE might have caused strong hydrolysis and increased transport of kaolinite to the margin, ultimately resulting in kaolinite deposited in the troughs between the tilted blocks. This model is supported by the comparably high kaolinite content in Late Cretaceous age North Atlantic sediments.

Determination of the type of zeolites found in the samples was problematic. Zeolites in the Cretaceous sediments of the North Atlantic are recorded mainly as clinoptilolite (Stonecipher, 1976, 1978; Kastner and Stonecipher, 1978; Mélières, 1979; Thurow, this volume). The zeolite chemistry is always characterized by a high silica content, and the $\mathrm{Ca}$ content is not as low in clinoptilolites from carbonate-bearing sediment and chalk: in some places the percentage of $\mathrm{Ca}$ plus $\mathrm{Mg}$ may be high enough to distinguish the mineral heulandite. In the studied North Atlantic samples, including those from the CTBE intervals, the Ca content of the clinoptilolite is low, even from carbonate-bearing sediments; thus, the mineral clinoptilolite is inferred. The results of the heating test (Mumpton, 1960), a method commonly used to distinguish between heulandite and clinoptilolite, showed that the zeolite mineral is clinoptilolite (Thurow, this volume). Mélières (1979) studied comparable sediments in the North Atlantic and showed that the zeolites are true clinoptilolites. XRD analyses of Galicia margin zeolites show a pattern dominated by clinoptilolite peaks, but additional peaks indicate that a certain amount of heulandite is also present.

The presence of clinoptilolite is commonly related to volcanic activity and the deposition of volcanic glass in the deep sea (e.g., Gottardi and Galli, 1985), but no obvious relation- ships have been detected in the samples studied. Clinoptilolite is present in nearly all of the major lithologies, whether calcareous or not. It is common in Lower Cretaceous strata with comparably high sedimentation rates, as well as in Upper Cretaceous strata with very low sedimentation rates. This relation is also valid for several coeval and lithologically comparable sites in the North Atlantic (Mélières, 1979; Otsuka, 1985). Furthermore, it is obvious from SEM, thin section, and washed residue studies that zeolite is associated more commonly with partially dissolved siliceous remains (chiefly radiolarians) than with volcanogenic parent material. Therefore, it is likely that the zeolites observed in the CTBE interval formed as an alteration product of biogenic silica (see also Thurow, this volume) and not as an alteration product of volcanic glass.

\section{ORGANIC GEOCHEMISTRY}

Dark-colored layers with relatively high concentrations of organic matter have been found in numerous oceanic locations in Cretaceous rocks, as well as in numerous onshore sections. The distribution of such occurrences in the North Atlantic Ocean is discussed by Arthur (1979a, 1979b), Waples (1983), Herbin et al. (1986b), Meyers et al. (1984), and Stein et al. (1986) among others, with the intent of identifying the paleoceanographic factors involved in the formation of these unusual strata, commonly called black shales. Improved preservation of organic matter, increased contribution of continental organic matter to oceanic basins, and the enhanced production of marine organic matter are some of the factors that have been suggested to affect the character of the organic content of the black shales. Investigations of the type of organic matter in North Atlantic Cretaceous sediments are summarized by Summerhayes (1981), Katz and Pheifer (1983), and de Graciansky et al. (1982). Varying proportions of marine and terrigenous organic constituents are found in sediments deposited at different times and locations in the Cretaceous Atlantic Ocean, but the CTBE black shales in the North Atlantic are always characterized by marine organic matter, as are occurrences in the different paleobathymetric realms in the western Tethys (Herbin et al., 1986b; Thurow, 1987) and South Atlantic (Herbin et al., 1986b; Meyers, 1986). Comparison of the black shales' organic matter to that of the adjacent organic-carbon-poor lithologies further contributes to our understanding of the formation of the black shales (Dunham et al., 1987).

\section{Organic Carbon and Organic Matter $\mathbf{C} / \mathbf{N}$ Ratios}

Sixty-six sediment samples were taken at Site 641 for organic carbon determination using the Perkin-Elmer elemental analyzer. Atomic $\mathrm{C} / \mathrm{N}$ ratios of organic matter were determined for only two samples (compare with Dunham et al., this volume). The organic carbon percentage determined on dry-sediment weight and the percentage of carbonate vs. depth for 15 samples from Hole 641A is plotted in Figure 6, with values listed in Table 2.

From 15.7 to 53.6 mbsf (Units A and B), preservation of organic matter is poor, averaging $0.12 \%$, which is below the $0.3 \%$ average for ancient deep-ocean sediments (McIver, 1975). There is no difference between Units A and B with respect to organic carbon, which denies the hypothesis that Unit B is a leached part of the Unit C. The black claystone of Unit C (53.6 to 53.9 mbsf) averages $10.7 \%$ organic carbon. From 53.9 mbsf to the bottom of Hole 641A (Units D and E), preservation is again poor, with the lowest values occurring immediately below Unit C (average $0.22 \%$ total organic carbon in Unit D). Exceptions occur in two intervals in Unit E, with $1.94 \%$ (Sample 103-641A$7 \mathrm{X}-1,6-7 \mathrm{~cm}$ ) and $3.05 \%$ total organic carbon (Sample 103$641 \mathrm{~A}-7 \mathrm{X}-5,10-15 \mathrm{~cm}$ ). The organic carbon and carbonate determinations from Site 641 are plotted in Figure 6 for comparison. 

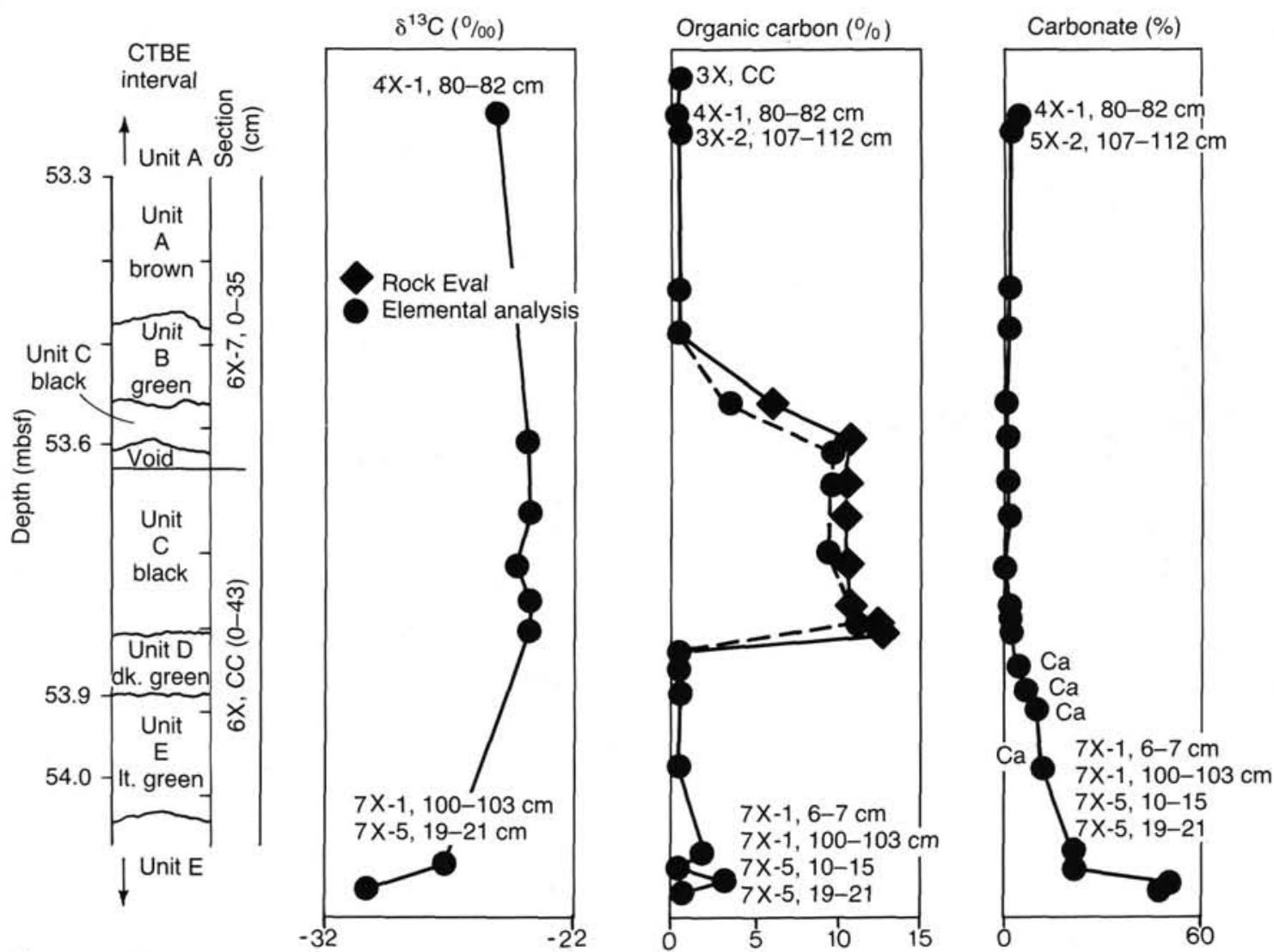

Figure 6. Lithologic units, carbon isotopes, organic carbon, and carbonate values from the CTBE interval at Hole 641A.

Atomic $\mathrm{C} / \mathrm{N}$ ratios were determined for two samples. Sample 103-641A-6X, CC $(20 \mathrm{~cm})$, from the Unit $C$ black shale has a $\mathrm{C} / \mathrm{N}$ ratio of 23 , whereas Sample 103-641A-6X, CC (31-34 $\mathrm{cm})$, from the Unit $\mathrm{E}$ green claystone has a $\mathrm{C} / \mathrm{N}$ ratio of 9 . The $\mathrm{C} / \mathrm{N}$ values are related to the organic carbon concentrations of the samples (Table 2). These differences parallel those found in equivalent lithologies at Site 603 on the outer Hatteras Rise (Dunham et al., 1987).

\section{Rock-Eval Analysis}

Thirty-seven samples of the Site 641 green and black claystones, including eight samples from around the CTBE, were analyzed using the Rock Eval. The results are listed in Table 2 and plotted as hydrogen index vs. oxygen index in Figure 7. Organic matter from land plants is usually rich in woody tissues and hence has higher Rock-Eval oxygen indices and lower hydrogen indices than those found in more lipid-rich marine matter from algal production.

The organic matter of the CTBE is composed of marine matter (kerogen type II). The average hydrogen index is 500 , and the average oxygen index is 27 . These values are typical of those associated with marine organic matter, and they contrast strongly with values from the Albian black shales at this site (Fig. 8).

The temperature of the S2 peak maximum $\left(\mathrm{T}_{\max }\right)$ is an indicator of the maturation of the organic matter (Espitalié et al., 1977). $T_{\max }$ values for the CTBE average $406^{\circ} \mathrm{C}$ (Table 2). This low value indicates a low-temperature thermal history for the preserved kerogen because the organic matter is immature.

\section{Comparison with Site 398}

Site 398 documents a continuous record of middle Cretaceous anoxia. The CTBE is not reflected by a single black shale layer but by an alternation of gray, dark, and red claystones with some true black shale layers and even some detrital layers (Pl. 4, Figs. 1 and 2). The CTBE interval was detected in Sections 1 and 2 of Core 398D-56. The Cenomanian/Turonian boundary is fixed at Sample 398D-56-2, $122 \mathrm{~cm}$, by palynomorphs (Masure, 1984) and at Sample 398D-56-2, 98-102 cm, by radiolarians (Thurow, this volume). The organic geochemistry of Cretaceous organic-rich sediments is provided by Deroo et al. (1979) and Arthur (1979b).

A detailed sampling of Sections 2 to 5 of Core 398D-56 was made by Herbin et al. (1986b) to characterize the CTBE. In the thin black levels of Sections 398D-3 through 398D-5 (Unit E at Site 641 ), the total organic carbon values are less than $3.5 \%$, and usually near $1.5 \%$. This organic matter, which is common in the black shales of the Hatteras Formation, is kerogen type III, with a hydrogen index ranging between 50 and $150 \mathrm{mg} \mathrm{HC}$ (hydrous carbon)/g TOC (total organic carbon). These values are comparable to those measured at Hole $641 \mathrm{C}$ for the equivalent time interval. The interbedded greenish claystones contain $0.1 \%-0.3 \%$ total organic carbon. In Section 398D-2, the CTBE interval (Units B-D at Site 641), the laminated dark gray to grayish black claystones are rich in total organic carbon $(2.5 \%$ $13 \%$ ). The organic matter is a mixture of types II and III, and the richer levels have hydrogen indices ranging from $200-380 \mathrm{mg}$ $\mathrm{HC} / \mathrm{g} \mathrm{TOC}$, which are comparable, but lower, than those at Site 641. The upper contact with the Plantagenet Formation (Unit A at Site 641) is clearly marked in Sample 398D-56-2, $19 \mathrm{~cm}$, with the beginning of the brownish zeolitic mudstones and claystones that are almost devoid of organic carbon $(0.1 \%)$.

\section{ORGANIC CARBON ISOTOPES}

Recent studies have confirmed the existence of secular changes in $\delta^{13} \mathrm{C}$ values of carbonate and organic carbon. Compilations 


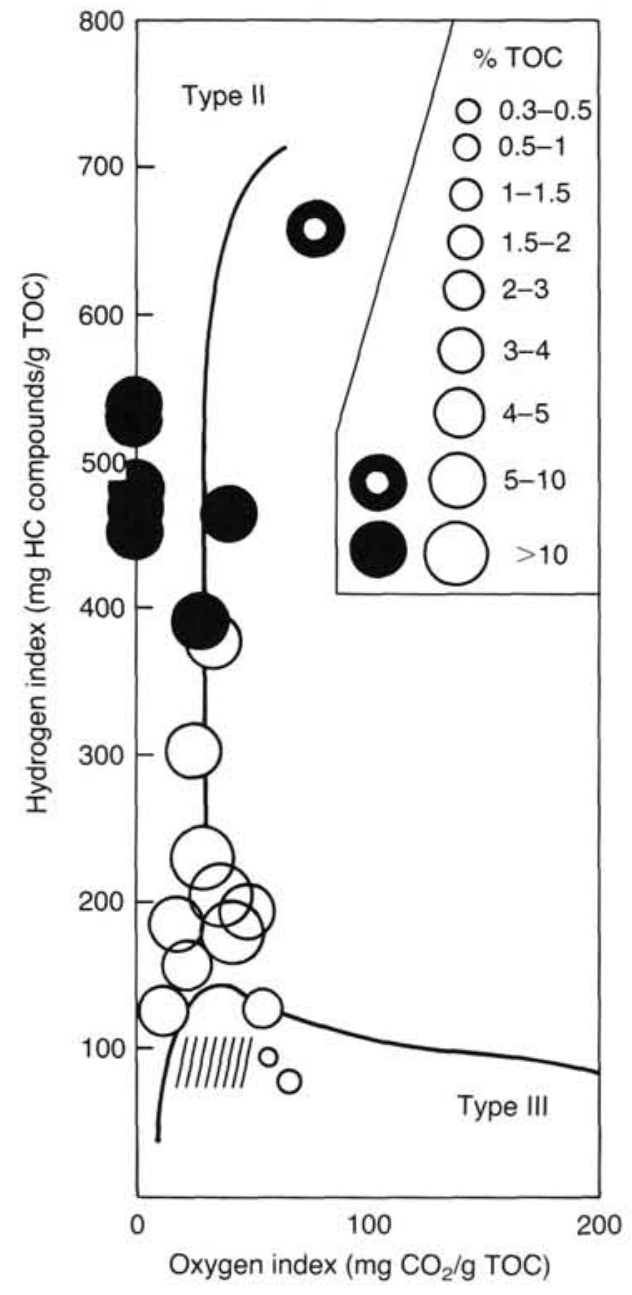

- Hole 641A-Unit C

- Hole 398D-Core 56-2

IIIII Hole 641C-Aptian/Albian samples

Figure 7. Results of Rock-Eval analyses for the CTBE interval at Holes 398D and 641A. Rock-Eval data of the Aptian/Albian black shales from Hole $641 \mathrm{C}$ are plotted for comparison (data from Herbin et al., 1986a).

of isotopic data from Mesozoic rocks generally show parallel trends in $\delta^{13} \mathrm{C}$ values of both carbonate and organic matter, with several gradual secular shifts of $1 \%_{0}-2 \%_{0}$ (Fischer and Arthur, 1977; Kroopnick et al., 1977; Veizer et al., 1980; Hoefs, 1981). Abrupt secular excursions of $+3 \%$ to $+4 \%_{0}$ were reported from the Lower Cretaceous (Scholle and Arthur, 1980) and lower Upper Cretaceous (CTBE; Scholle and Arthur, 1980; Pratt and Threlkeld, 1984; Dean et al., 1986; Schlanger et al., 1987). The CTBE, as described in this paper, now appears to confirm earlier interpretations of the $\delta^{13} \mathrm{C}$ shift. This $\delta^{13} \mathrm{C}$ excursion is a valuable stratigraphic marker, as shown by Scholle and Arthur (1980), because it resulted from a geologically brief, global geochemical event (see organic geochemistry discussion) and because it can be readily distinguished from other isotopic events by its distinct uniform character in quite different paleosettings. However, all data available are from sediments deposited in comparably shallow water, some of which do not contain the characteristic black shale band; thus, the data set does not represent the total variety of oceanic paleosettings.

To determine whether or not a $\delta^{13} \mathrm{C}$ excursion is also detectable in deep-sea organic carbon, we measured the organic mat- ter of eight samples from Site 641, including all CTBE-related sediments, for $\delta^{13} \mathrm{C}$ (Fig. 6 and Table 2).

\section{Results}

The isotopic composition of the organic matter clearly records a positive excursion of $5 \%$ spanning the CTBE, a result similar to that at the other CTBE intervals previously described by the authors. Furthermore, this positive spike is in accordance with the base of the Whiteinella archaeocretacea foraminiferal zone (Fig. 9).

The positive shift in Unit E is very prominent, whereas the back shift in Unit A is small, probably because of the lack of close-spaced sample intervals.

The occurrence of the CTBE in widely separate localities from which large collections of isotopic data are available (Scholle and Arthur 1980; Pomerol, 1983; Pratt and Threlkeld, 1984; Hilbrecht and Hoefs, 1986; Schlanger et al., 1987) provides an excellent opportunity to document a global isotopic event. Worldwide changes in $\delta^{13} \mathrm{C}$ reflect alternations in the carbon cycle. However, such strong positive excursions are not fully understood. Presumably the shift toward heavier $\delta^{13} \mathrm{C}$ values was the result of increased withdrawal of isotopically light organic matter because of the deposition of organic-carbon-rich black shales (Pratt and Threlkeld, 1984), rather than an effect of enhanced preservation or high production of organic matter. This interpretation was favored by Scholle and Arthur (1980), who first described the $\delta^{13} \mathrm{C}$ spike at the Cenomanian/Turonian boundary. They explained the high $\delta^{13} \mathrm{C}$ values in pelagic and shelf limestones, which were deposited contemporaneously with organic-rich layers, as the result of burial of large amounts of marine organic carbon, rich in ${ }^{12} \mathrm{C}$. Consequently, an enrichment of ${ }^{13} \mathrm{C}$ in the ocean surface waters occurred, and this is reflected in the high $\delta^{13} \mathrm{C}$ of both the pelagic and shelf limestones deposited during the CTBE. Recently, Schlanger et al. (1987) provided a set of carbonate $\delta^{13} \mathrm{C}$ values from several globally distributed CTBE sequences from different paleosettings that clearly demonstrate a positive excursion in the studied sections (Cenomanian/Turonian positive $\delta^{13} \mathrm{C}$ spike). These authors also interpret this spike as resulting from the preservation in black shale of large amounts of ${ }^{12} \mathrm{C}$, which were not recycled.

In the classical, "high-productivity" CTBE location at the northwest African Tarfaya Basin (Fig. 16) (Einsele and Wiedmann, 1982; Wiedmann et al., 1982; Leine, 1986), a similar $\delta^{13} \mathrm{C}$ pattern was detected (Fig. 9; Thurow, unpubl. data). The studied sequence contains $200 \mathrm{~m}$ of upper Cenomanian to upper Turonian laminated calcareous black shales deposited under upwelling conditions in a moderately deep (approximately 200 $300 \mathrm{~m}$ ), but open, marine environment (Kuhnt et al., 1986). The carbon $\delta^{13} \mathrm{C}$ values shift from $-2.85 \%$ in the upper Cenomanian to a maximum of $-24.5 \%$, decreasing again in the middle to upper Turonian (Fig. 9).

As the organic matter and pelagic carbonate were produced in the ${ }^{12} \mathrm{C}$-depleted zone of the oceanic surface water, the positive $\delta^{13} \mathrm{C}$ excursion is found in both fractions of the sediment. This fact allows comparison of the $\delta^{13} \mathrm{C}$ curves determined for organic substance with those determined for the carbonate, because the positive excursion is always distinct (Fig. 9).

Analysis of closer spaced samples from distinct deep-water CTBE intervals (compare with Fig. 16) is needed to confirm the Site 641 data. In summary, if the $\delta^{13} \mathrm{C}$ shift confirmed at several sites can be proven to be time consistent, it could be correlated and used as a global marker for the CTBE. This method would be independent of both the paleosetting and different approaches to performing biostratigraphic zonations.

\section{INORGANIC GEOCHEMISTRY}

Cretaceous black shales from the Atlantic Ocean are known for their unusual trace metal content (Lange et al., 1977; Brum- 


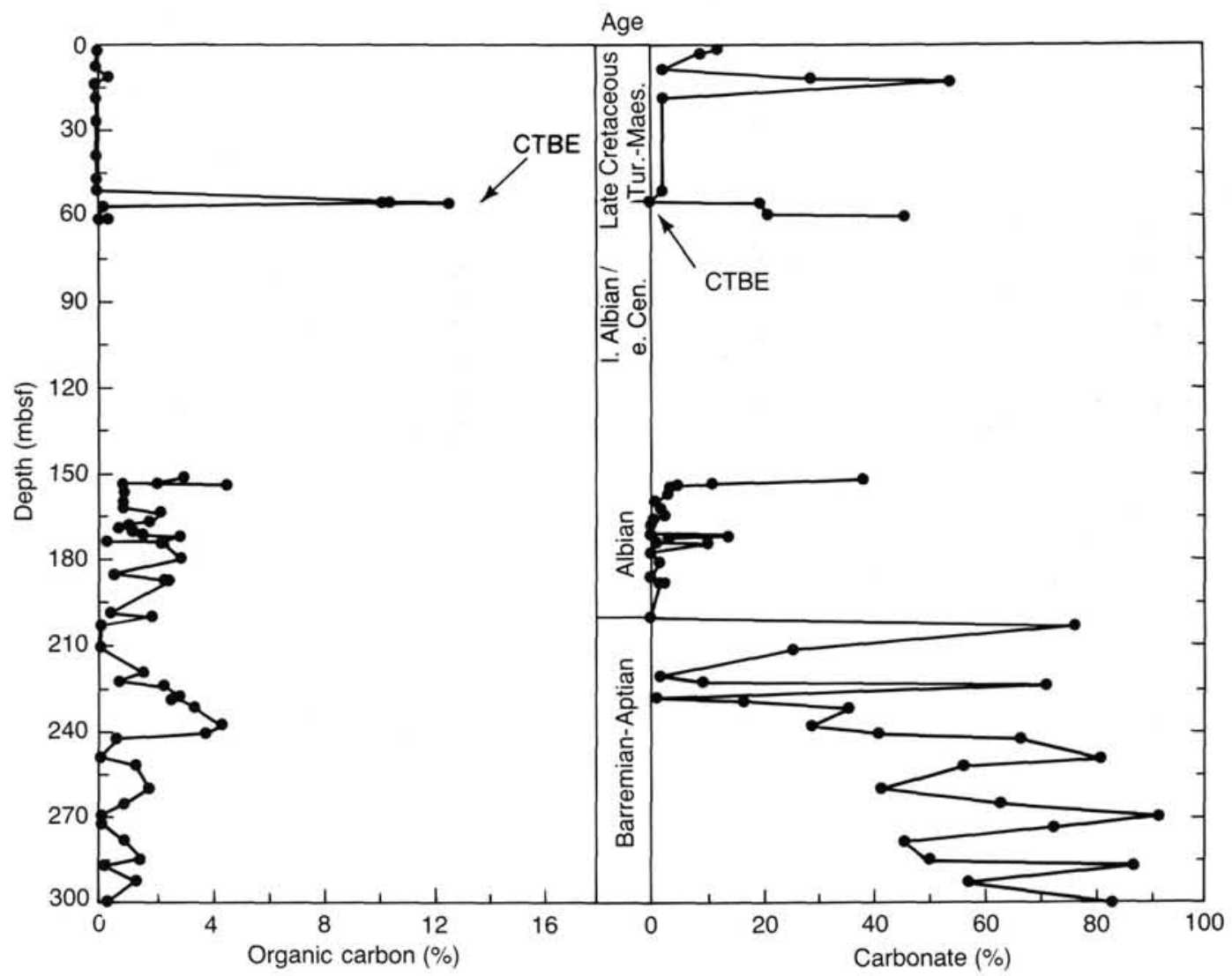

Figure 8. Variations in organic carbon content and carbonate from the middle Cretaceous section at Site 641.

sack, 1980; Dean et al., 1984). The accumulation of specific trace metals in organic-carbon-rich sediments may be understood only in terms of the relatively well-known behavior of these elements in the marine environment.

Reliable data for many trace metals in seawater and marine biota have been generated only within the last decade (Martin and Knauer, 1973; Boyle et al., 1976; Bruland, 1980; Collier and Edmond, 1984). Improvement in the data was made possible through the development of more sensitive analytical techniques and the recognition of contamination problems with conventional sampling methods.

Many trace metals in the marine environment are involved in nutrient-type cycling processes. Elements such as $\mathrm{Cd}$ and $\mathrm{Zn}$ that incorporated into biota during plankton growth in the photic zone are regenerated at depth when decaying plankton remains settle through the oxygen-containing water column. Sediments deposited at greater water depths are therefore rarely enriched in nutrient-like elements from bioaccumulation processes. On the other hand, sediments underlying areas of high biological productivity (e.g., diatomaceous muds) at or close to continental margins exhibit a distinct chemical imprint on major and minor element abundances. The chemistry of this type of sediment seems to reflect the processes of metal uptake and release occurring in the overlying water column (Brumsack, 1986). Labile nutrients ( $C, N$, and $P$ ) and associated trace metals (e.g., Ag and Cd) accumulate in lesser amounts in upwelling sediments than would be expected from plankton metal data, because these elements are regenerated to a large degree in the water column. In contrast to this, other nutrients (such as $\mathrm{Si}$ ) and metals (e.g., Ba) are more resistant to dissolution and therefore enter this sediment type in higher proportions. It is important to note that under the present oxic to partly suboxic condi- tions in the oceans, trace metals are rarely found enriched to high levels in upwelling sediments rich in organic carbon.

We discuss the accumulation and concentration of certain major and minor elements in view of the preceding findings and try to extract some information about the paleoenvironmental conditions during the deposition of the CTBE black shale layer at Site 641 .

\section{ANALYTICAL METHODS}

Splits $(100 \mathrm{mg})$ of the powdered samples (agate mortar) were digested at $180^{\circ} \mathrm{C}$ in PTFE pressure digestion autoclaves (PDS-6; Heinrichs et al., 1986) with a mixture of purified acids, consisting of $3 \mathrm{~mL} \mathrm{HF}, 3 \mathrm{~mL}$ $\mathrm{HClO}_{4}$, and 1 to $3 \mathrm{~mL} \mathrm{HNO}_{3}$ (depending on total organic carbon content). The digests were evaporated to dryness and completely redissolved in $0.5 \mathrm{~mL} \mathrm{HNO}_{3}$ before dilution to a final volume of $50 \mathrm{~mL}$ with deionized water (dilution factor 500). Procedural blanks and international rock standards (SGR-1 and G-2) received the same treatment. The minor elements $\mathrm{Ag}, \mathrm{As}, \mathrm{Cd}, \mathrm{Co}, \mathrm{Cr}, \mathrm{Cu}, \mathrm{Mn}, \mathrm{Mo}, \mathrm{Ni}, \mathrm{Pb}, \mathrm{Sb}, \mathrm{Tl}$, and $\mathrm{Zn}$, as well as the major elements $\mathrm{Fe}, \mathrm{K}$, and $\mathrm{Na}$, were determined from the acid digests by flame atomic absorption spectrophotometry (AA) (K and $\mathrm{Na}$ in the emission mode) and graphite tube AA (Perkin-Elmer 4000 atomic absorption spectrophotometer equipped with a HGA-500 graphite tube). For the determination of $\mathrm{Ag}, \mathrm{Cd}, \mathrm{Pb}$, and Tl, a 1000-ppm $\left(\mathrm{NH}_{4}\right)_{2} \mathrm{HPO}_{4}$ solution was added for matrix modification. La-nitrate (1000 ppm) was added to reduce memory effects in the determination of Mo. A 1000ppm Ni solution stabilized $\mathrm{Sb}$ and As during the ashing step. The accuracy of the flameless AA determinations is usually better than $10 \%$ (relative) except for very low concentrations close to the detection limit. The accuracy for flame AA determinations is better than 3\% (relative).

The elements $\mathrm{Ba}, \mathrm{Cr}, \mathrm{Sr}, \mathrm{V}, \mathrm{Al}, \mathrm{Ca}$, and $\mathrm{Mg}$ (as well as $\mathrm{Mo}$ in higher concentration levels) were determined by inductively coupled, argon plasma emission spectrometry (ICP-AES) (ARL 35000 ICP). The precision checked by analyzing SGR-1 and G-2 was usually better than $5 \%$ (relative). Major elements ( $\mathrm{Al}, \mathrm{Si}, \mathrm{Ti}$, and $\mathrm{P}$ ) were determined by ICPAES from borate fusion solutions (100-mg sample and 400-mg $\mathrm{LiBO}_{2}$ 

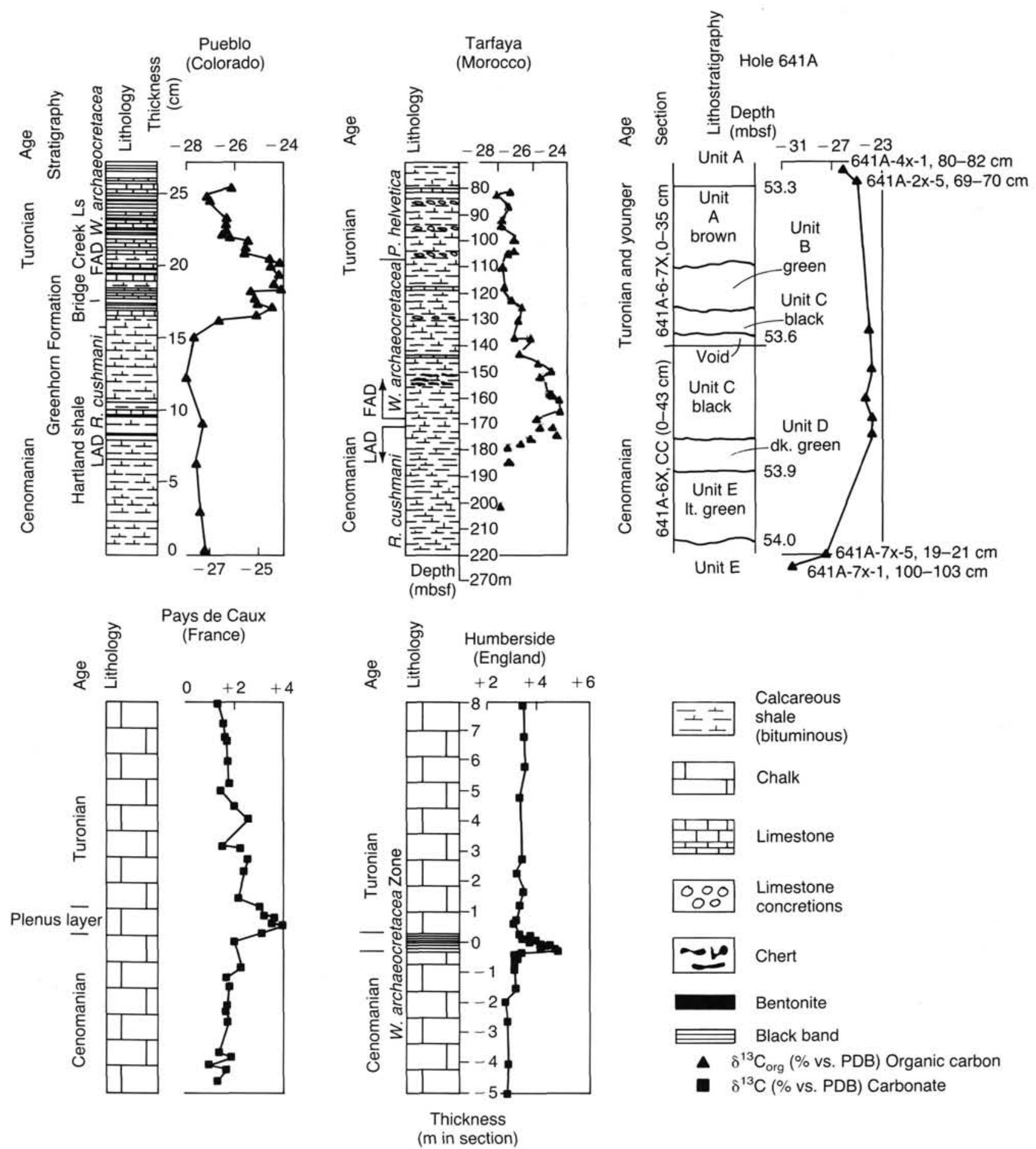

$$
\text { ( } m \text { in section) }
$$

Figure 9. Isotopic correlation of selected onshore locations with distinct expressions of the CTBE in comparison with carbon isotope data for the CTBE interval at Site 641. Section data: Pueblo (Pratt and Threlkeld, 1984; Leckie, 1985), Tarfaya (Thurow, unpubl. data; biostratigraphy from Kuhnt et al., 1986), Pays de Caux (Pomerol, 1983), Humberside (Schlanger et al., 1987; biostratigraphy from Hart and Bigg, 1981).

dissolved in $0.75 \mathrm{~N} \mathrm{HCl}$ and made up to a final volume of $100 \mathrm{~mL}$ ) when only a small quantity of the sample was available. X-ray fluorescence spectrometry (XRF) (ARL 72000 Quantometer) was used for determinations from samples of sufficient size.

$\mathrm{Co}, \mathrm{Rb}, \mathrm{Sb}, \mathrm{Sc}, \mathrm{Th}, \mathrm{U}, \mathrm{Na}$, and some rare earth elements were determined by instrumental neutron activation analysis (INAA). Standard G-2 (spiked with 10-ppm Sb) served as calibration standard.

$\mathrm{S}$ and $\mathrm{C}$ ( $\mathrm{TOC}$ and mineral $\mathrm{CO}_{2}$ ) were analyzed by coulometric titration following combustion in an oxygen atmosphere (Herrmann and Knake, 1973; Lange and Brumsack, 1977).
Some elements were determined by more than one method. Agreement was generally better than $10 \%$ (relative) for trace metals and 5\% (relative) for major elements.

\section{Results}

The concentration profiles of the investigated elements are presented in Figure 10, and the individual data are tabulated in the Appendix A. In addition to samples from the organic-carbon-rich black shale layer, samples from above and below the 


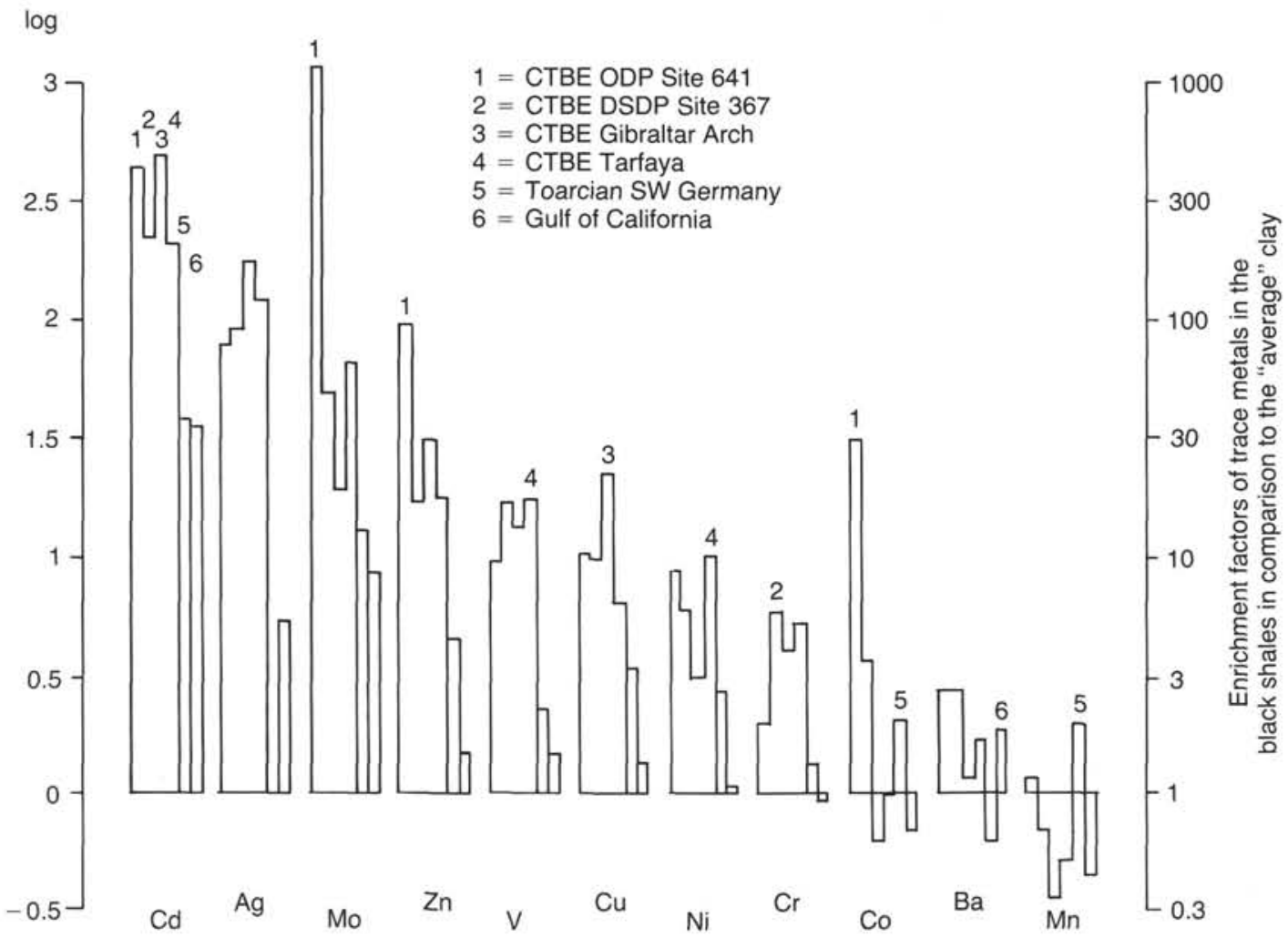

Figure 10. Enrichment of trace elements in the CTBE black shales and other organic-carbon-rich sediments.

layer were also analyzed. The black shale samples are plotted according to their position in the core in Figure 11.

Most major elements ( $\mathrm{Al}, \mathrm{Si}, \mathrm{Mg}$, and $\mathrm{Ti})$ are present in slightly lower concentrations in the black band because of dilution by organic matter. This does not seem to be the case for $\mathrm{K}$ and $\mathrm{Na}$. The $\mathrm{Ca}$ content increases below the black shale, reflecting the lithologic change from deep-sea clays to carbonates at this level. Total organic carbon and S are considerably enriched in the black shale, and $\mathrm{Fe}$ is mostly present as pyrite. $\mathrm{Mn}$ is depleted due to reductive mobilization. Except for one value at the base of the organic-carbon-rich section, the P content is not unusually high. The trace metals may be divided into several groups:

1. Elements that are predominantly terrigenous in origin and therefore, reflect abundant alumosilicates. These include $\mathrm{Rb}$, Cs, Sc, Hf, Th, and the rare earth elements.

2. Elements that are considerably enriched in the black shale layer and seem to be associated with enrichments of total organic carbon or/and $\mathrm{S}$, including $\mathrm{Ag}, \mathrm{Cd}, \mathrm{Zn}, \mathrm{Sb}, \mathrm{Tl}, \mathrm{V}, \mathrm{Mo}$, $\mathrm{Cu}, \mathrm{Ni}, \mathrm{Co}, \mathrm{U}, \mathrm{Pb}$, and As.

3. Elements that are associated with both phases, terrigenous and enrichments of total organic carbon or S, to about the same extent, including $\mathrm{Cr}$ and $\mathrm{Ba}$.

4. $\mathrm{Sr}$, which correlates with carbonate.

Surprisingly, the maximum concentrations of those elements listed in the second group are not necessarily found at the same position within the black layer. For example, $\mathrm{Ag}, \mathrm{Cd}, \mathrm{Sb}, \mathrm{V}, \mathrm{Cu}$, and $\mathrm{Pb}$ are concentrated in the upper part, whereas $\mathrm{Zn}, \mathrm{Tl}$, and Mo are more abundant in the central part and at the bottom of the black shale band. $\mathrm{Ni}, \mathrm{Co}$, and $\mathrm{U}$ concentrations are high throughout the entire total-organic-carbon- and S-rich layer.

\section{Discussion}

Black shale layers with chemical characteristics similar to the CTBE interval at Site 641 seem to be widespread, at least in the Cretaceous Atlantic and Tethys oceans (Brumsack, 1980; Dean et al., 1984; Brumsack and Thurow, 1986). But do these specific trace metal enrichments in black shales provide information with respect to the paleoenvironmental conditions during black shale deposition, or are these enrichments only diagenetic in origin?

As previously mentioned in our introduction, any interpretation of the trace metal chemistry of organic-carbon-rich sediments has to consider the behavior of these elements in the present-day marine environment. Sediments rich in organic carbon are deposited in the modern oceans only where biological production in the waters is high, sediment-accumulation rates and concomitant burial rates are high (e.g., upwelling areas), or preservation of organic matter in the water column is extremely good (anoxic basins, such as the Black Sea).

In addition to nutrients, marine biota accumulates several trace metals during growth. This fact is reflected in the low concentration ranges found for several elements, (e.g., $\mathrm{Cd}$ and $\mathrm{Zn}$ ) in the surface ocean (see compilation by Bruland, 1980). On the other hand, plankton do not seem to accumulate these elements to high enough levels to be able to explain the trace metal content of black shales by rapid deposition of this unaltered material. Some elements found enriched in CTBE black shales are considerably enriched in plankton (e.g., $\mathrm{Zn}, \mathrm{Ba}, \mathrm{Cd}$, or $\mathrm{Cu}$ ), whereas the elements $\mathrm{V}, \mathrm{Mo}$, and $\mathrm{Tl}$ are present in only trace amounts in marine biota but are enriched in black shales. In consideration that under present-day conditions in the oceans elements are involved in nutrient-type cycling processes and, therefore, are regenerated within the water column, plankton as the only source for metals in the black shales seems highly unlikely. 


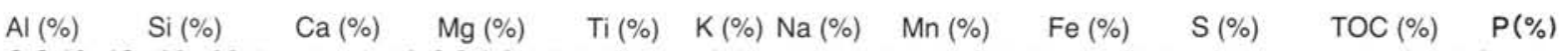

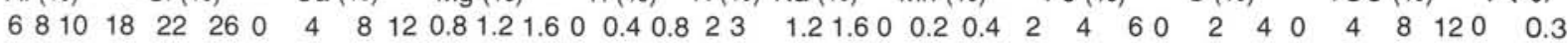

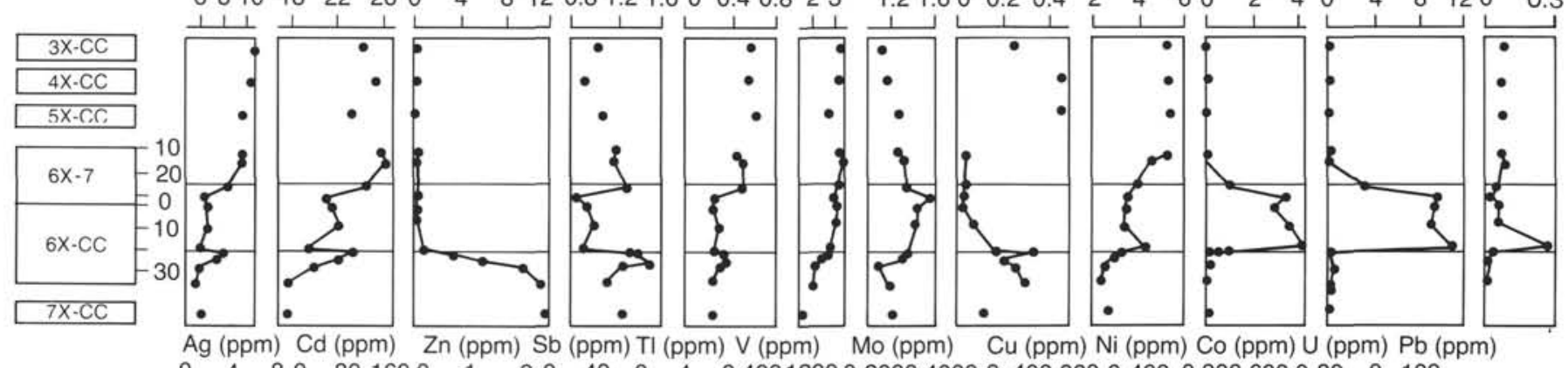

Ag (ppm) Cd (ppm) Zn (ppm) Sb (ppm) Tl (ppm) V (ppm) Mo (ppm) Cu (ppm) Ni (ppm) Co (ppm) U (ppm) Pb (ppm)

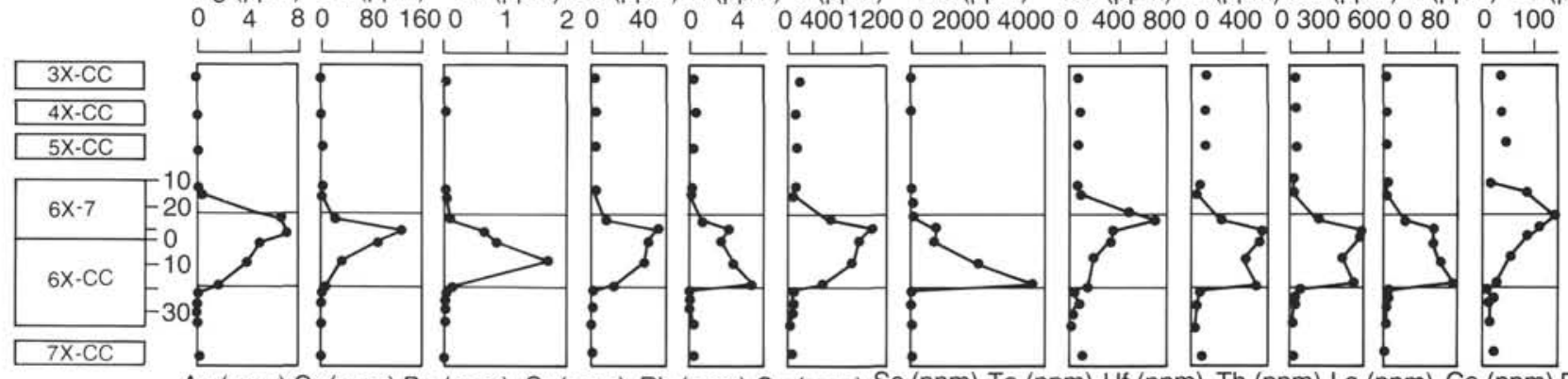

As (ppm) Cr (ppm) Ba (ppm) Sr (ppm) Rb (ppm) Ca (ppm) Sc (ppm) Ta (ppm) Hf (ppm) Th (ppm) La (ppm) Ce (ppm) Eu (ppm)

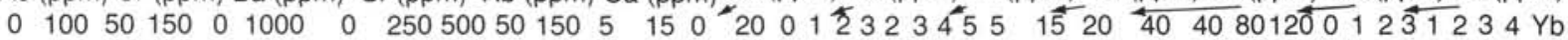
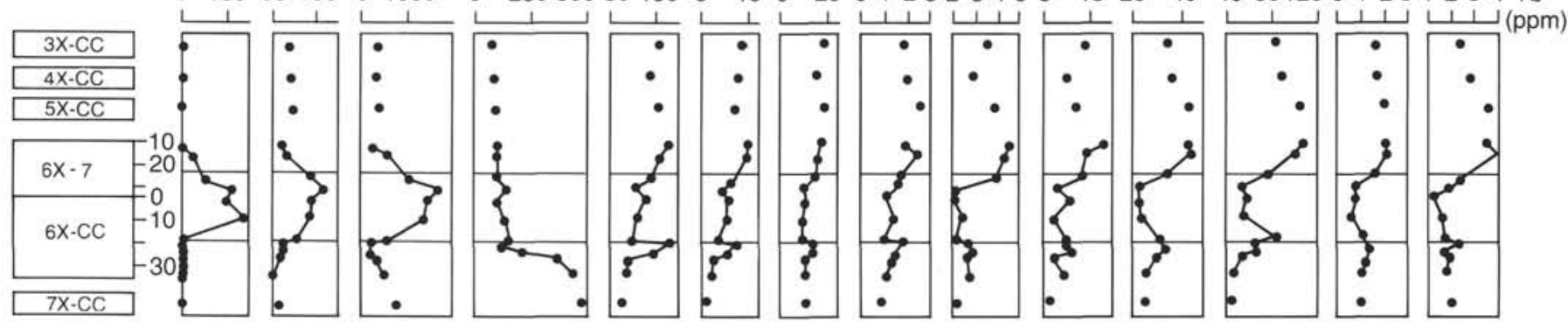

Figure 11. Major and minor element geochemistry of the CTBE black shales at ODP Hole 641A.

Upwelling sediments are usually mixtures of terrigenous components with plankton material that survived transit through the oxic or suboxic water column to be rapidly buried. But only a small fraction of the labile elements (e.g., Cd) enters the sedimentary column, as opposed to elements, which are regenerated at greater water depths (e.g., Ba) (Brumsack, 1986). For other elements, such as Mo, V, and possibly $\mathrm{U}$, that, to a certain extent, enter these sediments directly from the overlying water column, the contribution from plankton is small. The reduced species are at least partly associated with organic matter, even in the pore waters (Brumsack and Gieskes, 1983). The CTBE black shales are generally extremely enriched in both types of elements.

The following processes may be responsible for the trace metal enrichment in the black shale layer: (1) diagenetic remobilization and fixation processes within the sedimentary column and (2) preservation of marine organic matter in an oxygen-free environment (like the Black Sea), with a significant contribution of metals from the water column.

Diagenetic mobilization is evident for Mn, which is easily depleted in reducing sediments by diffusion into adjacent layers or the water column. The high Mn concentrations in the carbonates underlying the black shale band demonstrate this fact. A halo of reduced green sediments is commonly reported (Dean and Gardner, 1982; Dean et al. 1984) from above and below black shale layers. Elements that originally were fixed in these sediments in Fe- or Mn-oxide/hydroxide coatings may diffuse into the organic-carbon-rich layer and become trapped. Field evidence suggests that most of the reduction halos are restricted to several decimeters below and above a black shale layer. By a simple mass-balance calculation, it seems possible that from the elements presented here, only $\mathrm{Cr}$, and to a lesser extent $\mathrm{Pb}, \mathrm{Tl}$, $\mathrm{Ni}$, and $\mathrm{Co}$, may become enriched in the black band as a result of remobilization. The extreme accumulations of $\mathrm{Mo}, \mathrm{Cd}, \mathrm{Zn}$, $\mathrm{V}$, and $\mathrm{Ag}$ must be the result of other processes, unless the under- or overlying sediments had an unusual chemical composition. Analysis of samples from the more distant Sections 103641A-3X, CC, to 103-641A-5X, CC, and 103-641A-7X, CC, indicates that these sediments are comparable to normal deep-sea clays and marls. Therefore, it does not seem justifiable to assume an exclusive diagenetic origin for the metal enrichments encountered in the black shale layer.

If diagenetic processes cannot explain the unusual composition of the black shale, then these enrichments are due to processes during sedimentation and may give information about the environment of deposition during the CTBE. Long periods of time are required to accumulate trace metals from the water column, because seawater concentrations are very low. Furthermore, the preservation of organic matter in the water column has to be enhanced by orders of magnitude, in comparison to present-day conditions in the open ocean. The most likely conditions favoring the accumulation of organic carbon in the sedi- 
ments (and water column) at very low accumulation rates should be similar to those in the present-day Black Sea. An anoxic water column would be an ideal trap for redox-sensitive and sulfide-forming trace metals.

Recently, Jacobs et al. (1978) showed that trace metals are removed from seawater as a result of precipitation of sulfides in the anoxic water column of the Cariaco Trench. A high trace metal load of particulates from the anoxic zone of the Black Sea is attributed to sulfide precipitation processes by Spencer et al. (1972). Unfortunately, because sedimentation rates are quite high in the Black Sea (Manheim and Chan, 1974), a significant metal contribution from the water column is not well evidenced in the sediment chemistry, except for Mo and U (Rona and Joensu, 1974). Preliminary data on reanalyzed Black Sea sediments indicate only slight, but significant, enrichment of many trace metals. This enrichment seems to be compatible with the overall metal input through rivers and the inflow of Mediterranean seawater (Brumsack, 1988). Therefore, a Black Sea type of environment-but with a drastically reduced sedimentation ratemay be the best explanation for the black band encountered at Site 641 .

A simple balance calculation provides some further arguments in favor of such an environment. The weighted mean Mo concentration in the black shale layer amounts to $2300 \mathrm{ppm}$. Asssuming a layer thickness of $30 \mathrm{~cm}$, a porosity of $50 \%$, and a density of $2 \mathrm{~g} / \mathrm{cm}^{3}, 30 \mathrm{~g} / \mathrm{cm}^{2}$ sediment would have been deposited, which is equivalent to $69 \mathrm{mg} / \mathrm{cm}^{2} \mathrm{Mo}$. From the Mo concentration in modern seawater of $11 \mathrm{ppb}$ (Collier, 1985), a 63km-long water column would have had to be completely stripped for its Mo content. This is probably a low estimate, in consideration of the reduced Mo values (although not to zero) found in the Black Sea water column. According to Pilipchuk and Volkov (1974), the difference in Mo content between surface (oxic) and deep (anoxic) waters in the Black Sea is only $2 \mathrm{ppb}$. At a water exchange rate between the reservoirs of $1.7 \mathrm{~m} / \mathrm{yr}$ (Fonselius, 1974), at least 200,000 yr would have been required to accumulate the Mo content of the black shale at Site 641 under similar conditions. The sediment-accumulation rate therefore must have been very low $(<0.2 \mathrm{~cm} / 1000 \mathrm{yr})$. Preliminary data on the distribution of $U^{238}$ and $U^{234}$ in the black band indicate that the uranium has a seawater origin. The $U$ distribution within the black band seems to be comparable to the Mediterranean sapropels (Mangini and Dominik, 1979), except for the higher $U$ concentrations, which indicates even lower sedimentation rates. This evidence seems to be compatible with a seawater origin for many of the trace metals reported here, especially $\mathrm{Mo}, \mathrm{V}, \mathrm{Cd}, \mathrm{Ag}$, and $\mathrm{Zn}$.

Neutron activation analysis did not find Ir enriched in the CTBE interval, with values generally below the detection limit (5 ppb).

\section{BIOSTRATIGRAPHY}

The lack of a high-resolution biostratigraphy and the poor correlation and calibration between the different fossil groups are major problems that have affected earlier study, and thus discrimination, of the CTBE. Only in rare cases, especially in some of the shallow-water sections (e.g., the northwest African coastal basins and the United States Western Interior Basin), was it possible to prove the occurrence of prominent black shale deposition accompanied by a major faunal change around the Cenomanian/Turonian boundary, more precisely coeval with the onset of the Whiteinella archaeocretacea foraminiferal zone (Hart and Bigg, 1981; Kuhnt et al., 1986; Thurow and Kuhnt, 1986; Schlanger et al., 1987). Biostratigraphic resolution is adversely affected because the common faunal groups around the CTBE in Tethyan occurrences (such as calcareous foraminifers, radiolarians and benthic foraminifers) are calibrated mainly in low-latitude (Tethyan) pelagic areas, whereas palynomorphs (and nannofossils) are calibrated in Boreal epicontinental areas.

The onset of the CTBE can be defined with the base of the $W$. archaeocretacea foraminiferal zone or, where possible, with the first-appearance datum (FAD) of Crucella cachensis, a distinctive radiolarian species that occurs with the first black shale of the CTBE. This Tethyan datum correlates with the prominent positive $\delta^{13} \mathrm{C}$ shift usually associated with the CTBE (see the black band of the Humberside section in Fig. 9). The FAD of $W$. archaeocretacea defines the base of the $W$. archaeocretacea Zone (partial range zone). This datum level is commonly used as the base of the Turonian in Tethyan areas and marks the onset of the CTBE (Thurow and Kuhnt, 1986). However, in the Pueblo section of the Western Interior Basin, $W$. archaeocretacea has an apparently earlier FAD and co-occurs with Rotalipora cushmani in the upper part of the Hartland Shale member (Leckie, 1985; also see Pueblo section in Fig. 9), which is well before the $\delta^{13} \mathrm{C}$ positive excursion. According to foraminiferal data from Boreal areas, Robaszynski and Caron (1979) placed the base of the $W$. archaeocretacea Zone in the upper part of the Metoicoceras gr. geslinianum ammonite zone. The lower part of this latter zone is coincident with the occurrence of the belemnite Actinocamax plenus (plenus marls, plenus layer). It is not yet known if the FAD of $W$. archaeocretacea in the tropical and Boreal realm is diachronous or if the last-appearance datum (LAD) of $R$. cushmani is not time consistent.

Recent studies of macrofossils in Boreal areas shift the $\mathrm{Ce}$ nomanian/Turonian boundary so far into the Turonian that in palynomorph-calibrated type areas the CTBE is now entirely in the "Cenomanian" (approximately the plenus layer). This is also reflected in the Pays de Caux section (Fig. 9), where the carbon isotope excursion is fixed in the upper Cenomanian plenus marls. This macrofossil-based boundary assignment, however, cannot be traced into the deeper part of the North Atlantic and into the Tethys; thus, it is difficult to correlate although it affects the biostratigraphic results obtained from the different microfossil groups presented in this paper (Fig. 12).

Furthermore, provincialism of macrofossils affects the biostratigraphic resolution. Regional differentiation of Boreal and Tethyan ammonite faunas results in interregional correlation problems at several levels in the mid-Cretaceous and thus affects the calibration of microfossils. These problems are particularly acute around the level of the Cenomanian/Turonian boundary because of the virtual absence of the predominantly Tethyan vascoceratids in Boreal faunas and a similar absence or rarity of key ammonites at critical levels in Tethyan sequences. Microfossil groups are calibrated with regional ammonite zonations; thus, they have also adopted the inconsistency of the macrofossil zonations.

Recently, Lewy et al. (1984) recorded the co-occurrence of typical ammonites for the upper Cenomanian of boreal areas together with lower Turonian index fossils of Tethyan areas. This provides the first evidence for the Cenomanian age of part of the lower Turonian in the Tethys. If confirmed and supported globally by isotopic and trace metal data, this data would enable correlation of all existing macrofossil and microfossil zonations and easy detection of the CTBE at any location.

The biostratigraphic resolution around the CTBE in the North Atlantic sites is poor, either because the depositional environment was below the CCD at this time or because black shale sedimentation provides a microchemical environment unfavorable for the fossilization of calcareous microfossils. Unfortunately, this situation also determines the preservation of siliceous microfossils, including agglutinated foraminifers (which are very rare or absent around the CTBE-probably as a result of the lack of detrital material at this time) and radiolarians (which are commonly altered to zeolite), as well as palynomorphs 


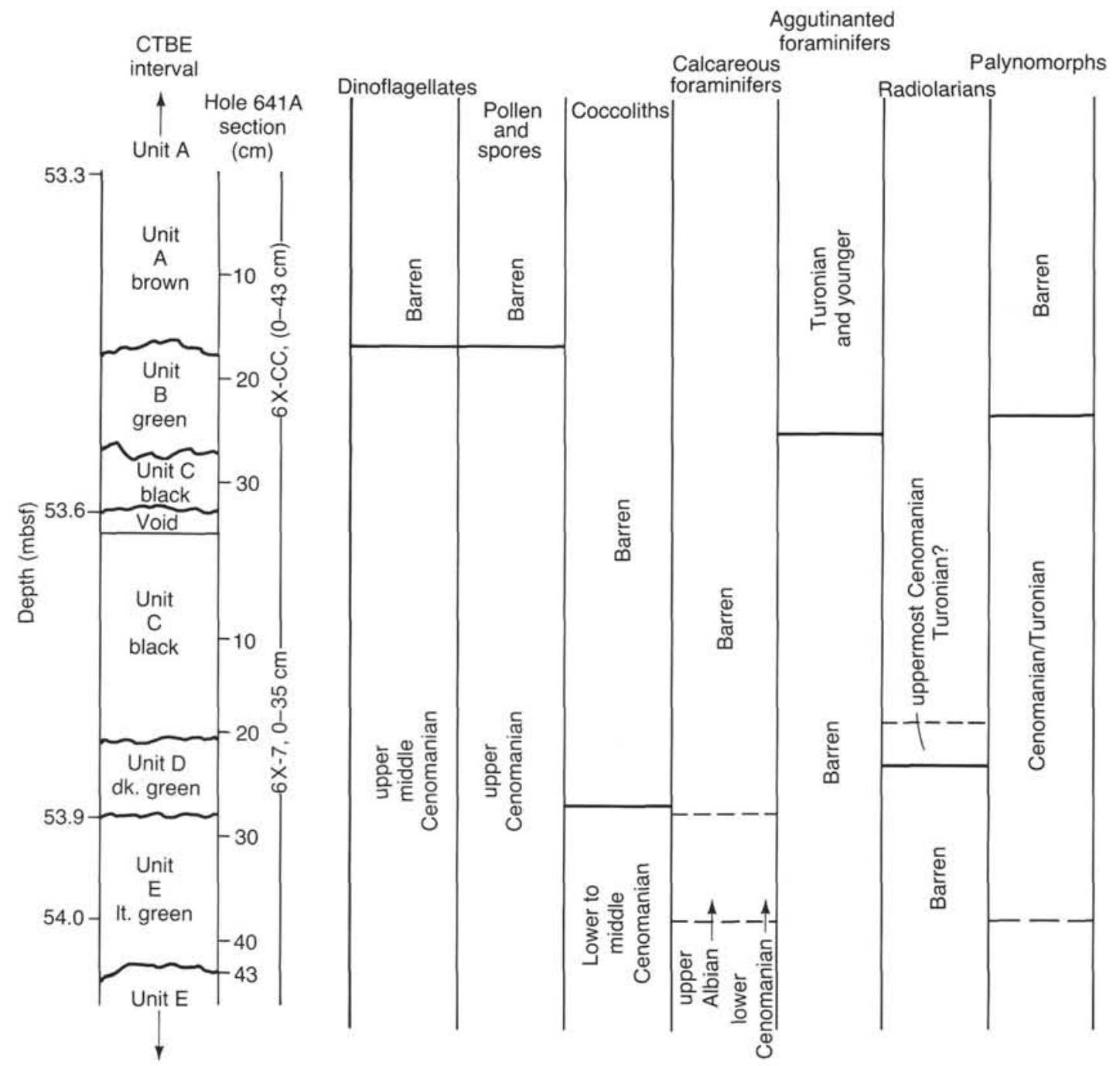

Figure 12. Compilation of biostratigraphic results obtained from the CTBE interval at Site 641. Coccolith data from Applegate and Bergen (this volume) and palynomorph data from Drugg and Habib (this volume).

(which are commonly fragmented). But exceptions exist; the latter two groups provide valuable biostratigraphic data for the CTBE interval at several sites (e.g., Sites 105, 398, 603; Habib, 1977; Masure, 1984; Herbin et al., 1987; Thurow, this volume).

\section{Palynomorphs}

Organic-matter-rich sediment is particularly favorable for palynological investigation because most of the other microfossil groups are usually not well preserved in this type of sediment. Thus, a thorough investigation of dinoflagellates, pollen, and spores has been conducted to date the CTBE sequence accurately at Site 641 .

\section{METHODS}

Thirty samples of dinoflagellates and 38 samples of pollen and spores collected from Hole 641A were processed for palynological examination by standard chemical maceration techniques (Gray, 1965; Sarjeant, 1974), including successive treatments with hydrochloric acid, hydrofluoric acid, and hydrochloric acid again, followed by sieving on nylon sieves (10 $\mu \mathrm{m})$. No potassium hydroxide and no nitric acid were used. The slides were mounted in glycerine jelly.
Pyritization made the correct determination of spores and pollen grains difficult. Two hundred and fifty spores and pollen grains were counted per sample, after which the entire slide was scanned to identify all of the species. A total of 56 species were recovered.

\section{Dinoflagellates}

The five samples collected from below the CTBE, from Samples 103-641A-7X, CC (18-20 cm), to 103-641A-7X-1, 84-86 $\mathrm{cm}$, yielded slightly diversified dinoflagellate cyst assemblages (Sample 103-641A-7X-3, 24-26 cm, has 36 morphotypes for one slide). The nine samples collected throughout the CTBE, from Samples 103-641A-6X, CC (35-37 cm), to 103-641A-6X-7, 26$29 \mathrm{~cm}$, contain very poorly diversified populations with few badly preserved individuals. For example, Sample 103-641A-6X, CC (21-24 cm), contains six morphotypes in two slides and Sample 103-641A-6X-7, 26-29 cm, has 14 morphotypes in four slides. The 16 samples from strata overlying the CTBE, from Samples 103-641A-6X-7, 15-18 cm, to 103-641A-3X-1, 119-120 cm, are barren. The list of samples is given in Appendix B.

Dinoflagellate occurrences are compared chiefly with those from onshore sections in the Cenomanian type area and other circum-Atlantic onshore outcrops. 
Biostratigraphic Results

\section{Unit $A$}

From Samples 103-641A-6X-7, 15-18 cm, to 103-641A-3X-1, $119-120 \mathrm{~cm}$, the palynological residues are barren. No data are available.

\section{Units $C$ through $E$}

Eight dinoflagellate cysts and 2 acritarcha were found in the nine CTBE samples. Trithyrodinium suspectum has its basal occurrence in Sample 103-641A-6X, CC (35-37 cm). T. suspectum is present in the Cenomanian of Canada (Manum and Cookson, 1964; Davey, 1970). In the western North Atlantic, the appearance of T. suspectum defines the middle to upper Cenomanian T. suspectum Zone (Habib, 1977; Habib and Knapp, 1982). The appearance of $T$. suspectum is used to characterize the upper Cenomanian in worldwide zonations and the upper lower Cenomanian in the Tethyan realm (Williams and Bujak, 1985). Thus, the middle to late Cenomanian age proposed for Sample 103-641A-6X, CC (35-37 cm), makes it the oldest sample collected from the CTBE.

Many species of stratigraphic interest were observed from Samples 103-641A-6X, CC (27-30 cm), to 103-641A-6X-7, 26$29 \mathrm{~cm}$. Sample 103-641A-6X-7, 26-29 cm, is the last sample yielding dinocysts, with 13 species. T. suspectum and Palaeohystrichophora infusorioides are abundant. Thus, Samples 103641A-6X, CC (27-30 cm), to 103-641A-6X-7, 26-29 cm, suggest a middle to late Cenomanian age also.

\section{Sediments Below the CTBE}

Sample 103-641A-7X, CC (18-20 cm), yielded 15 species, two of which are of stratigraphic interest, Ascodinium verrucosum subsp. verrucosum and Maghrebinia perforata (= Pterodinium perforatum). $M$. perforata has a first stratigraphic occurrence within the middle Albian of France (Davey and Verdier, 1971; Foucher, 1980). A. verrucosum subsp. verrucosum is known in the upper Albian of northwest Europe (Davey and Verdier, 1973; Fauconnier, 1983) and in the Tethyan realm (Williams and Bujak, 1985). Both of these species reach into the Cenomanian. Late Albian is the oldest age assigned to Sample 103-641A-7X, CC (18-20 cm), which bears Kiokansium williamsii, Leptodinium? delicatum, and Kleithriasphaeridium loffrense. $K$. williamsii has been recorded from the Cenomanian of Canada (Singh, 1983). L.? delicatum is known from the middle Albian (Brideaux and McIntyre, 1975) and Cenomanian (Davey, 1969 ) of Canada. $K$. loffrense is known to appear in the Cenomanian of the Paris Basin (Foucher, 1979) or in the Cenomanian type area (Fauconnier, 1983). The range charts of $K$. williamsii and $L$. ? delicatum are not well known, and the $K$. loffrense specimen is badly preserved. Problems exist in determining the exact position of the Albian/Cenomanian boundary, and other species are necessary to characterize the Cenomanian. Thus, a latest Albian to early Cenomanian age is attributed to Sample 103-641A-7X, CC (18-20 cm).

Spiniferites scabrosus occurs in Sample 103-641A-7X-5, 21$23 \mathrm{~cm}$, and Achomosphaera sagena occurs in Sample 103-641A$7 \mathrm{X}-3,24-26 \mathrm{~cm}$. In the Paris Basin and northern Europe, $S$. scabrosus appears in the Cenomanian (Foucher, 1979), and $A$. sagena is known from the Cenomanian of England and from Sites 545 and 547 of DSDP Leg 79, offshore of northwest Africa (Mazagan Plateau; Below, 1982). The preceding discussion of stratigraphy suggests that Sample 103-641A-7X-3, 21-23 cm, is Cenomanian in age.

In Sample 103-641A-7X-1, 84-86 cm, the dinocyst population is rare and only one species appears. Kionansium sp. GAL suggests an early? Cenomanian age for the sample, making it the oldest sample below the CTBE.
The distribution of the 58 dinoflagellate cysts and the two acritarch taxa found in these samples is tabulated in Table 3. Taxonomic notes are given in Appendix C, and a taxa list is given in Appendix D. Biostratigraphically important forms are shown in Plate 7.

In summary, biostratigraphic assignments of Hole 641A samples are as follows (see Table 3 ):

$3 \mathrm{X}-7,119-120 \mathrm{~cm}$, to $6 \mathrm{X}-7,15-18 \mathrm{~cm}$ : lithologic Units A and $\mathrm{B}$-barren

$6 \mathrm{X}-7,26-29 \mathrm{~cm}$, to $6 \mathrm{X}, \mathrm{CC}(35-37 \mathrm{~cm})$ : lithologic Units B, $\mathrm{C}, \mathrm{D}$, and $\mathrm{E}-$ middle to upper Cenomanian

7X-1, 84-86 cm, to 7R-3, 24-26 cm: lithologic Unit E-lower Cenomanian

$7 \mathrm{X}-4,88-90 \mathrm{~cm}$, to $7 \mathrm{R}, \mathrm{CC}(18-20 \mathrm{~cm})$ : lithologic Unit Eupper Albian/lower Cenomanian

\section{Spores and Pollen Grains}

Thirty-eight samples from Hole 641A were studied for spores and pollen grains, for which we present their stratigraphic distribution and propose a zonation. The pollen zones at Site 641 are compared with those encompassing the CTBE at Site 398 and with those proposed by Habib $(1977,1978,1979)$ for Sites 101, 105, 387, and 391 and by Hochuli and Kelts (1980) for Sites 417 and 418 , in the western North Atlantic. An age assignment is suggested by comparison with previous palynological studies of outcropping formations dated by ammonites in the Cenomanian type region near Le Mans (France) by Laing (1975), Durand and Louail (1976), and Juignet et al. (1983) and in the Turonian type region around Tours (France) by Robaszinski et al. (1982). The palynological investigations of Hasenboehler (1981) and Moron $(1981,1983)$ in the Occidental Portuguese Basin were also helpful for our purpose. In consideration of the paleogeographic scheme of the Iberian and North American margins, we also compare the palynological zonation at Site 641 with that proposed for the Cretaceous system of the Middle Atlantic Coastal Plain by Doyle and Robbins (1977) and Christopher (1979).

\section{Biostratigraphic Results}

The range chart (Table 4) is the basis for the recognition of three palynological zones at Site 641 . Zone I is characterized by the presence of Caytonipollenites pallidus, Alisporites elongatus, and Applanopsis trilobatus, extending into the upper part of the cored section from Hole $641 \mathrm{C}$. Zone II is characterized by the first appearance of Rugubivesiculites rugosus and the disappearance of $C$. pallidus, A. elongatus, and A. trilobatus. Zone III is differentiated by the first occurrence of Normapolles, with the genera Atlantopollis and Complexiopollis.

The same criteria used to differentiate these three zones were recognized at Site 398 (Table 5) by Taugourdeau-Lantz et al. (1982). But the scarcity of Monocolpates, Tricolpates, and Tricolporates, as commonly noted in the eastern North Atlantic, prevents us from recognizing the zonation of Habib (1977). A comparison of palynological zonation is proposed in Figure 13. Age assignments are tabulated in Table 4, biostratigraphically important species are shown in Plate 8 , and the taxa list is presented in Appendix E.

\section{Age Assignment of the Three Palynological Zones}

\section{Zone I}

C. pallidus, pollen of Caytoniales, is a species occurring from the Triassic on. At Site 398, C. pallidus was recovered up to Section 398D-76-1, at the base of the upper Albian. Kotova (1978) recovered $C$. pallidus at Site 370 up to Core 370-27 in the Cenomanian. C. pallidus was recovered by Kemp (1970) up to the upper Albian in southern England. Fauconnier (Juignet et al., 
Table 3. Distribution of dinoflagellate cysts in Hole 641A.

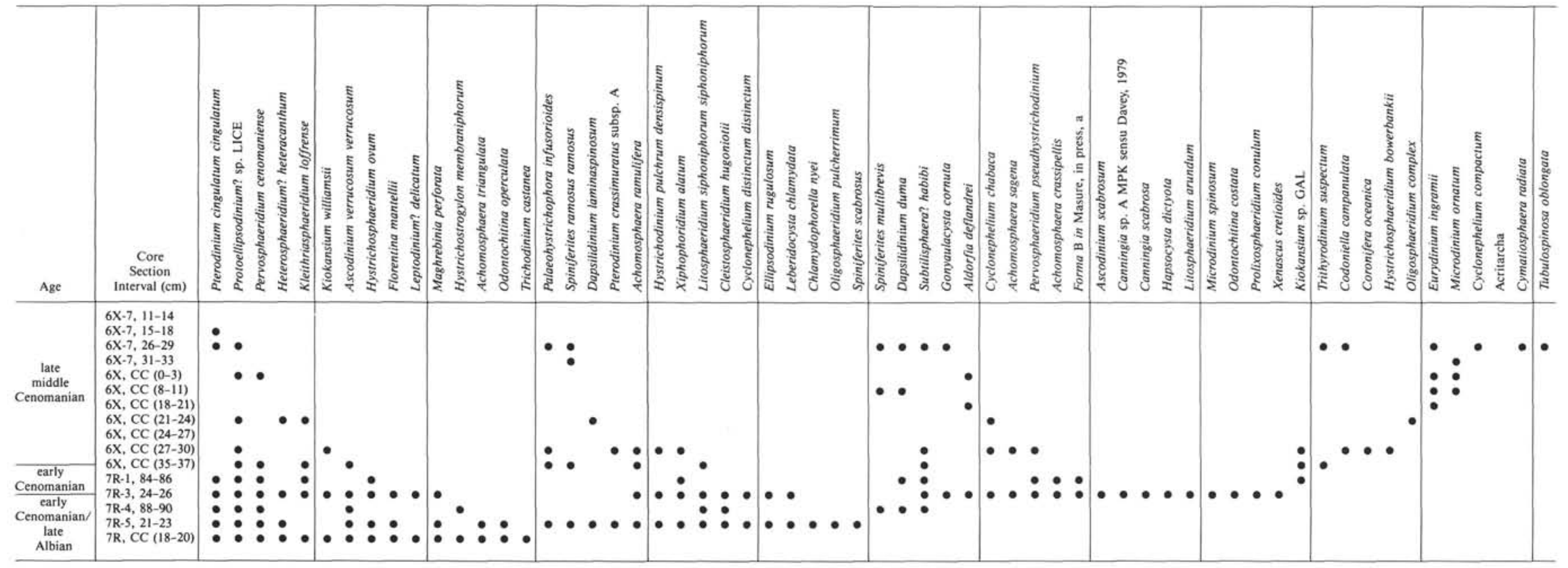


Table 4. Stratigraphic distribution of spores and pollen grains in the transition interval between the Hatteras Formation and the Plantagenet Formation at Site 398.

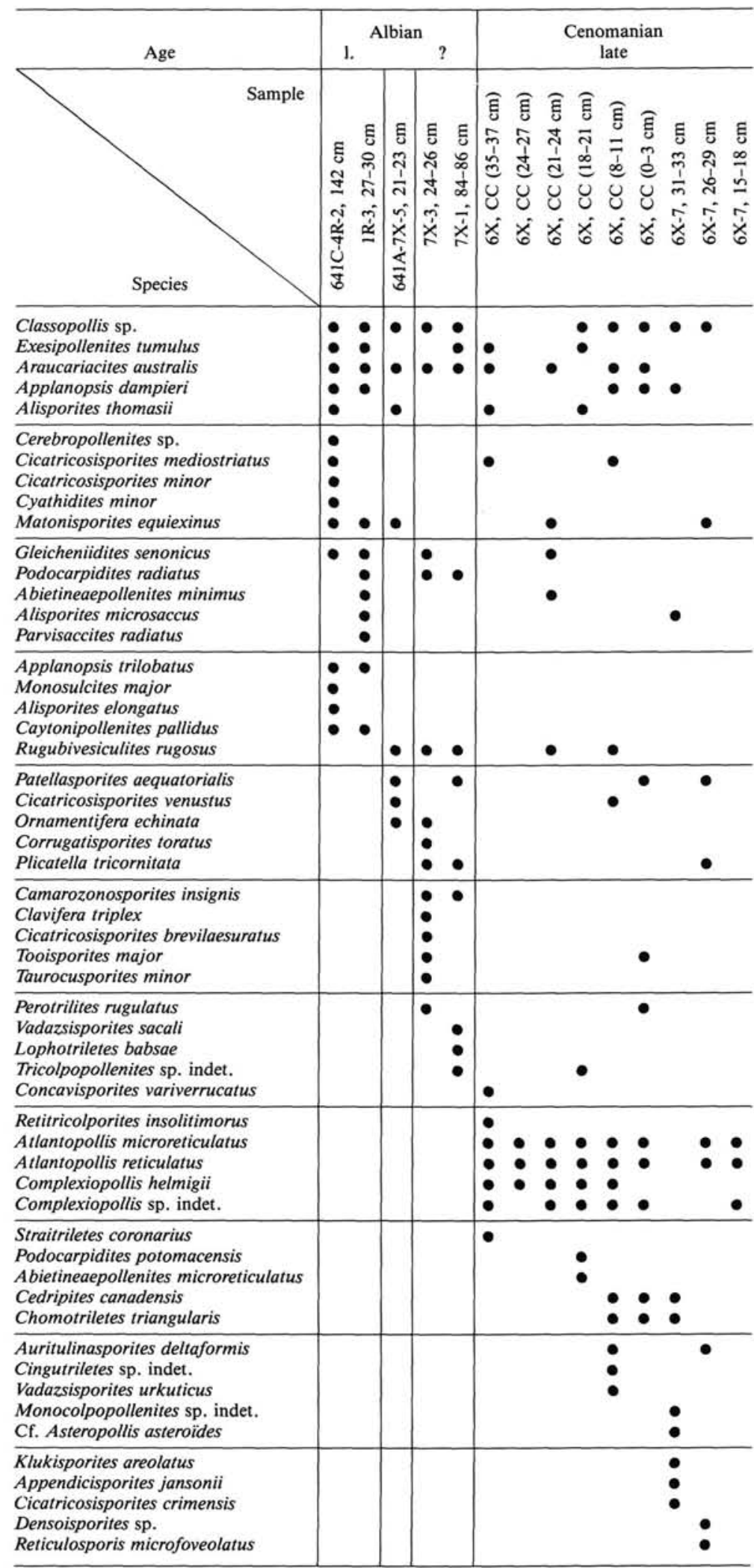


Table 5. Stratigraphic distribution of spores and pollen grains in the transition interval between the Hatteras Formation and the Plantagenet Formation at Site 398.

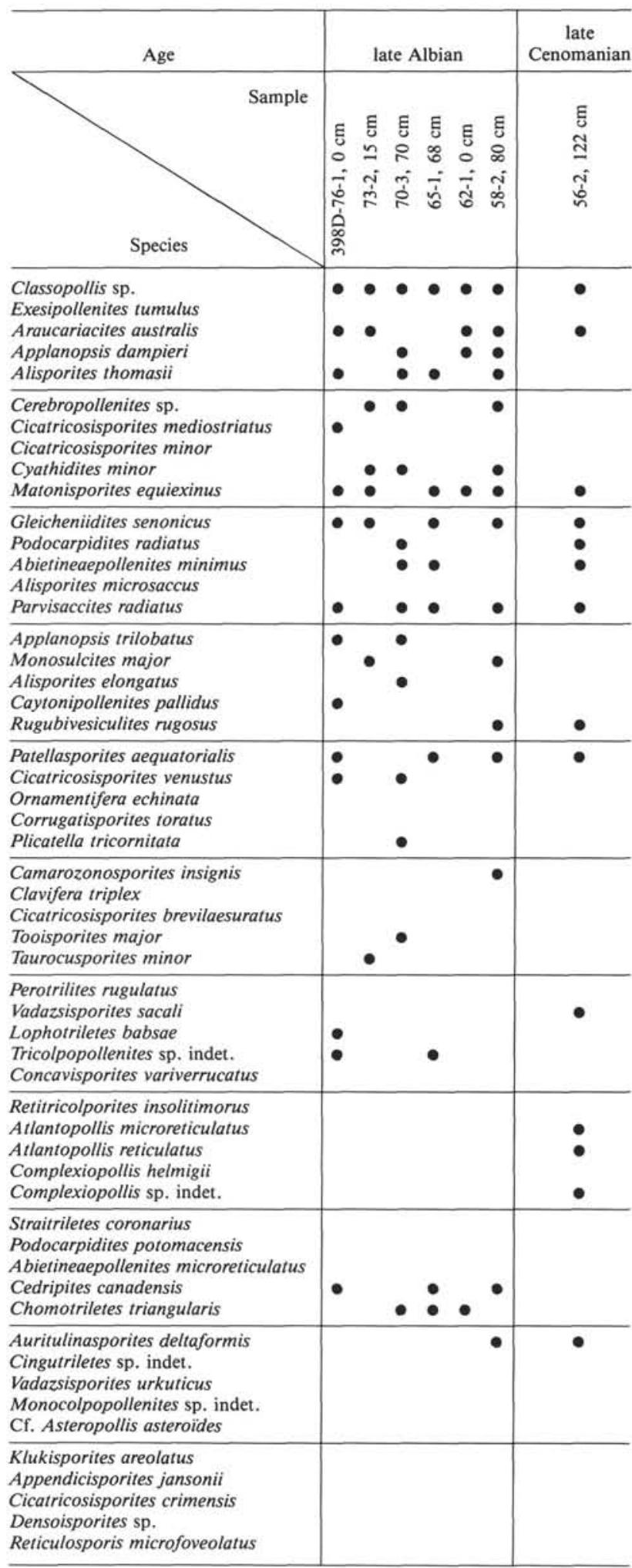

1983) recovered this species in the upper Albian of the Ballon well (France) but not in the uppermost Albian. Hasenboehler (1981) recovered it in the Occidental Portuguese Basin up to the upper Albian. In his comprehensive study of the microflora of the Potomac Group of Maryland, Brenner (1963) listed this species without limitation as to a precise zone.

$A$. elongatus is a rare species that was recovered up to Section 398D-70-3 in the upper Albian at Site 398. It was recovered by Kemp (1970) from the base of the Aptian to the base of the upper Albian. Batten (1979) cited this species at Site 400, from Samples $400 \mathrm{~A}-62-2,41-43 \mathrm{~cm}$, to $400 \mathrm{~A}-63-2,80-83 \mathrm{~cm}$, in the upper Albian. A. elongatus is also present in the Cenomanian of Alberta, Canada (Singh, 1983).

A. trilobatus, pollen of Araucariaces, occurs from the Toarcian on. At Site $398, A$. trilobatus was recovered up to Core 398D-70-3, in the upper Albian. It was recovered from the Barremian to the base of the upper Albian by Kemp (1970). Batten (1979) recovered it at Site 400 in Sample 400A-64-3, 52-55 cm, at the base of the upper Albian. Hasenboehler (1981) recovered A. trilobatus up to the top of the upper Albian, but not in the uppermost Albian in the Occidental Portuguese Basin.

We conclude a late Albian age for zone I, which corresponds to the uppermost part of the sequence at Hole 641C.

\section{Zone II}

$R$. rugosus was described by Pierce (1961) in the lower Upper Cretaceous (Cenomanian) of Minnesota. At Site 398, $R$. rugosus was recovered from Samples 398D-56-2, $122 \mathrm{~cm}$, to 398D$58-2,80 \mathrm{~cm}$. Its first appearance is in the uppermost Albian (Müller et al., 1983, 1984). In European assemblages, this species is rarely recognized. Azéma et al. (1972) recovered Rugubivesiculites $\mathrm{sp}$. in the middle Cenomanian of Vendée (western France). Moron (1981) recovered it in Portugese Senonian strata, but Hasenboehler (1981) did not mention it. Deàk and Combaz (1967) figured many Disaccites in the Wealden (lowermost Cretaceous) and Cenomanian strata from Charentes (western France) but did not include $R$. rugosus. This species is commonly listed in North American assemblages (e.g., Pierce, 1961; Brenner, 1963, 1967; Norris, 1967; Paden Phillips and Felix, 1971). Doyle and Robbins (1977) also noted the absence of $R$. rugosus in Europe and assigned a latest Albian age to their subzone IIC, which is characterized by the first occurrence of this species with some Tricolporoidates pollen grains in the Atlantic Coastal Plain of North America.

We conclude a late Albian age for the base of zone II, beginning with Sample 103-641A-7X-5, 21-23 cm.

\section{Zone III}

The first appearance of Normapolles with the genera Atlantopollis and Complexiopollis was noted at Site 398 in Sample $398 \mathrm{D}-56-2,122 \mathrm{~cm}$, with an abundance of $15 \%$ of the sporopollinic sum. Taugourdeau-Lantz et al. (1982) dated this sample as late Cenomanian by comparison with the assemblages of the Occidental Portuguese Basin. In his palynostratigraphic zonation of the western North Atlantic, Habib (1977) assigned a late middle Cenomanian age to the first appearance of Complexiopollis. This pollen group belongs to the Angiosperms.

In the European Cenomanian outcrops dated by ammonites, Normapolles were recovered in the upper part of the middle Cenomanian. Laing (1975) recovered Complexiopollis cf. subtilis (Krutzsch) in the Jukes-Brownei horizon (uppermost horizon of the Rhotomagense ammonite zone), together with Triporopollenites curtisi Laing and Triporopollenites worbarrowensis Laing (Durand and Louail, 1976). Durand in Louail et al. (1978) noted the first appearance, with a low percentage, of Normapolles with Complexiopollis vulgaris and Atlantopollis microreticulatus in the upper half of the middle Cenomanian (see also Médus et al. (1980) for a discussion of the first appearance of the group Normapolles). Sole de Porta (1978) reported Atlantopollis and Complexiopollis in northwest Spain, in a section belonging to the Rotalipora greenhornensis foraminiferal zone. This zone is dated 
West

Age

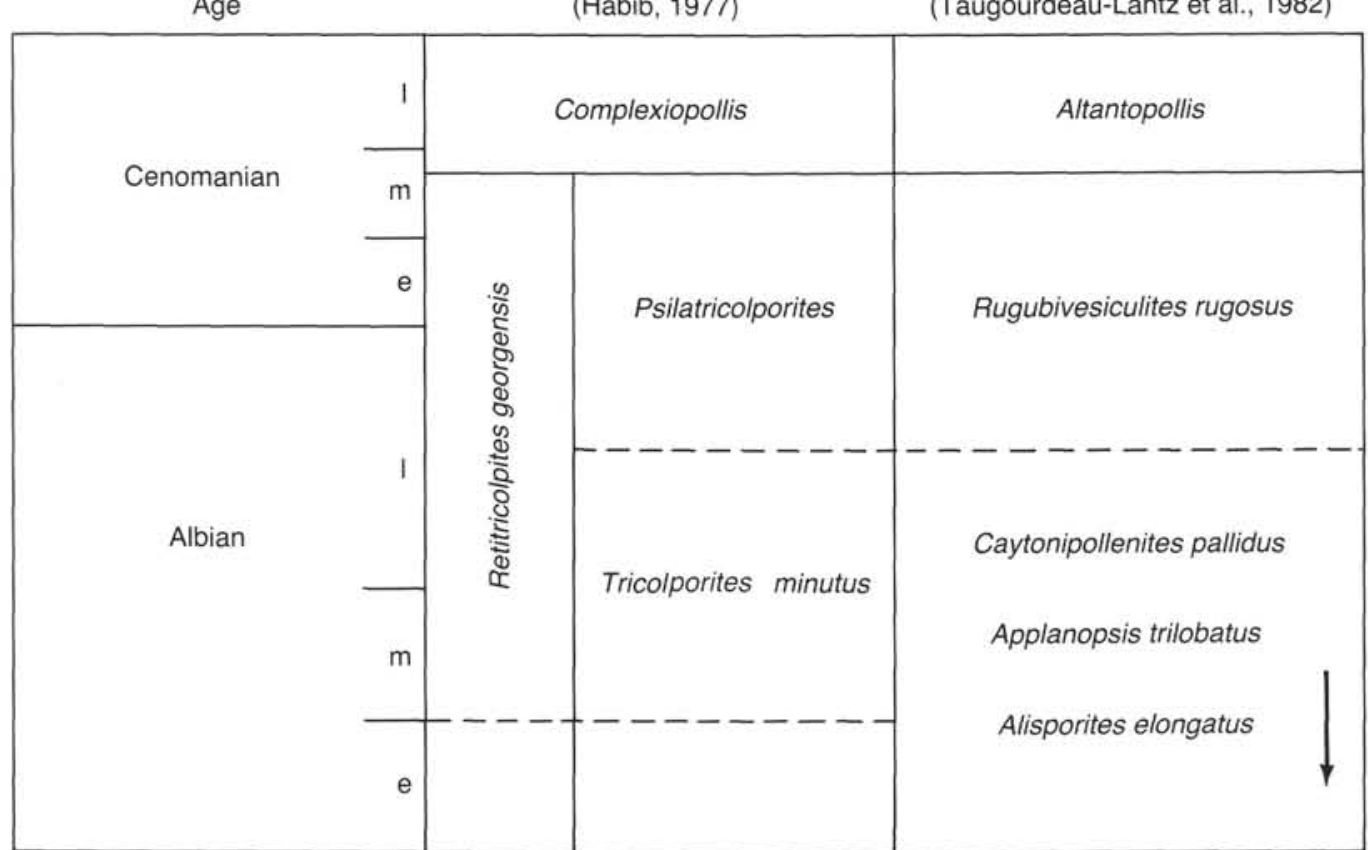

Figure 13. Comparison of the Albian/Cenomanian palynological zonations on each side of the Atlantic Ocean. middle and late Cenomanian (Robaszynski and Caron, 1979), not limited to late Cenomanian, as was thought previously.

Hasenboehler (1981) recovered the first Atlantopollis and Complexiopollis in uppermost middle Cenomanian, just below the Neolobites vibrayeanus Zone in the southern part of the Occidental Portuguese Basin, but in the northern part of the basin, Moron (1981) observed a lack of Normapolles in middle Cenomanian strata and their appearance in the upper Cenomanian. According to Kedves and Párdutz (1983), the genus Atlantopollis has its first appearance in the upper Cenomanian. For the opposite side of the Atlantic, Christopher (1979) presented an extensive bibliographical analysis of Cretaceous angiosperm pollen studies. Referring to his own analysis, he proposed four assemblage zones in the Upper Cretaceous. The first one is the Complexiopollis-Atlantopollis Zone, which occurs throughout the Woodbridge Clay and Sayreville Sand members of the Rari$\tan$ Formation. Only two of the Normapolles genera present in this zone are considered by Christopher (1979) to be of at least middle and possibly late Cenomanian age. In the overlying zone II, many genera of Normapolles have their first appearance.

With the occurrence of the genera Atlantopollis and Complexiopollis, we are able to correlate the interval consisting of Samples 103-641A-6X-7, 15-18 cm, to 103-641A-6X, CC (35-37 $\mathrm{cm})$, with the first zone of Christopher (1979).

\section{Relative Abundance (Fig. 14 and Table 6)}

At Hole 641A, the abundance of the genus Atlantopollis is conspicuous, reaching as much as $60 \%$ of the whole flora at its first appearance. At Site 398, in Sample 398D-56-2, $122 \mathrm{~cm}$, this pollen comprises up to $15 \%$ of the total palynomorphs (Taugourdeau-Lantz et al., 1982). Hasenboehler (1981) observed a $4 \%$ contribution of Normapolles in the uppermost middle Cenomanian and $15 \%$ contribution in the upper Cenomanian. Moron $(1981,1983)$ recovered a component of $20 \%$ Normapolles in the upper Cenomanian. Christopher (1979) noted that Normapolles appears to decrease in abundance downward throughout
Table 6. Percentages of pollen grains and spores, Hole 641A.

\begin{tabular}{lccccc}
\hline \multicolumn{1}{c}{ Sample } & Normapolles & Disaccites & Classopollis & Spores & Others \\
\hline $6 X-7,31-33 \mathrm{~cm}$ & 69.5 & 25.3 & 2.4 & 1.6 & 1.2 \\
$6 \mathrm{X}, \mathrm{CC}(0-3 \mathrm{~cm})$ & 55.4 & 37.3 & 2.9 & 3.2 & 1.2 \\
$(8-11 \mathrm{~cm})$ & 65.8 & 22.5 & 6 & 3.4 & 2.3 \\
$(35-37 \mathrm{~cm})$ & 60.9 & 35.6 & 2.0 & 0.5 & 1.0 \\
$7 \mathrm{X}-1,84-86 \mathrm{~cm}$ & & 43.5 & 15.5 & 40.0 & 1.0 \\
$7 \mathrm{X}-3,24-26 \mathrm{~cm}$ & & 39.3 & 26.0 & 31.3 & 3.4 \\
\hline
\end{tabular}

the Complexiopollis-Atlantopollis assemblage Zone (see also fig. 6 in Christopher, 1979).

At Site 641 , we observed a decrease in the relative abundance of Gymnosperm pollen, especially Classopollis, that correlates with the first occurrence of Normapolles (Fig. 14 and Table 6). This observation is similar to that of Moron $(1981$, p. 189), who wrote "le début du Cénomanian supérieur voit se produire des évènements importants... dans les échantillons de la base du niveau à Neolobites vibrayeanus, les Classopollis commencent à diminuer pour n'être plus que très peu représentés dans les niveaux supérieurs. Dans le même temps ou peut-être un peu plus tôt, apparaissent les Normapolles. Ces pollens d'affinité angiospermique, occupent rapidement une place importante dans la microflore."

In consideration of the presence of only two genera of Normapolles, Atlantopollis and Complexiopollis, and their great abundance, we conclude a late Cenomanian age for the section including Samples 103-641A-6X, CC $(35-37 \mathrm{~cm})$, to 103-641A$6 \mathrm{X}-7,15-18 \mathrm{~cm}$.

\section{Remarks}

A single questionable specimen, perhaps a Normapolles, figured on Plate 8 (Figs. 16 and 17), was observed in Sample 103$641 \mathrm{~A}-7 \mathrm{X}-3,24-26 \mathrm{~cm}$. If it is a true Normapolles, this sample would be late middle Cenomanian in age. 


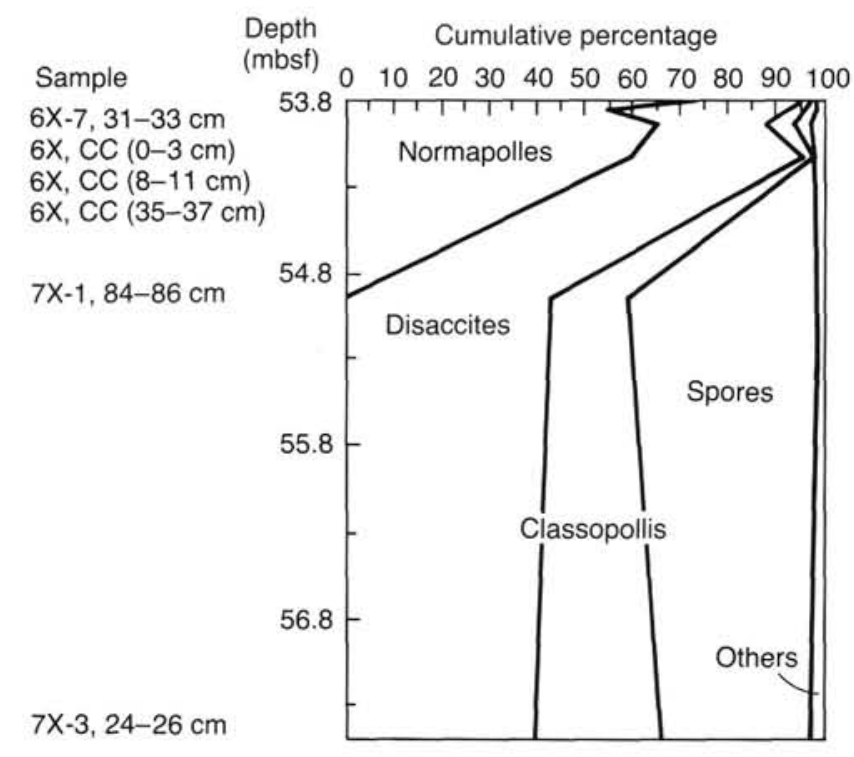

Figure 14. Relative frequencies of spores and pollen groups in Hole $641 \mathrm{~A}$. Spores and gymnosperm pollen have a strong reduction at the appearance of the Normapolles.

We did not observe the evolution of the Atlantopollis exine ornamentation noted by Moron (1983) as more reduced in the upper Cenomanian and more robust in the Turonian.

The particularly high relative abundance of Normapolles at Hole $641 \mathrm{~A}$ can be explained possibly by a preference for quiet sedimentation areas, away from marine currents.

In summary, we observed the same succession of index spores at Sites 641 and 398 on the Iberian margin. The thorough biostratigraphic study of Site 398 and the palynological studies of outcropping formations enabled our delimitation of three zones: upper Albian at the top of Hole 641C, uppermost Albian beginning with Sample 103-641A-7X-5, 21-23 cm, and upper Cenomanian beginning with Sample 103-641A-6X, CC (35-37 cm).

This zonation is in good accordance with the results reported by Drugg and Habib (this volume) from Hole 641A: "Most samples studied from this blackish, organic-carbon-rich clay interval of Core 103-641A-6X contain residues rich in well-preserved amorphous debris of the xenomorphic facies. These samples contain classopolid and bisaccate pollen grains and few pteridophyte spores. The Normapolles pollen genera Atlantopollis and Complexiopollis, each represented by several species, are common in these samples and indicate a Late Cretaceous age within the Cenomanian-Turonian. Samples 103-641A-6X-7, 24-25 cm, 103-641A-6X, CC (16-17 cm), 103-641A-6X, CC $(34-35 \mathrm{~cm})$, and 103-641A-6X, CC (38-39 cm), contain smaller organic residues but a more varied dinoflagellate flora, including Spiniferites cingulatus, Palaeohystrichophora infusorioides Deflandre, Codoniella psygma, and Odontochitina operculata (Wetzel) Deflandre and Cookson. Sample 103-641A-6X, CC (34-35 cm), also contains Chatangiella sp. and Protoellipsodinium sp. sensu Foucher (in Robaszynski et al., 1982, pl. 11, figs. 1 and 2). This sample also contains the Normapolles pollen species identified as Atlantopollis sp. 3 by Legoux (in Robaszynski et al., 1982). The genus Chatangiella does not occur in sediments older than early Turonian. In the type region of the Turonian studied by Robaszynski et al. (1982), Foucher's species Protoellipsodinium sp. is restricted to the Cenomanian, but adjacent to the Cenomanian/Turonian boundary. The pollen Atlantopollis sp. 3 is restricted to the Turonian in the type region. Based on this evidence and the diversification of Normapolles pollen types, Sample 103-641-6X, CC (34-35 cm), is considered to be of Turonian age and possibly close to the Cenomanian/Turonian boundary."

\section{Radiolarians}

Upper Cretaceous radiolarian-rich intervals in the North Atlantic are not very well documented. The preservation of these faunas is generally poor, and abundance, diversity, and biostratigraphic value reflect the diagenetic history of the host sediment rather than the primary productivity and diversity of these faunas. Sanfilippo and Riedel (1985), Foreman (1977), Wolfart (1982), and Empson-Morin (1984) give compilations of Upper Cretaceous radiolarian occurrences in the North Atlantic based on Deep Sea Drilling Project (DSDP) data. However, the biostratigraphic control is generally poor from calcareous planktonics.

There are several exceptions from this general situation (Thurow, this volume), one of which is the CTBE interval. Radiolarians are abundant and locally well preserved in the lower Campanian, at the Cenomanian/Turonian boundary, and in the upper Albian, lower Albian, and Barremian. These blooms in radiolarian abundance and preservation coincide, at least partially, with the well-established succession of Cretaceous oceanic events in the North Atlantic.

CTBE radiolarian associations have not been documented from the North Atlantic, although strata deposited during this event are widely recorded (Müller et al., 1983, 1984; Herbin et al., 1986b; Schlanger et al., 1987). Onshore, the dominance of biosiliceous faunas during this event has been recorded in African coastal basins, as well as in the Alpine fold belts surrounding the western Mediterranean (Arthur and Premoli Silva, 1982; Thurow et al. 1982; Kuhnt et al., 1986; Thurow and Kuhnt, 1986).

\section{METHODS}

The radiolarian samples were prepared following standard micropaleontological techniques and the methods described by Thurow (this volume).

\section{Upper Cretaceous in Hole $641 \mathrm{~A}$}

The record at Site 641 is very poor. Two radiolarians were found in Unit A (Sample 103-641A-4X-1, 48-52 cm), Sethocapsa cf. Sethocapsa simplex and a nassellarian that is generally named Stichomitra communis by the authors (Thurow, this volume). $S$. simplex is recorded from the upper Albian to the top of the Turonian in Japan, and S. communis is common in the Turonian sediments of southern Europe and northwestern Africa. The stratigraphic ranges of both forms are not very well established; therefore, the precise age of the sample remains uncertain.

In Unit D (Sample 103-641A-6X, CC [21-24 cm]), we found a zeolitized, and therefore doubtful, Pseudoaulophacid with a domed pillowlike shape. Such forms can be ascribed to the genera Alievium, and the shape suggests a latest Cenomanian or younger species. This assumption is supported by the skeletal structure, in which remains of the typical wheel-like skeletal elements are still identifiable.

Rich radiolarian faunas at Site 641 do not occur above Sample $103-641 \mathrm{C}-1 \mathrm{R}-3,84-87 \mathrm{~cm}$, which is roughly middle Albian. Samples from the lower part of Unit A to the top of Unit E are characterized by high amounts of zeolite, which are most likely the remains of what were otherwise rich radiolarian faunas of the CTBE.

\section{CTBE Interval at Hole 398D}

The radiolarians common to the CTBE interval at Site 398 are different from those found at Site 641 and are even locally highly enriched (Pl. 4, Fig. 2). Zeolitization or recrystallization 
into quartz was observed to some extent, but layers remain in the CTBE interval that contain sufficiently preserved radiolarians to allow biostratigraphic correlation with known CTBE assemblages onshore.

Sampling of Hole 398D, including the CTBE interval, was based on the compilation of Sigal (1979), which provides an overview of the abundance, preservation, and skeletal mineralogy of Lower to middle Cretaceous faunas found at Site 398, and Schaaf's (1985) list of radiolarian-rich intervals. The Upper Cretaceous brownish claystones (cf. Unit A at Hole 641A) at this site were not considered; according to Shipboard Scientific Party, 1979), they are devoid of radiolarians.

Fifteen samples of the interval from Samples 398D-56-1, 112$116 \mathrm{~cm}$, and 398D-56-3, 145-149 cm, were studied, and detailed results are presented by Thurow (this volume). This was the first time that it was possible to obtain and describe radiolarian assemblages straddling the Cenomanian/Turonian boundary, including the entire CTBE interval, in the North Atlantic sequences. We are now able to compare CTBE radiolarian assemblages directly to well-known onshore CTBE assemblages.

Radiolarians are common but generally poorly preserved in the CTBE interval at Hole 398D. The preservation does not allow for a statistical evaluation of the fauna, but enough specimens were sufficiently preserved to establish a precise biostratigraphy reflecting the paleoceanographic importance of these radiolarian-rich intervals. Rich radiolarian faunas are found up to Sample 398D-56-2, 2-6 cm, into the red zeolitic claystones just above the CTBE interval (which corresponds approximately to Unit B and/or the base of Unit A at Hole 641A). This distribution is similar to that at several onshore sections, where the black shale facies also disappears first, whereas the rich radiolarian faunas persist up to the middle Turonian. In the true brown claystones of the Plantagenet Formation (Pl. 4, Fig. 1, left column), radiolarians are missing. The radiolarian record below the CTBE is diffuse; below Section 398D-56-3 (middle Cenomanian) radiolarians are scarce, not recurring, but in remarkable amounts, until Core 398D-62 (upper Albian).

The faunal composition in all samples studied is quite similar, with differences reflecting differential preservation rather than primary faunal distinctions. Biostratigraphically important species include Alievium superbum, Crucella cachensis, Pseudoaulophacus putahensis, Cavaspongia sp., Archaeodictyomitra simplex, Archaeodictyomitra squinaboli, Dictyomitra formosa, Novixitus weyli, Pseudodictyomitra carpatica, Pseudodictyomitra nakasekoi, Thanarla elegantissima, Thanarla veneta, and Theoconus coronatus. This association is the characteristic fauna around the CTBE.

The most important marker species at this time-C. cachensis (Pl. 4, Fig. 3)-has its first occurrence in Sample 398D-56-2, $98-102 \mathrm{~cm}$. This form is used as the marker for the onset of the CTBE (Thurow et al., 1982), and its FAD coincides with the extinction of the foraminifer genus Rotalipora in the uppermost Cenomanian, followed by the $W$. archaeocretacea foraminiferal zone (Thurow et al., 1982; Thurow and Kuhnt, 1986). The base of the $W$. archaeocretacea Zone is locally used to mark the Cenomanian/Turonian boundary (which would shift the CTBE to an "Upper Cenomanian Event"; see age assignments of the palynomorphs). Other biostratigraphers place the micropaleontologically less precise Cenomanian/Turonian boundary somewhere in the $W$. archaeocretacea Zone. There are several important species that are not influenced by this event, including Dumitricaia maxwellensis, Halesium quadratum, Halesium sexangulum, Pyramispongia glascockensis, and Pseudodictyomitra pseudomacrocephala. P. carpatica, T. elegantissima, and T. coronatus also became extinct at this event, which is marked by the FAD of $A$. superbum s.s., C. cachensis, Conocaryomma universa, A. squinaboli, and D. formosa.
A. superbum s.s. has its FAD together with $C$. cachensis in other CTBE occurrences and is present in Sample 398D-56-3, $57-61 \mathrm{~cm}$ (see discussion in Thurow, this volume). P. putahensis s.s. is similarly found together with the first occurrence of $C$. cachensis in other CTBE outcrops. In Samples 398D-56-3, 43$47 \mathrm{~cm}$, and 398D-56-3, 57-61 cm, both forms occur together with the planktonic foraminifer $R$. cushmani, which suggests a late Cenomanian age, several centimeters below the first occurrence of $C$. cachensis. Because the planktonic foraminifers are derived from detrital layers within the claystones, their biostratigraphic value is impaired. However, the sample is not older than late Cenomanian.

Comparison of the CTBE radiolarian inventory found at Site 398 with well-documented CTBE assemblages onshore for the Tethyan and Atlantic realms (Thurow et al., 1982; Kuhnt et al., 1986; Thurow and Kuhnt, 1986; Thurow, 1987), shows that the diversity at Site 398 is obviously less than that onshore. However, this might not be a primary reflection, because the missing species have fragile skeletons (e.g., the Neosciadiacapsidae). Thus, the low diversity can be explained by secondary destruction of the fragile skeletons during diagenesis.

\section{Nannofossils}

Nannofossils are scarce around the CTBE, and only samples from Units D and E contain nannofossil floras. Although this distribution is not useful in determining an absolute age for the black band, the nannofossils help to define the base of the event (Table 2 and Fig. 12). The condensed layer (Unit D) is the level where carbonate disappears, as do the nannofossils. The black band (Unit C), the overlying reduced-clay interval (Unit B), and the brown clay (Unit A) are barren of nannofossils (Applegate and Bergen, this volume). The first nannofossil sample, containing a poor and strongly dissolved flora (Pl. 6, Fig. 3), is in Sample 103-641A-6X, CC (21-24 cm), from the condensed interval (Unit D); Applegate and Bergen (this volume) assigned it an early to middle Cenomanian age. This age assignment can be extended down to Sample 103-641A-6X, CC $(40 \mathrm{~cm}), 13 \mathrm{~cm}$ below the top of Unit E.

Ages obtained from the nannofossils show that the onset of the CTBE is not older than middle Cenomanian. However, the absence of carbonate (and nannofossils) in the uppermost centimeters of Unit D might indicate a long time span with a strongly reduced sedimentation rate between the disappearance of the nannofossils and the deposition of the first black shale layer. This age assignment is in good accordance with the idea of a CTBE and matches the results obtained from the study of palynomorphs.

No nannofossil data are available from the Site 398 CTBE interval.

\section{Foraminifers}

Foraminifers are rarely found in deep-water sections of the CTBE interval. The CTBE environment was not favorable for either growth or preservation, but the foraminifers provide valuable data for the timing of strata immediately overlying and underlying this interval. The results obtained from Site 641 are tabulated in Table 2 .

The samples were prepared using standard micropaleontological techniques, including boiling with Calgon and treatment with $\mathrm{H}_{2} \mathrm{O}_{2}$.

\section{Calcareous Foraminifers}

No calcareous foraminifers, either planktonic or benthic, were found in the CTBE interval or the overlying red clays (Units AD), although rich faunas are found in the uppermost part of the Hatteras Formation (Unit E). Sample 103-641A-6X, CC (29 cm), and deeper samples include Hedbergella delrioensis, Hedberg- 
ella planispira, Globigerinelloides caseyi, and Schackoina cenomana. This assemblage is not highly characteristic, but it indicates a latest Albian to Cenomanian age. Deeper assemblages, such as found in Sample 103-641A-7X-3, 19-21 cm, contain Rotalipora brotzeni-greenhornensis together with Rotalipora appenninica, Rotalipora cf. Rotalipora reicheli, Praeglobotruncana delrioensis, and Praeglobotruncana stephani, which points to an early Cenomanian age, in accordance with the other microfossil data.

\section{Agglutinated Foraminifers}

One of the first micropaleontological signs of the CTBE observed by various workers is the lack of benthic life in the CTBE interval, mainly as a result of the anoxic environment at the sediment/water interface. Even at shallow sites, depauperation is fairly prominent. Agglutinated foraminifers are concentrated in the brownish greenish clays above the CTBE. The lower limit of the Upper Cretaceous microfossiliferous (for agglutinated foraminifers) interval coincides with Sample 103-641A-6X-7, 26-29 $\mathrm{cm}$, straddling the lithologic boundary between the greenish clay of Unit B and the underlying black shale of Unit C. This position confirms that Unit B is the strongly reduced lowermost part of Unit A.

Moullade et al. (this volume) described the faunas in detail and discussed their stratigraphic value. All faunas belong to the Recurvoides association, as defined by Haig (1979), and are regularly present. A generally important part of the assemblages consists of tubelike specimens belonging to stratigraphically insignificant taxa or to long-ranging forms (Bathysiphon/Rhabdammina/Rhizanmina/Dendrophrya complex). In the lower part of Unit A and in Unit B, species of biostratigraphic importance are Haplophragmium lueckei (Pl. 4, Fig. 4) and Uvigerinammina jankoi. They belong to the $H$. lueckei Zone, with the FAD of the nominate species at the base of the zone (Fig. 15). The first $H$. lueckei was found in Sample 103-641A-6X-7, 24-26 cm, which assigns a Turonian age to the sample (Figs. 12 and 15) and also to Unit $\mathrm{B}$, just above the black shale layer of Unit $\mathrm{C}$.

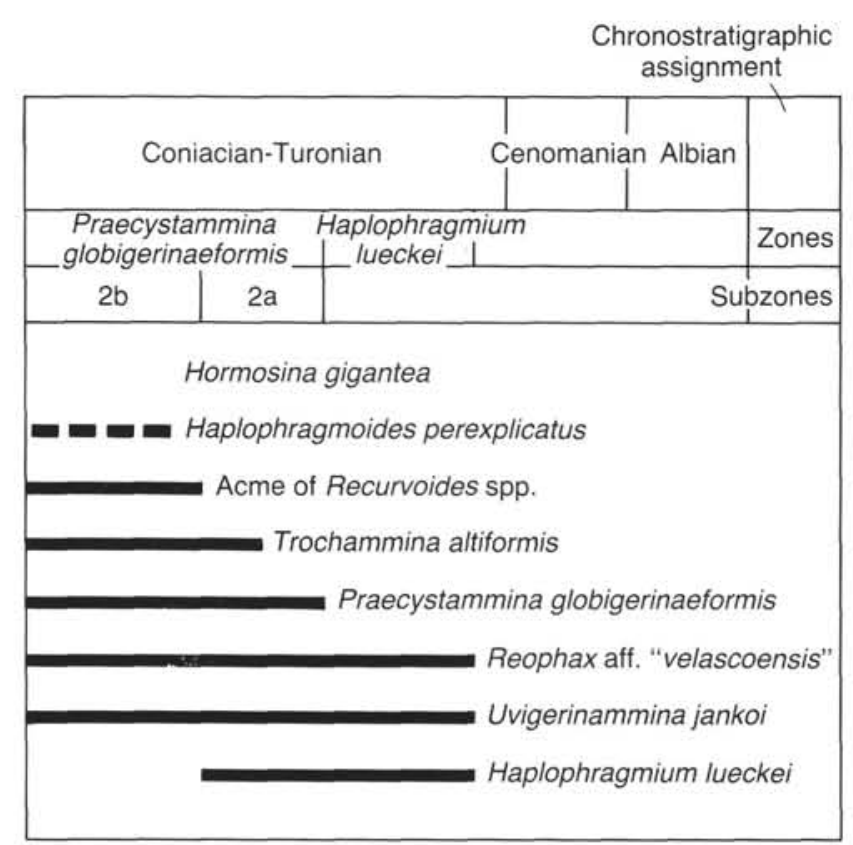

Figure 15. Middle Cretaceous zonation and range chart of biostratigraphically important agglutinated foraminifers (modified from Moullade et al., this volume).

\section{Site 398}

Sigal (1979) compiled the results of foraminiferal studies from the Lower to middle Cretaceous sequence drilled at Hole 398D. For the interval considered comprising the CTBE, he reported only a few occurrences, which were unfortunately obscured by redeposition. Our study confirms that foraminifers are concentrated predominantly in calcareous turbidites; thus, they are not considered in this paper.

\section{Ichthyoliths}

At the time of writing, the results of ichthyolith stratigraphy were not available for Holes 641A and 398D.

\section{MAGNETOSTRATIGRAPHY}

The magnetostratigraphic resolution in Hole 641A is poor in the upper part (Ogg, this volume) because of insufficiently dense sampling of a relatively condensed series, the slumping of Cretaceous strata into Pleistocene strata, and/or low core recovery. However, assignment of the lower part of the sequence (the CTBE interval in Core 103-641A-7X and the lower part of Core 103-641A-6X) to the Cretaceous (Aptian to the base of the Campanian) long normal polarity interval is a reasonable assumption. The Cretaceous magnetostratigraphy at Hole 398D is poor, but the CTBE interval also belongs to the Cretaceous (Aptian to the base of the Campanian) long normal polarity interval, according to Morgan (1979).

\section{DISCUSSION AND CONCLUSIONS}

\section{Biostratigraphy}

We used various approaches to obtain a continuous stratigraphic record of the CTBE sequence at Site 641, including studies of palynomorphs, foraminifers, radiolarians, and nannofossils. Although none of the fossil groups was found throughout Units A-E, we were able to restrict the age of the black shale to the Cenomanian/Turonian boundary interval, thereby proving that it virtually represents the Cenomanian/Turonian OAE (Schlanger and Jenkyns, 1976) at this locality.

This is also confirmed by the biostratigraphic results from the CTBE at nearby Hole 398D, where a much better resolution was obtained (Sigal, 1979; Taugourdeau-Lantz et al., 1982; Masure, 1984; Thurow, this volume), and the Cenomanian/Turonian boundary was fixed by the stratigraphy of several fossil groups. The prominent positive $\delta^{13} \mathrm{C}$ excursion also supports this age assignment. The beginning of the shift is approximately coeval with the base of the $W$. archaeocretacea foraminifer zone (Fig. 9), a less precise indication of the Cenomanian/Turonian boundary. In the thick, shallow deposits of the Tarfaya section (Fig. 9), where the biostratigraphic resolution is much sharper, the beginning of the shift coincides with the last occurrence of $R$. cushmani, just before the FAD of $W$. archaeocretacea. The isotope shift traces the CTBE in all environments and provides an excellent biostratigraphic marker even in sections poor in microfossils.

\section{Paleoenvironment}

The deep-marine environment occurrences of the CTBE have several distinct features in common. The most important are as follows:

Sedimentation of black shale enriched in total organic carbon, with organic matter of marine origin. The shales lack bioturbation and microbenthos.

A positive $\delta^{13} \mathrm{C}$ excursion.

Enrichment of trace metals. 
A sharp rise in the radiolarian/planktonic foraminifer ratio, which led to limestone chertification and the formation of siliceous sediments such as radiolarites and siliceous black shales.

A condensed section or strongly reduced sedimentation rate.

Organic sedimentation is not confined to a particular paleogeographic setting.

Our results confirm that all these attributes can be ascribed to the CTBE intervals at Sites 641 and 398.

The depositional environment at Site 641 , at the western end of the Galicia margin, was in a water depth of approximately $3500 \mathrm{~m}$. The sedimentation rate calculates as very low $(2-3 \mathrm{~m} /$ m.y.). The biostratigraphic control around the CTBE is not sufficient to provide exact data on the accumulation rate of Units $\mathrm{C}$ and $\mathrm{D}$, but values $\ll 1 \mathrm{~m} / \mathrm{m}$.y. are likely, in consideration that no unconformities have been detected. Such low sedimentation rates are explained by the peak transgression during the CTBE, which restricted the detrital supply and starved most of the depositional environments in the area. In addition, the depositional environment of Hole 641A, located in an restricted depression on the landward flank of a tilted block and away from major marine currents, provides a favorable scenario for the depletion of $\mathrm{O}_{2}$.

Units A and B are interpreted as a pelagic clay that accumulated slowly in an oxygenated environment below the CCD. It is possible that the sequence contains significant hiatuses in accumulation, as known from other North Atlantic sites with Upper Cretaceous strata, but this suggestion is not confirmed by the microfossil content (Moullade et al., this volume). The unique black shale layer of Unit $C$ clearly accumulated in a special environment favorable to the preservation of organic material. Unit D marks the strong condensation effect commonly observed in the deep-water CTBE intervals (Event 2 of Müller et al., 1983, 1984), and Unit $\mathrm{E}$ is interpreted as a pelagic sediment that accumulated in moderate water depths (i.e., above the CCD). The CTBE sequence at Site 641 is similar to other sedimentary expressions of this event in the North Atlantic (compilation in Herbin et al., 1986b).

The depositional environment at Site 398, at the southern apron of Vigo Seamount (Fig. 1) on the southern end of the Galicia Bank, was well below the regional CCD during the CTBE, a position similar to, but not as deep as, Site 641 . During the early and middle Albian, the sedimentation rate was very high ( $>100 \mathrm{~m} / \mathrm{m} . \mathrm{y}$.) as a result of regional subsidence. During the late Albian and early Cenomanian, the sedimentation rate decreased to $15 \mathrm{~m} / \mathrm{m}$.y. as transgression began and became lower than $1 \mathrm{~m} / \mathrm{m}$.y. during the CTBE.

There is no obvious difference between the mineralogy of both CTBE intervals studied and the general evolutionary trends of Cretaceous clay mineral assemblages in the North Atlantic. Clay mineral assemblages, as well as zeolites and other silica minerals, in the middle Cretaceous do not point to any pronounced or increased volcanic activity as reflected in the marginal deposits around the North Atlantic. This indication is not refuted by the results of mineralogical analysis of the sedimentary sequences studied, which reflect the CTBE. Furthermore, our results do not point to any pronounced climatic change during the CTBE, as suggested by Kemper (1987).

The organic matter component reflects a drastic change in the depositional environment in the uppermost Cenomanian. High amounts of marine organic matter are preserved in the sediments, which contain more than $10 \%$ marine organic carbon. These extremely high values require unusual environmental conditions, resulting from either extremely high productivity (such as recorded in coastal upwelling areas; Tarfaya section; Fig. 9) or better preservation of organic matter owing to anoxic deep-water conditions (such as recorded in the modern Black Sea). Areas of high productivity are generally characterized by high sedimentation rates (Stein et al., 1986), as in the the case of the Tarfaya section (Fig. 9), which was deposited within an upwelling regime. However, for the CTBE interval at Site 641 we calculated extremely low sedimentation rates (about $\ll 1 \mathrm{~cm} /$ $1000 \mathrm{yr}$ ); thus, generally higher paleoproductivities were unlikely.

The results from geochemical analyses of trace metals provide some intriguing arguments toward understanding the paleoceanography during the CTBE at Site 641 . The CTBE black shales exhibit a chemistry different from modern upwelling sediments. Well-preserved organic matter together with a high trace metal content can only be explained in terms of a sufficiently long time period for extraction of the metals from the seawater in conjunction with anoxic conditions for preservation of the organic matter during this extended time interval. Redeposition or rapid burial of the organic matter, a commonly suggested possible mechanism for the formation of black shale sequences (Arthur et al., 1984; Degens et al., 1986), has been detected in deep-water CTBE sequences (Thurow and Kuhnt, 1986) and would also have allowed an enhanced preservation of organic matter. But this hypothesis is contradictory to the high trace metal content of CTBE deposits at Site 641 and other locations (Brumsack, 1980; Brumsack and Thurow, 1986) and to the long time required for the extraction of these metals from seawater.

Thus, the trace metals provide an indication similar to that of the organic carbon data of high preservation under low sediment-accumulation rates. Anoxic conditions like those in the present-day Black Sea must have persisted during the CTBE at Site 641. Preliminary uranium analyses data indicate that the uranium isotope composition is similar to that of the Mediterranean sapropels, which also supports the likelihood of anoxic conditions.

In conclusion, this model does not exclude the idea that upwelling existed in favorable areas (comparable to the northwest African coastal basins), but the mechanism cannot explain the CTBE occurrences in the deeper marine environment.

\section{Silica}

Radiolarians in the Atlantic Basin are known to be not as abundant or as well preserved as in the Pacific Basin. This suggests that the poor preservation of siliceous skeletons may be due to the relatively small amount of silica that was deposited in the Cretaceous Atlantic Basin. Examinations for radiolarians at Sites 398 and 641 and other North Atlantic sites (Thurow, this volume) confirm this general observation. Contrary to this observation, however, the CTBE is accompanied by a short-term highly biosiliceous sedimentation. Radiolarians are commonly well preserved. Two explanations for this biosiliceous event are considered: (1) the fossilization potential for radiolarians was highly favorable in the environment influenced by the CTBE and (2) high productivity of biosiliceous organisms was probably related to widespread upwelling or, more generally, to changes in the paleoceanography and habitat of planktonic organisms (Kuhnt et al., 1986).

Several factors influence the discussion of these hypotheses. First, the radiolarian/planktonic foraminifer ratio was controlled mainly by the common dissolution of calcareous plankton in the CTBE deposits. Co-occurrences are very rare (e.g., in some margin series in the western Tethys; Thurow et al., 1982; Thurow and Kuhnt, 1986). The faunal content in these strata does not point to a pronounced decrease in the absolute amount of calcareous forms but to a strong increase in the total amount of radiolarians, shifting the ratio toward the radiolarians. In the deeper marine environment, where the calcareous forms are dis- 
solved, the high radiolarian content might be explained by a continuous radiolarian rain into a depositional environment that was almost starved for any detrital supply, thereby allowing the formation of organic-carbon-rich radiolarian shales over time.

It was suggested by Bralower and Thierstein (1984) that organic-carbon-rich shales were a favorable environment for preservation of the siliceous plankton. This argument is not very satisfactory, because rich radiolarian faunas are not found in the CTBE black shales at shallower sites in the western Tethys but are preferentially concentrated in intercalated pelagic limestone of the "Scaglia" type. This relation is true only for the limestone interval influenced by the CTBE; in general, the Upper Cretaceous Scaglia-type sections are devoid of radiolarians, which demonstrates that such limestones are typically not favorable for the preservation of siliceous microfossils.

Rich radiolarian faunas are not common only in the black shale intervals. They persist into deposits poor in or free from organic carbon-but with strongly increased sedimentation ratesup into the $P$. helvetica foraminifer zone (middle Turonian). The preservation of these faunas is not explained by a special depositional environment in an otherwise unfavorable ocean setting but by enlarged paleoproductivity of siliceous plankton. The widespread blooming of radiolarians can be traced into marginal seas. Hence, the radiolarians now widely recorded from onshore outcrops of the CTBE and faunal assemblages are globally quite similar. Although it is not ultimately clear as to why the biosiliceous component is so well preserved, there is strong evidence that this is related to higher paleoproductivity of biosiliceous tests, rather than to short-term conditions of special preservation.

In summary, the marine strata deposited during the CTBE display lithologic, faunal, and geochemical characteristics indicative of a chiefly anoxic depositional environment at Site 641 and a periodically oxygen-deficient one at Site 398 . Such an anoxic period characterized by the recurrence of organic-matterrich sediments is found in throughout the Atlantic for the latest Cenomanian and early Turonian (compilation in Herbin et al., 1986a, 1986b), as well as in neighboring basins (Fig. 16). The black laminated anoxic shales especially appear to be restricted to an expanded $\mathrm{O}_{2}$ minimum zone (Schlanger and Jenkyns, 1976; Arthur and Schlanger, 1979; Arthur et al., 1987; Schlanger et al., 1987). If one accepts that an expanded $\mathrm{O}_{2}$ minimum layer was responsible for the enhanced depth distribution of the CTBE black shale layer, then one is confronted with the fact that this minimum layer reaches down at least $3500 \mathrm{~m}$ at Site 641 .

There is virtually no sign of redeposition of the organic material in the black shale layer of the CTBE interval at Site 641, as was detected in some significantly deep occurrences of the CTBE (Arthur et al., 1984; Thurow and Kuhnt, 1986) where the organic matter is preserved due to fast burial. Thus, it is necessary to expand the oxygen-minimum zone at Site 641 to a depth of at least $3500 \mathrm{~m}$. At the time of the CTBE, only small areas of the Atlantic Ocean had deeply subsided, so most of the Atlantic Ocean was strongly $\mathrm{O}_{2}$-depleted or anoxic.

The global CTBE has been variously related to transgression, global upwelling, bolide impacts, (volcanic) extrusions, or a combination of several of these phenomena. However, an ultimately satisfying explanation and model are still lacking.

\section{ACKNOWLEDGMENTS}

Jürgen Thurow, Michel Moullade, and Keith Dunham wish to thank the Ocean Drilling Program for the invitation to participate on Leg 103 aboard the JOIDES Resolution and to sample Site 641. The National Science Foundation provided the samples from DSDP Site 398 of Leg 47B. E. Masure would like to express her acknowledgment to J. Taugourdeau-Lantz and G. Boillot, who made facilities and financial support available. The authors thank S. O. Schlanger (Evanston), W. E.
Dean (Denver), W. Ricken (Tübingen), and W. Schwentke (Tübingen) for their comments and review.

This work was supported by the German D.F.G. Grant Wi 112-25.

\section{REFERENCES}

Agelopoulos, J., 1964. Hystrichostrogylon membraniphorum n. g., n. sp. aus dem Heiligenhafener Kieselton (Eozän). Neues Jahrb. Geol. Palaeontol. Mh., 1964:673-675.

Alberti, G., 1961. Zur Kenntnis mesozoischer und alttertiärer Dinoflagellaten und Hystrichosphaeriden von Nord-und Mitteldeutschland sowie einigen anderen europäischen Gebieten. Palaeontographica Abt. $A, 116: 1-58$.

Arthur, M. A., 1979a. Origin of Upper Cretaceous multicolored claystones of the western Atlantic. In Tucholke, B. E., Vogt, P. R., et al., Init. Repts. DSDP, 43: Washington (U.S. Govt. Printing Office), $417-420$.

1979b. North Atlantic Cretaceous black shales: the record at Site 398 and a brief comparison with other occurrences. In Sibuet, J.-C., Ryan, W.B.F., et al., Init. Repts. DSDP, 47, Pt. 2: Washington (U.S. Govt. Printing Office), 719-738.

Arthur, M. A., Dean, W. E., and Stow, D.A.V., 1984. Models for the deposition of Mesozoic-Cenozoic fine-grained organic-carbon rich sediment in the deep sea. In Stow, D.A.V., and Piper, D.J.W. (Eds.), Fine-Grained Sediments: Deep Water Sediments and Facies: Geol. Soc. Spec. Publ. London, 15:527-560.

Arthur, M. A., and Premoli Silva, I., 1982. Development of widespread organic carbon-rich strata in the Mediterranean Tethys. In Schlanger, S. O., and Cita, M. B. (Eds.), Nature and Origin of Cretaceous Carbon-Rich Facies: London (Academic Press), 7-54.

Arthur, M. A., and Schlanger, S. O., 1979. Cretaceous "Oceanic Anoxic Events" as causal factors in development of reef-reservoir giant oil fields. AAPG Bull., 63:870-885.

Arthur, M. A., Schlanger, S. O., and Jenkyns, H. C., 1987. The Cenomanian-Turonian Anoxic Event, II: paleooceanographic controls on organic matter production and preservation. In Brooks, J., and Fleet, A. (Eds.), Marine Petroleum Source Rocks: Geol. Soc. Spec. Publ. London, 26:401-420.

Azéma, C., Durand, S., and Medus, J., 1972. Des miospores du Cénomanien moyen. Paleobiol. Cont., 3:1-54

Balme, B. E., 1957. Spores and Pollen Grains from the Mesozoic of Western Australia: Aust. C.S.I.R.O.

Barron, E. J., Harrison, C.G.A., Sloan, J. L., and Hay, W. W., 1981. Paleogeography, 180 million years ago to the present. Eclogae Geol. Helv., 74:443-470.

Batten, D. J., 1979. Miospores and other acid-resistant microfossils from the Aptian/Albian of Holes 400A and 402A, DSDP-IPOD Leg 48, Bay of Biscay. In Montadert, L., Roberts, D. G., et al., Init. Repts. DSDP, 48: Washington (U.S. Govt. Printing Office), 579587.

Below, R., 1981. Dinoflagellaten-Zysten aus dem oberen Hauterive bis unterem Cenoman Süd-West-Marokkos. Palaeontographica Abt. B, 176:1-145.

1982. Scolochorate Zysten der Gonyaulacacea (Dinophyceae) aus der Unterkreide Marokkos. Palaeontographica Abt. B, 182:151 .

1984. Aptian to Cenomanian dinoflagellate cysts from Mazagan Plateau, northwest Africa (Sites 545 and 547, Deep Sea Drilling Project Leg 79). In Hinz, K., Winterer, E. L., et al., Init. Repts. DSDP, 79: Washington (U.S. Govt. Printing Office), 621-649.

Boillot, G., Winterer, E. L., Meyer, A., Applegate, J., Baltuck, M., Bergen, J. A., Comas, M. C., Davies, T. A., Dunham, T., Evans, C. A., Girardeau, J., Goldberg, D., Haggerty, J., Jansa, L. F., Johnson, J. A., Kasahara, J., Loreau, J.-P., Luna-Sierra, E., Moullade, M., Ogg, J., Sarti, M., Thurow, J., and Williamson, M. W., 1985. Résultats préliminaires de la campagne 103 du JOIDES Resolution (Ocean Drilling Program) au marge de la Galice (Espagne): sédimentation et distension pendant le 'rifting' d'une marge stable; hypothése d'une dénundation tectonique du manteau supérieur. $C$. $R$. Acad. Sci. Ser. 2, 301:627-632.

Bolkhovitina, N. A., 1956. Atlas des spores et pollens des depôts du Jurassique et du Crétacé intérieur de la depression de Vilioui. Tr. Inst. Geol. Nauk, Akad. SSR, Rev. Paleontol., 1:121-131.

Boyle, E. A., Sclater, F., and Edmond, J. M., 1976. On the marine geochemistry of cadmium. Nature, 263:42-44. 
Bralower, T. J., and Thierstein, H. R., 1984. Low productivity and slow deep-water circulation in mid-Cretaceous oceans. Geology, 12:614618.

Brenner, G. J., 1963. The spores and pollen of the Potomac group of Maryland. Bull. Md. Geol. Surv., 27:1-215.

1967. Early angiosperm pollen differentiation in the Albian to Cenomanian deposits of Delaware (U.S.A.). Rev. Palaeobot. Palynol., 1:219-227.

Brideaux, W. W., and McIntyre, D. J., 1975. Miospores and microplankton from Aptian-Albian rocks along Horton River, District of Mackenzie. Bull. Geol. Surv. Can., 252:1-85.

Bruland, K. W., 1980. Oceanographic distributions of cadmium, zinc, nickel, and copper in the North Pacific. Earth Planet. Sci. Lett., 47: 176-198.

Brumsack, H.-J., 1980. Geochemistry of Cretaceous black shales from the Atlantic Ocean (DSDP Legs 11, 14, 36 and 41). Chem. Geol., 31:1-25.

1986. The inorganic geochemistry of Cretaceous black shales (DSDP Leg 41) in comparison to modern upwelling sediments from the Gulf of California. In Summerhayes, C. P., and Shackleton, N. J. (Eds.), North Atlantic Palaeooceanography: Geol. Soc. Spec. Publ. London, 21:447-462.

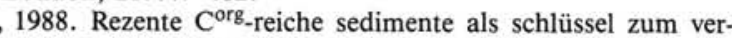
ständis fossiler Schwarzschiefer [Thesis]. Univ. Göttingen.

Brumsack, H.-J., and Gieskes, J. M., 1983. Interstitial water trace element chemistry of laminated sediments from the Gulf of California, Mexico. Mar. Chem., 14:89-106.

Brumsack, H.-J., and Thurow, J., 1986. The geochemical facies of black shales from the Cenomanian/Turonian Boundary Event. In Degens, E. T., Meyers, P. A., and Brassell, S. C. (Eds.), Biogeochemistry of Black Shales: Mitt. Geol. Palaeontol. Inst. Univ. Hamburg, 60:247265.

Bujak, J. P., and Williams, G. L., 1978. Cretaceous palynostratigraphy of offshore southeastern Canada. Bull. Geol. Surv. Can., 297:1-19.

Burger, D., 1966. Palynology of the uppermost Jurrassic and lowermost Cretaceous strata in the eastern Netherlands. Leidse Geol. Meded., $35: 209-276$.

Chamley, H., 1979. North Atlantic clay sedimentation and paleoenvironment since the Late Jurassic. In Talwani, M., Hay, W., and Ryan, W.B.F. (Eds.), Deep Drilling Results in the Atlantic Ocean: Continental Margins and Paleoenvironment: Am. Geophys. Union, Maurice Ewing Ser., 3:342-361.

Chamley, H., and Debrabant, P., 1984. Paleoenvironmental history of the North Atlantic region from mineralogical and geochemical data. Sediment. Geol., 40:51-67.

Chamley, H., and Deconinck, J.-F., 1985. Expression de l'évolution géodynamique des domaines nordatlantique et subalpin au Mésozoique supérieur, d'aprés les successions sédimentaires argileuses. $C$. R. Acad. Sci. Ser. 2, 300:1007-1012.

Christopher, R. A., 1979. Normapolles and triporate pollen assemblages from the Raritan and Magothy formations (Upper Cretaceous) of New Jersey. Palynology, 3:73-121.

Clarke, R.F.A., Davey, R. J., Sarjeant, W.A.S., and Verdier, J.-P., 1968. A note on the nomenclature of some Upper Cretaceous and Eocene dinoflagellate taxa. Taxon, 17:181-183.

Clarke, R.F.A., and Verdier, J.-P., 1967. An investigation of microplankton assemblages from the chalk of the Isle of Wright, England. Versl. Gewone. Vergad. Afd. Natuurkd., K. Ned. Akad. Wet., 24: $1-96$.

Collier, R. W., 1985. Molybdenum in the northeast Pacific Ocean. Limnol. Oceanogr., 30:1351-1354.

Collier, R. W., and Edmond, J., 1984. The trace element geochemistry of marine particulate matter. Prog. Oceanogr., 13:113-199.

Cookson, I. C., 1947. Plant microfossils from the lignites of Kerguelen Archipelago. BANZ Antart. Res. Exp. 1929-1931, Rep. A-2:127142.

Cookson, I. C., and Eisenack, A., 1958. Microplankton from Australian and New Guinea Upper Mesozoic sediments. Proc. R. Soc. Victoria, 70:19-79.

1960. Microplankton from Australian Cretaceous sediments. Micropalaeontology, 6:1-18.

1962. Additional microplankton from Australian Cretaceous sediments. Micropalaeontology, 8:485-507.

1970. Cretaceous microplankton from the Eucla Basin, western Australia. Proc. R. Soc. Victoria, 83:137-157.
Cookson, I. C., and Hughes, N. F., 1964. Microplankton from the Cambridge Greensand (mid-Cretaceous). Palaeontology, 7:37-59.

Couper, R. A., 1953. Upper Mesozoic and Cainozoic spores and pollen grains from New Zealand. N.Z. Geol. Surv. Bull., 22:1-77.

1958. British Mesozoic microspores and pollen grains. A systematic and stratigraphic study. Palaeontographica Abt. B., 103:75179.

Coutois, C., and Chamley, H., 1978. Terres rares et minéraux argileux dans le Crétacé et le Cénozoïque de la marge atlantique orientale. $C$. R. Acad. Sci. Ser. 2, 286:671-674.

Davey, R. J., 1969. Non-calcareous microplankton from the Cenomanian of England, northern France and North America, Part I. Bull. Br. Mus. Nat. Hist., Geol., 17:1-11.

1970. Non-calcareous microplankton from the Cenomanian of England, northern France and North America, Part II. Bull. Br. Mus. Nat. Hist., Geol., 18:333-397.

1979. Marine Apto-Albian palynomorphs from Holes 400A and 402A, IPOD Leg 48, northern Bay of Biscay. In Montadert, L., Roberts, D. G., et al., Init. Repts. DSDP, 48: Washington (U.S. Govt. Printing Office), 547-577.

Davey, R. J., and Verdier, J.-P., 1971. An investigation of microplankton assemblages from the Albian of the Paris Basin. Versl. Gewone Vergad. Afd. Natuurkd., K. Ned. Akad. Wet., 26:1-58.

1973. An investigation of microplankton assemblages from latest Albian (Vraconian) sediments. Rev. Esp. Micropaleontol., 5: 173-212.

1976. A review of certain non-tabulate Cretaceous hystrichosphaerid dinocysts. Rev. Palaeobot. Palynol., 22:307-335.

Davey, R. J., and Williams, R. J., 1966a. The genera Hystrichosphaera and Achomosphaera. Bull. Br. Mus. Nat. Hist., Geol., Suppl., 3: 28-52.

, 1966b. The genus Hystrichosphaeridium and its allies. Bull. Br. Mus. Nat. Hist., Geol., Suppl., 3:53-106.

1969. Generic reallocations. Bull. Br. Mus. Nat. Hist., Geol., App. Suppl., 3:4-7.

Deàk, M. H., 1963. Quelques spores striées de l'etage Aptien. Rev. Micropaleontol., 5:251-256.

Deàk, M. H., and Combaz, A., 1967. "Microfossiles organique" du Wealdien et du Cénomanien dans un sondage de Charente-Maritime. Rev. Micropaleontol., 10:69-96.

Dean, W. E., Arthur, M. A., and Claypool, G. E., 1986. Depletion of ${ }^{13} \mathrm{C}$ in Cretaceous marine organic matter: source, diagenetic, or environmental signal? In Meyers, P. A., and Mitterer, R. M. (Eds.), Deep Ocean Black Shales: Organic Geochemistry and Paleooceanographic Setting: Mar. Geol. 70:119-157.

Dean, W. E., Arthur, M. A., and Stow, D., 1984. Origin and geochemistry of Cretaceous deep-sea black shales and multicolored claystones, with emphasis on Deep Sea Drilling Project Site 530, southern Angola Basin. In Hay, W. W., Sibuet, J.-C., et al., Init. Repts. DSDP, 75: Washington (U.S. Govt. Printing Office), 819-844.

Dean, W. E., and Gardner, J. V., 1982. Origin and geochemistry of redox cycles of Jurassic to Eocene age, Cape Verde Basin (DSDP Site 367), continental margin of northwest Africa. In Schlanger, S. O., and Cita, M. B. (Eds.), Nature and Origin of Cretaceous OrganicRich Facies: London (Academic), 55-78.

Deflandre, G., 1935. Considérations biologiques sur les microorganismes d'origine planctoniques conservés dans les silex de la craie. Bull. Biol. Fr. Belg., 69:213-244.

1936. Microfossiles des silex crétacés. Premiére partie. Généralités, Flagellés. Ann. Paleontol., 25:151-191.

1937. Microfossiles des silex crétacés. Deuxiéme partie. Flagellés incertae sedis, Hystrichosphaeridés, Sarcodinés. Organismes divers. Ann. Paleontol., 26:51-103.

Deflandre, G., and Cookson, I. C., 1955. Fossil microplankton from Australian Late Mesozoic and Tertiary sediments. Aust. J. Mar. Freshwater Res., 6:242-313.

Degens, E. T., Emeis, K.-C., Mycke, B., and Wiessner, M. G., 1986. Turbidites, the principle mechanism yielding black shales in the early deep Atlantic Ocean. In Summerhayes, C. P., and Shackleton, N. J. (Eds.), North Atlantic Palaeooceanography: Geol. Soc. Spec. Publ. London, 21:361-376.

de Graciansky, P. C., Brosse, E., Deroo, G., Herbin, J. P., Montadert, L., Müller, C., Sigal, J., and Schaaf, A., 1982. Les formations d'âge crétacé de l'Atlantique nord et leur matière organique: paléogéographie et milieux de dépôt. Rev. Inst. Fr. Pet., 37:275-336. 
Deroo, G., Herbin, J. P., Roucache, J., and Tissot, B., 1979. Organic geochemistry of Cretaceous shales at DSDP Leg 47B, Site 398, Vigo Seamount, eastern Atlantic. In Sibuet, J.-C., Ryan, W.B.F., et al., Init. Repts. DSDP, 47, Pt. 2: Washington (U.S. Govt. Printing Office), 513-523.

Döring, H., 1961. Planktonartige fossilien des Jura/Kreide-Grenzbereiches der Bohrung Werle (Mecklenburg). Geol. Jahrb. Beih., 32: 110-121.

Downie, C., and Sarjeant, W.A.S., 1965. Bibliography and index of fossil dinoflagellates and acritarchs. Mem. Geol. Soc. Am., 194:1180.

Doyle, J. A., and Robbins, E. I., 1977. Angiosperm pollen zonation of the continental Cretaceous of the atlantic coastal plain and its applications to deep wells in the Salisbury embayment. Palynology, 1:4378.

Dunham, K. W., Meyers, P. A., and Dunham, P. L., 1987. Organic geochemical comparison of Cretaceous black shales and adjacent strata from DSDP Site 603, Outer Hatteras Rise. In van Hinte, J. E., Wise, S. W., et al., Init. Repts. DSDP, 93: Washington (U.S. Govt. Printing Office), $1195-1210$.

Durand, S., and Louail, J., 1976. Intérêt stratigraphique du sondage de Loudun (Vienne) pour l'étude du Cénomanien de l'Ouest de la France. C. R. Acad. Sci. Ser. 2, 283:1719-1722.

Duxbury, S., 1983. A study of dinoflagellate cysts and acritarchs from the Lower Greensand (Aptian to Lower Albian) of the Isle of Wright, southern England. Palaeontographica Abt. B, 186:18-80.

Ehrenberg, C. G., 1838. Uber das Massenverhältniss der jetzt lebenden Kiesel-Infusorien und über ein neues Infusorien-Conglomerat als Polirschiefer von Jastraba in Ungarn. Abh. Dtsch. Akad. Wiss. Berlin, Math. Naturwiss. Kl., 1836:109-135.

Einsele, G., and Wiedmann, J., 1982. Turonian black shales in the Moroccan coastal basins: first upwelling in the Atlantic Ocean? In von Rad, U., Hinz, K., Sarnthein, M., and Seibold, E. (Eds.), Geology of the Northwest African Continental Margin: Berlin (Springer), 396-414.

Eisenack, A., 1958. Mikroplankton aus dem Norddeutschen Apt. Neues. Jahrb. Geol. Palaeontol. Abh., 112:383-422.

Eisenack, A., and Kjellström, G. (Eds.), 1971. Katalog der fossilien, Dinoflagellaten, Hystrichosphären und verwandten Mikrofossilien. II, Dinoflagellaten: Stuttgart (Schweizerbart'sche Verlagsbuchhandlung).

Empson-Morin, K. M., 1984. Depth and latitude distribution of Radiolaria in Campanian (Late Cretaceous) tropical and subtropical oceans. Micropaleontology, 30:87-115.

Espitalié, J., Laporte, J. L., Madec, M., Marquis, F., Leplat, P., Paulet, J., and Boutefeu, A., 1977. Méthode rapide de charactérisation des roches méres de leur potentiel pétrolier et de leur degré d'evolution. Rev. Inst. Fr. Pet., 22:23-42.

Evitt, W. R., 1963. A discussion and proposals concerning fossil dinoflagellate, hystrichosphaeres, and acritarchs. I. Proc. Nat. Acad. Sci. USA, 49:158-164.

Fauconnier, D., 1979. Les dinoflagellés de l'Albien et du Cénomanien inférieur du bassin de Paris. Répartition stratigraphique et relations avec la nature du dépôt. Doc. B.R.G.M, 5:1-146.

1983. Etude palynologique. In Juignet, P. (Ed.), Etude de Trois Sondages dans la Région-Type du Cénomanien. La Limite Albien-Cénomanien dans la Sarthe (France): Geol. Fr., 3:193-234.

Fischer, A. G., and Arthur, M. A. 1980. Secular variations in the pelagic realm. In Cook, H. E., and Enos, P. (Eds.), Deep-Water Carbonate Environments: Spec. Publ. Soc. Econ. Paleontol. Mineral., 25:19-50.

Fonselius, S. H., 1974. Phosphorous in the Black Sea. In Degens, E. T., and Ross, D. A. (Eds.), The Black Sea: Geology, Chemistry, and Biology: AAPG Memoir, 20:144-150.

Foreman, H. P., 1977. Mesozoic radiolaria from the Atlantic Basin and its borderlands. In Swain, F. M. (Ed.), Stratigraphic Micropaleontology of Atlantic Basin and Borderlands: Amsterdam (Elsevier), 305-320.

Foucher, J.-C., 1979. Distribution stratigraphique des kystes de dinoflagellés et des acritarches dans le Crétacé supérieur du bassin de Paris et de l'Europe septentrionale. Palaeontographica Abt. B, 169:78105 .

1980. Dinoflagélles et Aeritarches. In Robaszynski, F., Amédro, F., Foucher, J.-C., Gaspard, D., Magniez-Jannin, F., Manivit, and Sornay, J., Synthese biostratigraphique de l'Aptien au Santonien du Boulonnais à partir de sept groupes paleontologiques: J. Rev. Micropaleontol., 22:195-321.

Gerlach, E., 1961. Mikrofossilien aus dem Oligozän und Miozän Nordwestdeutschlands, unter besonderer Berücksichtigung der Hystrichosphären und Dinoflagellaten. Neues Jahrb. Geol. Palaeontol. Abh., 112:143-228.

Góczán, F., Groot, J. J., Krutsch, W., and Pacltová, B., 1967. Die Gattungen des "Stemma Normapolles Pflug 1953b" Angiospermae, Neubeschreibungen und revision europäischer formen, Oberkreide bis Eozän. Palaeontol. Abh., Abt. B, 2:427-633.

Gottardi, G., and Galli, E., 1985. Natural Zeolites: Berlin (Springer).

Gray, J. (Ed.) 1965. Techniques in palynologie. In Kummel, B., and Raup, D. (Eds.), Handbook of Palaeontological Techniques: San Francisco (Freeman), 471-698.

Grim, R. E., and Güven, N., 1978. Bentonites: Amsterdam (Elsevier).

Groot, J. J., and Groot, C. R., 1962. Plant microfossils from Aptian, Albian and Cenomanian deposits of Portugal. Comun. Serv. Geol. Port., 46:133-171.

Groot, J. J., and Penny, J. S., 1960. Plant microfossils and age of nonmarine Cretaceous sediments of Maryland and Delaware. Micropaleontology, 6:225-236.

Habib, D., 1977. Comparison of Lower and middle Cretaceous palynostratigraphic zonations in the western North Atlantic. In Swain, F. M. (Ed.), Stratigraphic Micropaleontology of Atlantic Basin and Borderlands: Amsterdam (Elsevier), 341-392.

1978. Palynostratigraphy of the Lower Cretaceous section at Deep Sea Drilling Project Site 391, Blake-Bahama Basin, and its correlation in the North Atlantic. In Benson, W. E., Sheridan, R. E., et al., Init. Repts. DSDP, 44: Washington (U.S. Govt. Printing Office), $887-897$.

1979. Sedimentary origin of North Atlantic Cretaceous palynofacies. In Talwani, M., Hay, W., and Ryan, W.B.F. (Eds.), Deep Drilling Results in the Atlantic Ocean: Continental Margins and Paleoenvironment: Am Geophys. Union, Maurice Ewing Ser., 3:420437.

Habib, D., and Knapp, S. D., 1982. Stratigraphic utility of Cretaceous small acritarchs. Micropalaeontology, 28:335-371.

Haig, D. W., 1979. Global distribution patterns for mid-Cretaceous foraminiferids. J. Foraminiferal Res., 9:29-40.

Haq, B. U., Hardenbol, J., and Vail, P. A., 1987. Chronology of fluctuating sea levels since the Triassic ( 250 million years ago to present). Science, 235:1156-1167.

Hart, M. B., and Bigg, P. J., 1981. Anoxic events in the Late Cretaceous chalk seas of northwestern Europe. In Neale, J., and Brasier, M. D. (Eds.), Microfossils from Recent to Fossil Shelf Seas: Chichester (Ellis Horwood), 177-185.

Hasenboehler, B., 1981. Etude paléobotanique et palynologique de l'Albien et du Cénomanien du "Bassin Occidental Portugais" au Sud de l'accident de Nazaré (province d'Estremadure, Portugal) [Thesis]. Univ. P. et M. Curie, Paris.

Hedlund, R. W., and Norris, G., 1968. Spores and pollen grains from Fredricksburgian (Albian) strata, Marshall County, Oklahoma. Pollen et Spores, 10:129-159.

Heinrichs, H., Brumsack, H.-J., Loftfeld, N., and König, N., 1986. Verbessertes Druckaufschlussystem für biologische und anorganische Materialien. Z. Pflanzenernaehr. Bodenkd., 149:350-353.

Herbin, J. P., Magniez, F., Müller, C., and de Graciansky, P. C., 1986a. Mesozoic organic rich sediments in the South Atlantic: distribution in time and space. In Degens, E. T., Meyers, P. A., and Brassell, S. C. (Eds.), Biogeochemistry of Black Shales: Mitt. Geol. Palaeontol. Inst. Univ. Hamburg, 60:71-97.

Herbin, J. P., Masure, E., and Roucaché, J., 1987. Cretaceous formations from the lower continental rise off Cape Hatteras: organic geochemistry, dinoflagellate cysts, and the Cenomanian/Turonian Boundary Event at Sites 603 (Leg 93) and 105 (Leg 11). In Hinte, J. E., Wise, S. W., Jr., et al., Init. Repts. DSDP, 93: Washington (U.S. Govt. Printing Office), 1139-1162.

Herbin, J. P., Montadert, L., Müller, C., Gomez, R., Thurow, J., and Wiedmann, J., 1986b. Organic-rich sedimentation at the Cenomanian-Turonian Boundary in oceanic and coastal basins in the North Atlantic and Tethys. In Summerhayes, C. P., and Shackleton, N. J. (Eds.), North Atlantic Palaeooceanography: Geol. Soc. Spec. Publ. London, 21:389-422. 
Herrmann, A. G., and Knake, D., 1973. Coulometrisches Verfahren zur Bestimmung von Gesamtkarbonat- und Nichtkarbonat-Kohlenstoff in magmatischen, metamorphen und sedimentären Gesteinen. Anal. Chem., 266:196-201.

Hilbrecht, H., and Hoefs, J., 1986. Geochemical and palaeontological studies of the $\delta^{13} \mathrm{C}$ anomaly in boreal and north Tethyan Cenomanian-Turonian sediments in Germany and adjacent areas. Palaeogeogr., Palaeoclimatol., Palaeoecol., 53:169-189.

Hochuli, P., and Kelts, K., 1980. Palynology of middle Cretaceous black clay facies from Deep Sea Drilling Project Sites 417 and 418 of the western North Atlantic. In Donnelly, T., Francheteau, J., Bryan, W., Robinson, P., Flower, M., Salisbury, M., et al., Init. Repts. DSDP, 51, 52, 53, Pt. 2: Washington (U.S. Govt. Printing Office), 897-935.

Hoefs, J., 1981. Isotopic composition of the ocean-atmospheric system in the geologic past. In O'Connell, R. J., and Fyfe, W. S. (Eds.), Evolution of the Earth: Washington (Am. Geophys. Union), 110119.

Jacobs, L., Emerson, S., and Huested, S. S., 1987. Trace metal geochemistry in the Cariaco Trench. Deep Sea Res., Part A, 34:965981.

Jansa, L. F., Enos, P., Tucholke, B. E., Gradstein, F. M., and Sheridan, R. E., 1979. Mesozoic-Cenozoic sedimentary formations of the North American Basin, western North Atlantic. In Talwani, M., Hay, W., and Ryan, W.B.F. (Eds.), Deep Drilling Results in the Atlantic Ocean: Continental Margins and Paleoenvironment: Am. Geophys. Union, Maurice Ewing Ser., 3:1-57.

Jenkyns, H. C., 1980. Cretaceous anoxic events: from continents to oceans. J. Geol. Soc. London, 137:171-188.

Juignet, P., Damotte, R., Fauconnier, D., Kennedy, W. J., MagniezJannin, F., Monciardini, C., and Odin, G., 1983. Etude de trois sondages dans la région-type du Cénomanien. La limite Albien-Cénomanien dans la Sarthe (France). Geol. Fr., 3:192-234.

Kastner, M., and Stonecipher, S. A., 1978. Zeolites in pelagic sediments of the Atlantic, Pacific and Indian oceans. In Sand, L. B., and Mumpton, F. A. (Eds.), Natural Zeolites: Oxford (Pergamon), 199220.

Katz, B. J., and Pheifer, R. N. 1983. Characteristics of Cretaceous organic matter in the Atlantic. In Watkins, J., and Drake, C. (Eds.), Geology of Continental Margins: AAPG Memoir, 34:617-628.

Kedves, M. J., and Párdutz, A., 1983. Electron microscope investigations of the early Normapolles pollen genus Atlantopollis. Palynology, 7:153-169.

Kemp, E. M., 1970. Aptian and Albian miospores from southern England. Palaeontographica Abt. B, 131:73-143.

Kemper, E., 1987. Das kilma der Kreidezeit. Geol. Jahrb., A96:5-185.

Kotova, I. Z., 1978. Spores and pollen from Cretaceous deposits of the eastern North Atlantic Ocean, Deep Sea Drilling Project Leg 41, Sites 367 and 370. In Lancelot, Y., Seibold, E., et al., Init. Repts. DSDP, Suppl. to Vols. 38, 39, 40, and 41: Washington (U.S. Govt. Printing Office): 841-862.

Kroopnick, P. M., Margolis, S. V., and Wong, C. S., 1977. ${ }^{13} \mathrm{C}$ variations in marine carbonate sediments as indicators of the $\mathrm{CO}_{2}$ balance between the athmosphere and the oceans. In Anderson, N. A., and Malahoff, A. (Eds.), The Fate of Fossil Fuel $\mathrm{CO}_{2}$ in the Oceans: New York (Plenum), 2950-321.

Krutzch, W., 1959. Einige neue Formgattungen und Arten von sporen und pollen aus der mitteleuropäischen Oberkreide und dem Tertiär. Palaeontographica Abt. B, 105:125-157.

Kuhnt, W., Thurow, J., Wiedmann, J., and Herbin, J. P., 1986. Oceanic anoxic conditions around the Cenomanian/Turonian boundary and the response of the biota. In Degens, E. T., Meyers, P. A., and Brassell, S. C. (Eds.), Biogeochemistry of Black Shales: Mitt. Geol. Palaeontol. Inst. Univ. Hamburg, 60:205-246.

Laing, J. F., 1975. Mid-Cretaceous angiosperm pollen from Southern England and Northern France. Palaeontology, 18:775-808.

Lange, J., and Brumsack, H.-J. 1977. Total sulphur analysis in geological and biological materials by coulometric titration following combustion. Anal. Chem., 286:361-366.

Lange, J., Wedepohl, K. H., Heinrichs, H., and Grohn, E., 1977. Notes about the specific chemical composition of "black shales" from Site 367 (Leg 41). In Lancelot, Y., Seibold, E., et al., Init. Repts. DSDP, 41: Washington (U.S. Govt. Printing Office): 875-877.

Leckie, R. M., 1985. Foraminifera of the Cenomanian-Turonian Boundary Interval, Greenhorn Formation, Rock Canyon Anticline, Pueblo, Colorado. In Pratt, L. M., Kauffman, E. G., and Zelt, F. B. (Eds.),
Fine-grained deposits and biofacies of the Cretaceous Western Interior Seaway: Evidence of cyclic sedimentary processes: SEPM Field Trip Guidebook, 4:139-149.

Leine, L., 1986. Geology of the Tarfaya oil shale deposit, Morocco. Geol. Mijnbouw, 65:57-74.

Lentin, J. K., and Williams, G. L., 1973. Fossil dinoflagellates: index to genera and species. Pap. Geol. Surv. Can., 42(73).

1975. Fossil dinoflagellates: index to genera and species.

Suppl. 1. Can. J. Bot., 53:2147-2157.

1981. Fossil dinoflagellates: index to genera and species. Bedford Inst. Oceanogr. Rep., BI-R-81-12.

1985. Fossil dinoflagellates: index to genera and species. Can. Tech. Rept. Hydrogr. Ocean Sci., 60.

Lewy, Z., Kennedy, W. J., and Chancellor, G., 1984. Co-occurrence of Metoicoceras geslinianum (D'Orbigny) and Vascoceras cauvini Chudeau (Cretaceous Ammonoidea) in the southern Negev (Israel) and its stratigraphic implications. Newsl. Stratigr., 13:67-76.

Loeblich, A. R., Jr., and Loeblich, A. R., III, 1966. Index to the genera and subgenera, and sections of the pyrrhophyta. Stud. Trop. Oceanogr., 3:X-94.

Louail, J., Bellier, J. P., Damotte, R., and Durand, S., 1978. Stratigraphie du Cénomanien littoral de la marge sud-ouest du Bassin de Paris. L'exemple du sondage de Loudun. Geol. Mediterr., 5:115124.

Mangini, A., and Dominik, J., 1979. Late Quaternary sapropel on the Mediterranean ridge: U-budget and evidence for low accumulation rates. Sediment. Geol., 23:113-125.

Manheim, F. T., and Chan, K. M., 1974. Interstitial water of Black Sea sediments: new data and review. In Degens, E. T., and Ross, D. A. (Eds.), The Black Sea: Geology, Chemistry, and Biology: AAPG Memoir, 20:155-180.

Manum, S., and Cookson, I. C., 1964. Cretaceous microplankton in samples from Graham Island, Arctic Canada, collected during the second "Fram" Expedition (1898-1902). With notes on microplankton from the Hassel Formation, Ellef Ringnes Island. Schr. Norske Videnskap Akad. Oslo, Mat. Naturw. Klasse, Ny Ser., 17:1-35.

Martin, J. H., and Knauer, G. A., 1973. The elemental composition of plankton. Geochim. Cosmochim. Acta, 37:1639-1653.

Masure, E., 1984. L'indice de diversité et les dominances des "communautés" de kystes de dinoflagellés: marqueurs bathymétriques; forage 398D, croisières 47B. Bull. Soc. Geol. Fr., 26:93-111.

, in press, a. Albian to Cenomanian dinoflagellate cysts from Bahamas (Sites 627 and 635) Ocean Drilling Program, Leg 101. In Austin, J. A., Jr., Schlager, W. S., et al., Proc. ODP, Sci. Results, 101: College Station, TX (Ocean Drilling Program).

, in press, b. Nouvelle interprétation et amendation du genre Maghrebinia Below, 1981. Bull. Cent. Rech. Explor. Prod. Elf Aquitaine.

McIver, R., 1975. Hydrocarbon occurrence from JOIDES Deep Sea Drilling Project. Proc. World Pet. Congr. 9th, 269-280.

Médus, J., Boch, A., Parron, C., Lauverjat, J., and Triat, J. M., 1980. Turonian Normapolles from Portugal and southern France, correlations. Rev. Palaeobot. Palynol., 31:105-153.

Mélières, F., 1979. Mineralogy and geochemistry of selected Albian sediments from the Bay of Biscay, Deep Sea Drilling Project Leg 48. In Montadert, L., Roberts, D. G., et al., Init. Repts. DSDP, 48: Washington (U.S. Govt. Printing Office), 855-875.

Meyers, P. A., 1986. Cretaceous black shales in the Angola Basin of the South Atlantic Ocean: geochemistry, sedimentology, and paleoceanography. In Degens, E. T., Meyers, P. A., and Brassell, S. C. (Eds.), Biogeochemistry of Black Shales: Mitt. Geol. Palaeontol. Inst. Univ. Hamburg, 60:115-126.

Meyers, P. A., Brassell, S. C., and Huc, A. Y., 1984. Geochemistry of organic carbon in South Atlantic sediments from Deep Sea Drilling Project Leg 75. In Hay, W. W., Sibuet, J.-C., et al., Init. Repts. DSDP, 75: Washington (U.S. Govt. Printing Office), 967-981.

Morgan, G. E., 1979. Paleomagnetic results from DSDP Site 398. In Sibuet, J.-C., Ryan, W.B.F., et al., Init. Repts. DSDP, 47, Pt. 2: Washington (U.S. Govt. Printing Office), 599-612.

Moron, J. M., 1981. Etude palaéobotanique et palynologique du Crétacé supérieur du Bassin Occidental portugais au Nord de l'accident de Nazaré (Portugal) [Thesis]. Univ. P. et M. Curie, Paris.

1983. Evolution morphologique du genre Atlantopollis dans le Cénomanien et le Turonien du Nord du Bassin Occidental portugais. Phys. Geo., 6:41-52. 
Müller, C., Schaaf, A., and Sigal, J., 1983. Biochronostratigraphie des formations d'âge Crétacé dans les forages du DSDP dans l'océan Atlantique Nord. Premiére partie. Rev. Inst. Fr. Pet., 38:683-708. 1984. Biochronostratigraphie des formations d'âge crétacé dans les forage du DSDP dans l'océan Atlantique Nord. Deuxième partie. Rev. Inst. Fr. Pet., 39:3-23.

Mumpton, F. A., 1960. Clinoptilolite redefined. Am. Mineral., 45:351369.

Norris, G., 1967. Spores and pollen from the Lower Colorado group (Albian-?Cenomanian) of Central Alberta. Palaeontographica Abt. $B, 120: 72-115$.

Norvick, M. S., 1976. Mid-Cretaceous microplankton from Bathurst Island. In Norvick, M. S., and Burger, D. (Eds.), Palynology of the Cenomanian of Bathurst Island, Northern Territory, Australia: Bull. Bur. Miner. Resour. Geol. Geophys. Aust., 15:21-113.

Otsuka, K., 1985. Silicified sediments and silica diagenesis in the Goban Spur area of the Northeast Atlantic, Leg 80. In de Graciansky, P. C., Poag, C. W., et al., Init. Repts. DSDP, 80: Washington (U.S. Govt. Printing Office), 1081-1099.

Paden Phillips, P., and Felix, C., 1971a. A study of Lower and middle Cretaceous spores and pollen from the southeastern United States. I. Spores. Pollen Spores, 13:279-348.

1971b. A study of Lower and middle Cretaceous spores and pollen from the southeastern United States. II. Pollen. Pollen Spores, 13:447-473.

Pierce, A. L., 1961. Lower Upper Cretaceous plant microfossils from Minnesota. Bull. Minn. Geol. Surv., 42:1-86.

Pilipchuk, M. F., and Volkov, I. I., 1974. Behavior of molybdenum in processes of sediment formation and diagenesis in the Black Sea. In Degens, E. T., and Ross, D. A. (Eds.), The Black Sea: Geology, Chemistry, and Biology: AAPG Memoir, 20:542-553.

Pocock, S.A.J., 1962. Microfloral analysis and age determination of strata at the Jurassic boundary in the western Canada plains. $\mathrm{Pa}$ laeontographica Abt. B, 111:1-95.

1964. Pollen and spores of the Chlamydospermidae and Schizaeaceae from Upper Mannville strata of the Saskatoon area of Saskatchewan. Grana Palynol., 5:129-209.

Pomerol, B., 1983. Geochemistry of the late Cenomanien-early Turonian chalks of the Paris Basin: manganese and carbon isotopes in carbonates as paleooceanographic indicators. Cretaceous Res., 4: $85-93$.

Potonié, R., 1960. Synopsis der Gattungen der Sporae dispersae. III Nachträge Sporites USW. Geol. Jahrb. Beih., 39.

Pratt, L. M., 1984. Influence of paleoenvironmental factors on preservation of organic matter in middle Cretaceous Greenhorn Formation, Pueblo, Colorado. AAPG Bull., 68:1146-1159.

Pratt, L. M., and Threlkeld, C. N., 1984. Stratigraphic significance of ${ }^{13} \mathrm{C} /{ }^{12} \mathrm{C}$ ratios in mid-Cretaceous rocks of the Western Interior, U.S.A. In Stott, D. F., and Glass, D. J. (Eds.), The Mesozoic of Middle North America: Mem. Can. Soc. Pet. Geol., 9:305-312.

Riech, V., and von Rad, U., 1979. Silica diagenesis in the Atlantic Ocean: diagenetic potential and transformations. In Talwani, M., Hay, W., and Ryan, W.B.F. (Eds.), Deep Drilling Results in the Atlantic Ocean: Continental Margins and Paleoenvironment: Am. Geophys. Union, Maurice Ewing Ser., 3:315-340.

Robaszynski, F., Alcayde, G., Amedro, F., Badillet, G., Damotte, R., Foucher, J.-C., Jardine, S., Legoux, O., Manivit, H., Monciardini, C., and Sornay, J., 1982. Le Turonien de la région-type: Saumurois et Touraine. Stratigraphie, biozonations, sédimentologie. Bull. Cent. Rech. Explor. Prod. Elf Aquitaine, 6:119-225.

Robaszynski, F., and Caron, M., 1979. Atlas de foraminifères planktoniques du Crétacé moyen (mer boréale et Téthys). Cah. Micropaleontol., 1.

Rona, E., and Joensu, O., 1974. Uranium geochemistry in the Black Sea. In Degens, E. T., and Ross, D. A. (Eds.), The Black Sea: Geology, Chemistry, and Biology: AAPG Memoir, 20:542-553.

Ross, N. E., 1949. On a Cretaceous pollen and spore bearing clay deposit of Sadnia (a preliminary report). Bull. Soc. Geol. Univ. Uppsala, 34:25-42.

Rouse, G. E., 1959. Plant microfossils from Kootenay coal measures strata of British Columbia. Micropaleontology, 5:303-324.

Sanfilippo, A., and Riedel, W. R., 1985. Cretaceous radiolaria. In Bolli, H. M., Saunders, J. B., Perch-Nielsen, K. (Eds.), Plankton Stratigraphy: Cambridge (Cambridge Univ. Press), 573-630.
Sarjeant, W.A.S., 1966. Further dinoflagellate cysts from the Speeton Clay. Bull. Br. Mus. Nat. Hist., Geol., Suppl., 3:199-214. 1969. Taxonomic changes. Bull. Br. Mus. Nat. Hist., Geol. Suppl., 3:7-15. Press).

Schaaf, A., 1985. Un nouveau canevas biochronologique du Crétacé inférieur et moyen: les biozones à radiolaires. Sci. Geol., Bull., 38: 227-269.

Schlanger, S. O., Arthur, M. A., Jenkyns, H. C., and Scholle, P. A., 1987. The Cenomanian-Turonian Anoxic Event, I: stratigraphy and distribution of organic carbon-rich beds and the marine $\delta^{13} \mathrm{C}$ excursion. In Brooks, J., and Fleet, A. (Eds.), Marine Petroleum Source Rocks: Geol. Soc. Spec. Publ. London, 26:371-399.

Schlanger, S. O., and Cita, M. B., 1982. Introduction. In Schlanger, S. O., and Cita, M. B. (Eds.), Nature and Origin of Cretaceous Organic-Rich Facies: London (Academic), 1-6.

Schlanger, S. O., and Jenkyns, H. C., 1976. Cretaceous anoxic events: causes and consequences. Geol. Mijnbouw, 55:179-184.

Scholle, P. A., and Arthur, M. A., 1980. Carbon isotopic fluctuations in Cretaceous pelagic limestones: potential stratigraphic and petroleum exploration tool. AAPG Bull., 64:67-87.

Shipboard Scientific Party, 1979. Site 398. In Sibuet, J.-C., Ryan, W.B.F., et al., Init. Repts. DSDP, 47, Pt. 2: Washington (U.S. Govt. Printing Office), $25-233$.

1986. Site 585. In Moberly, R., Schlanger, S. O., et al., Init. Repts. DSDP, 89: Washington (U.S. Govt. Printing Office), 29-155.

, 1987a. Introduction, objectives, and principal results: Ocean Drilling Program Leg 103, west Galicia margin. In Boillot, G., Winterer, E. L., et al., Proc. ODP, Init. Repts., 103: College Station, TX (Ocean Drilling Program), 3-17.

1987b. Site 641. In Boillot, G., Winterer, E. L., et al., Proc. ODP, Init. Repts., 103: College Station, TX (Ocean Drilling Program), 571-649.

Sigal, J., 1979. Chronostratigraphy and ecostratigraphy of Cretaceous formations recovered on DSDP Leg 47B, Site 398. In Sibuet, J.-C., Ryan, W.B.F., et al., Init. Repts. DSDP, 47, Pt. 2: Washington (U.S. Govt. Printing Office), 287-326.

Singh, C., 1964. Microflora of the Lower Cretaceous Mannville Group, east Central Alberta. Bull. Alberta Res. Counc., 15:1-239.

1971. Lower Cretaceous microfloras of the Peace River area, northwestern Alberta. Publ. Alberta Res. Counc., 28.

1983. Cenomanian microfloras of the Peace River area, northwestern Alberta. Bull. Alberta Res. Counc., 44:1-322.

Skarby, A., 1978. Optical properties of fossil Schizaea spores from the Upper Cretaceous of Scania. Grana, 17:111-123.

Sole de Porta, N., 1978. Palinologia de dos secciones del Cenomaniense de los alrededores de Oviedo (Espana). Palinologia (num. extr.) 1: 435-441.

Spencer, D. W., Brewer, P. G., and Sachs, P. L., 1972. Aspects of the distribution and trace element composition of suspended matter in the Black Sea. Geochim. Cosmochim. Acta, 36:71-86.

Stein, R., Rullkötter, J., and Welte, D. H., 1986. Accumulation of organic carbon-rich sediments in the Late Jurassic and Cretaceous Atlantic Ocean-a synthesis. Chem. Geol., 56:1-32.

Stonecipher, S. A., 1976. Origin, distribution and diagenesis of phillipsite and clinoptilolite in deep-sea sediments. Chem. Geol., 17:307318.

1978. Chemistry of deep-sea phillipsite, clinoptilolite and host sediments. In Sand, L. B., and Mumpton, F. A. (Eds.), Natural Zeolites: Oxford (Pergamon), 221-234.

Stover, L. E., and Evitt, W. R., 1978. Analyses of pre-Pleistocene, organic-walled dinoflagellates. Stanford Univ. Publ., Geol. Sci., 15:1300.

Summerhayes, C. P., 1981. Organic facies of middle Cretaceous black shales in the deep North Atlantic. AAPG Bull., 65:2364-2380.

Taugourdeau-Lantz, J., Azéma, C., Hasenboehler, B., Masure, E., and Moron, J. M., 1982. Evolution des domaines continentaux et marins de la marge portugaise (Leg 47B, Site 398D) au cours du Crétacé: essai d'interprétation par l'analyse palynologique comparée. Bull. Soc. Geol. Fr., 24:447-459.

Thiergart, F., 1954. Einige sporen und pollen aus einer Cenoman Kohle Südfrankreichs und Vergleiche mit gleichaltrigen Ablagerungen. Geol. J., 3:548-559. 
Thurow, J., 1987. Die kretazischen Turbiditserien im Gibraltarbogen: Bindeglied zwischen atlantischer und tethyaler Entwicklung [Ph.D. dissert.] Univ. Tübingen.

Thurow, J., and Kuhnt, W., 1986. Mid-Cretaceous of the Gibraltar Arch Area. In Summerhayes, C. P., and Shackleton, N. J. (Eds.), North Atlantic Palaeooceanography: Geol. Soc. Spec. Publ. London, 21: 423-444.

Thurow, J., Kuhnt, W., and Wiedmann, J., 1982. Zeitlicher und paläogeographischer Rahmen der Phthanit- und black-shale sedimentation in Marokko. Neues Jahrb. Geol. Palaeontol. Abh., 165:147176.

Valensi, L., 1955. Sur quelque microorganismes des silex crétacés du Magdalénien de Saint-Amand (Cher). Bull. Soc. Geol. Fr., 6:35-40.

Veizer, J. B., Holsar, W. T., and Wilgus, C. K., 1980. Correlation of $\mathrm{Cl}_{3}$ / $\mathrm{C}^{12}$ and $\mathrm{S}^{34} / \mathrm{S}^{32}$ secular variations. Geochim. Cosmochim. Acta, 44 : 579-587.

Waples, D. W., 1983. Reappraisal of anoxia and organic richness, with emphasis on Cretaceous of North Atlantic. AAPG Bull., 67:963978.

Wetzel, O., 1932. Die typen der baltischen Geschiebefeuersteine, beurteilt nach ihrem gehalt an mikrofossilien. Z. Geschiebeforsch. Flachldgeol., 8:129-146.

1933. Die in organischer substanz erhaltenen mikrofossilien des baltischen Kreide-Feuersteins mit einem sediment-petrographischen und stratigraphischen Anhang. Palaeontographica Abt. A, 77: 141-188.

Weyland, H., and Greifeld, G., 1953. Uber strukturbietende Blätter und pflanzliche mikrofossilien aus den untersenonen Tonen der Gegend von Quedlinburg. Palaeontographica Abt. B, 95:30-32.
White, H. H., 1842. On fossil Xanthidia. Micros., 11:35-40.

Wiedmann, J., Butt, A., and Einsele, G., 1978. Vergleich von marokkanischen Kreide-Küstenaufschlüssen und Tiefseebohrungen (DSDP): stratigraphie, paläoenvironment und subsidenz an einem passiven kontinentalrand. Geol. Rdsch., 67:454-508.

1982. Cretaceous stratigraphy, environment, and subsidence history at the Moroccan continental margin. In von Rad, U., Hinz, K., Sarnthein, M., and Seibold, E. (Eds.), Geology of the Northwest African Continental Margin: Berlin (Springer), 366-395.

Williams, G. L., 1975. Dinoflagellate and spores stratigraphy of the Mesozoic-Cenozoic, offshore eastern Canada. Pap. Geol. Surv. Can., 2(74-30):107-161.

Williams, G. L., and Bujak, J. P., 1985. Mesozoic and Cenozoic dinoflagellates. In Bolli, H. M., Saunders, J. B., and Perch-Nielsen, K. (Eds.), Plankton Stratigraphy: Cambridge (Cambridge Univ. Press), 847-964.

Wolfart, R., 1982. Cretaceous radiolaria from the northwest African continental margin. In von Rad, U., et al. (Eds.), Geology of the Northwest African continental margin: Berlin (Springer), 345-365.

Yun, H.-S., 1981. Dinoflagellaten aus der Oberkreide (Santon) von Westfalen. Palaeontographica Abt. B, 177:1-89.

Zimmerman, H. B., Boersma, A., and McCoy, F. W., 1987. Carbonaceous sediments and paleoenvironment of the Cretaceous South Atlantic. In Brooks, J., and Fleet, A. (Eds.), Marine Petroleum Source Rocks: Geol. Soc. Spec. Publ. London, 26:271-286.

Date of initial receipt: 5 August 1987

Date of acceptance: 17 December 1987

Ms 103B-172 


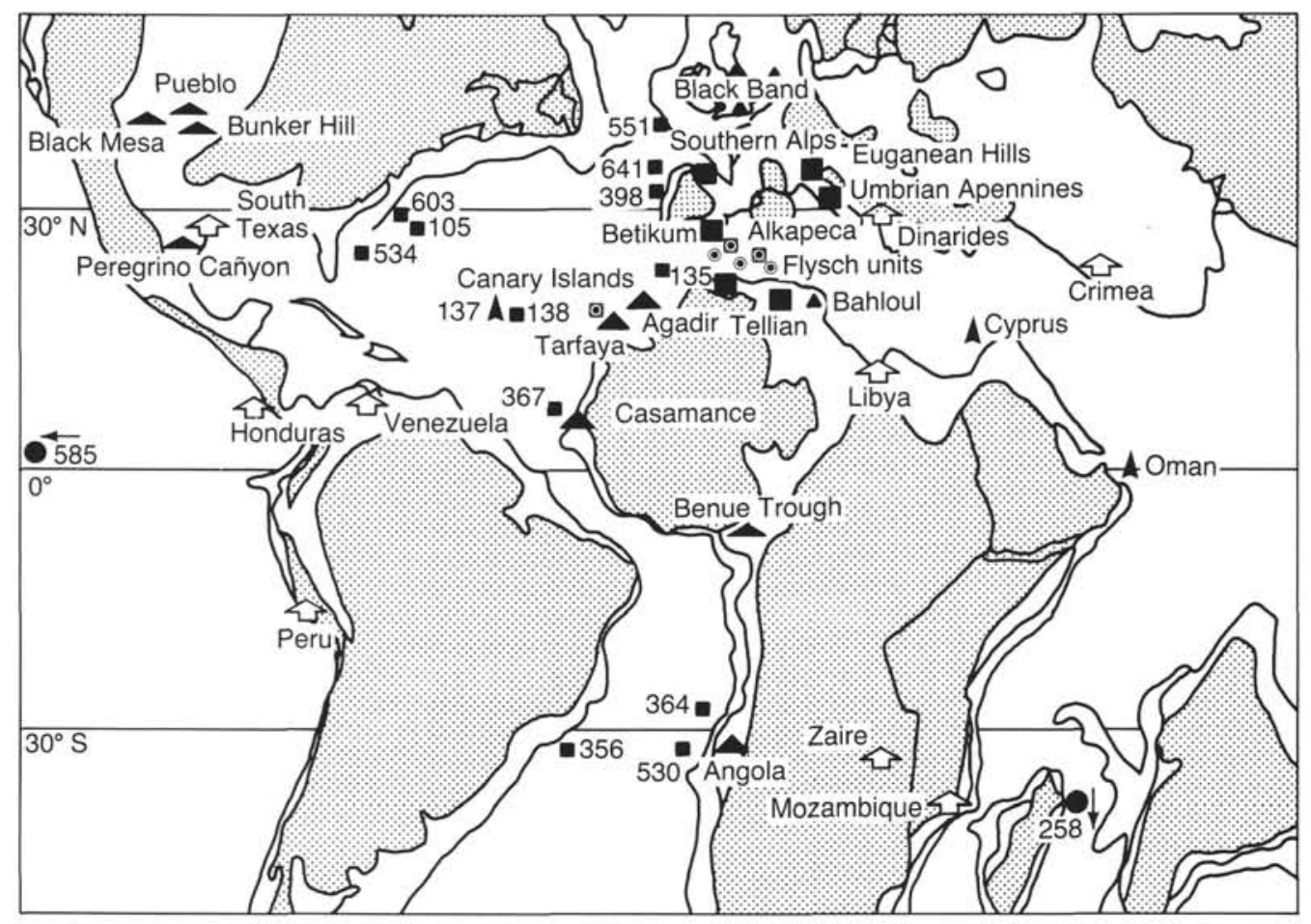

Figure 16. Occurrences of the CTBE associated with black shales from DSDP/ODP sites and selected land outcrops with studied CTBE sections. Paleogeographic map at $80 \mathrm{Ma}$ with $30^{\circ}$ paleolatitude lines (Barron et al., 1981). Symbols are as follows: solid vertical arrow = occurrences on oceanic crust (DSDP Site 137, ?Cyprus, and ?Oman); large and small solid squares = occurrences in intramarginal basins, half-grabens, or on plateaus (DSDP Sites 105, 135, 138, 356, 364, 367, 398, 530, 534, 551 and 603; ODP Site 641; Southern Alps; Euganean Hills, northern Italy; Umbrian Apennines, central Italy; Subbetic; Penibetic, southern Spain; and Ulzama Basin, northern Spain); open squares around solid circles = occurrences on outer margins or slopes (Alkapeca [?terranes in the western Tethys] and ?Fuerteventura, Canary Islands); open circles around solid circles = occurrences in deep-sea fans (Massylian and Mauretanian flysch of the Gibraltar Arch area, northern Africa and southern Italy); flattened solid triangles = occurrences in interacratonic basins (?embryonic rifts) (Western Interior Basin localities in the U.S. and Canada and Benue Trough, Nigeria); large solid triangles = occurrences in coastal basins (Agadir, Tarfaya, Senegal [Casamance], and Angola basins of northwest Africa); small solid triangles = occurrences in epicontinental seas with starved depressions ("Bahloul Formation" of Tunisia and "Black Band" of England, North Sea, and northern Germany); large solid circles = occurrences in the Indian and Pacific oceans (DSDP Sites 258 [Naturaliste Plateau; Schlanger et al., 1987] and 585 [Mariana Basin; Shipboard Scientific Party, 1986]); open arrow = mid-Cretaceous shales with tentative assignment to the CTBE (Honduras, Venezuela, Peru, Zaire, Mozambique, Libya, Crimea, Dinarides, and southern Texas). 
APPENDIX A

Trace Metal Content of Sediments Around the CTBE at Hole 641A

\begin{tabular}{|c|c|c|c|c|c|c|c|c|c|c|c|c|c|c|c|}
\hline & $3 \mathrm{X}, \mathrm{CC}$ & $4 \mathrm{X}, \mathrm{CC}$ & $5 \mathrm{X}, \mathrm{CC}$ & $\begin{array}{c}6 \mathrm{X}-7 \\
(11-14 \mathrm{~cm})\end{array}$ & $\begin{array}{c}6 \mathrm{X}-7 \\
(15-18 \mathrm{~cm})\end{array}$ & $\begin{array}{c}6 \mathrm{X}-7, \\
(26-29 \mathrm{~cm})\end{array}$ & $\begin{array}{c}6 \mathrm{X}-7 \\
(31-33 \mathrm{~cm})\end{array}$ & $\begin{array}{c}6 \mathrm{X}, \mathrm{CC} \\
(0-3 \mathrm{~cm})\end{array}$ & $\begin{array}{c}6 \mathrm{X}, \mathrm{CC} \\
(8-11 \mathrm{~cm})\end{array}$ & $\begin{array}{c}6 \mathrm{X}, \mathrm{CC} \\
(18-21 \mathrm{~cm})\end{array}$ & $\begin{array}{c}6 \mathrm{X}, \mathrm{CC} \\
(21-24 \mathrm{~cm})\end{array}$ & $\begin{array}{c}6 \mathrm{X}, \mathrm{CC} \\
(24-27 \mathrm{~cm})\end{array}$ & $\begin{array}{c}6 \mathrm{X}, \mathrm{CC} \\
(27-30 \mathrm{~cm})\end{array}$ & $\begin{array}{c}6 \mathrm{X}, \mathrm{CC} \\
(35-37 \mathrm{~cm})\end{array}$ & $7 \mathrm{X}, \mathrm{CC}$ \\
\hline $\mathrm{Ag}(\mathrm{ppm})$ & 0.24 & 0.1 & 0.1 & 0.35 & 0.33 & 6.5 & 6.9 & 4.7 & 3.8 & 1.4 & 0.25 & 0.23 & 0.27 & 0.22 & 0.33 \\
\hline As (ppm) & 5. & 5. & 5. & 5. & 5. & 50. & 120. & 110. & 140. & 210. & 5. & 5. & 5. & 5. & 5. \\
\hline $\mathrm{Ba}(\mathrm{ppm})$ & 310. & 260. & 365. & 245. & 590. & 1015. & 1700. & 1455. & 1350. & 575. & 185. & 170. & 286. & 440. & 760. \\
\hline $\mathrm{Cd}(\mathrm{ppm})$ & 0.1 & 0.1 & 0.1 & 0.1 & 0.1 & 18.5 & 133. & 86. & 28. & 5. & 0.1 & 0.1 & 0.12 & 0.1 & 0.1 \\
\hline Co (ppm) & 52. & 46. & 42. & 19. & 15.6 & 235. & 600. & 559. & 431. & 515. & 71. & 36. & 35. & 21. & 23. \\
\hline $\mathrm{Cr}(\mathrm{ppm})$ & 88. & 91. & 99. & 77. & 86. & 145. & 168. & 142. & 139. & 109. & 73. & 73. & 71. & 60. & 71. \\
\hline Cs (ppm) & 13.7 & 12.6 & 12.0 & 15.1 & 14.8 & 11.9 & 9.7 & 10.4 & 10.3 & 8.7 & 12.0 & 10.4 & 7.6 & 7.4 & 6.0 \\
\hline $\mathrm{Cu}(\mathrm{ppm})$ & 69. & $102 . ?$ & 70. & 76. & 80. & 710. & 365. & 330. & 200. & 160. & 36. & 77. & 46. & 22. & 118. \\
\hline $\mathrm{Hf}(\mathrm{ppm})$ & 3.5 & 2.9 & 3.9 & 4.5 & 4.3 & 3.8 & 2.2 & 2.1 & 2.4 & 2.2 & 2.7 & 2.8 & 2.6 & 2.7 & 2.2 \\
\hline $\mathrm{Mn}(\mathrm{ppm})$ & 2460 . & 4515. & 4565. & 450. & 390. & 319. & 279. & 300. & 680. & 1630. & 3550. & 1950. & 2680 . & 2950 . & 1200. \\
\hline Mo (ppm) & 1.8 & 2.1 & 2.3 & 4. & 2.9 & 195. & 1040. & 970. & 2500 . & 5050. & 45. & 12. & 18. & 18. & 0.9 \\
\hline $\mathrm{Ni}(\mathrm{ppm})$ & 104. & 107. & 97. & 66. & 51. & 240. & 590. & 555. & 415. & 520. & 81. & 56. & 49. & 40. & 86. \\
\hline $\mathrm{Pb}(\mathrm{ppm})$ & 37. & 39. & 45. & 24. & 90. & 147. & 114. & 88. & 54. & 27.3 & 16.4 & 21.1 & 16.8 & 15.4 & 24.1 \\
\hline $\mathrm{Rb}(\mathrm{ppm})$ & 159. & 144. & 161. & 179. & 167. & 141. & 110. & 128. & 112. & 106. & 180. & 153. & 95. & 93. & 78. \\
\hline $\mathrm{Sb}(\mathrm{ppm})$ & 1.2 & 2.8 & 2.7 & 2.9 & 3.1 & 12.3 & 55. & 45. & 43. & 18.7 & 2.7 & 0.8 & 1.2 & 00.6 & 1.0 \\
\hline $\mathrm{Sc}(\mathrm{ppm})$ & 18. & 15.5 & 19. & 17. & 16. & 15. & 10.5 & 11. & 10.5 & 10. & 13.5 & 14. & 11.5 & 10.5 & 11. \\
\hline Sr (ppm) & 78. & 84. & 94. & 102. & 102. & 105. & 140. & 105. & 140. & 159. & 128. & 221. & 360. & 430. & 495. \\
\hline $\mathrm{Ta}(\mathrm{ppm})$ & 1.8 & 2.0 & 2.5 & 2.0 & 2.4 & 1.6 & 1.5 & 1.1 & 1.4 & 1.0 & 1.8 & 1.5 & 1.4 & 1.2 & 0.9 \\
\hline Th (ppm) & 14. & 10. & 12. & 18. & 14. & 13. & 7.8 & 10.5 & 7.1 & 10. & 9.9 & 11. & 7.3 & 8.9 & 6.5 \\
\hline $\mathrm{TI}$ (ppm) & & & & 0.2 & 0.2 & 1.1 & 3.1 & 2.5 & 3.5 & 5.2 & 0.2 & 0.2 & 0.25 & 0.35 & \\
\hline $\mathrm{U}(\mathrm{ppm})$ & 1.2 & 1.4 & 1.4 & 1.5 & 1.5 & 32. & 81. & 82. & 90. & 114. & 8.2 & 3.0 & 3.2 & 2.2 & 1.5 \\
\hline $\mathrm{V}(\mathrm{ppm})$ & 150. & 140. & 129. & 140. & 115. & 710. & 1350. & 1140. & 1060. & 580. & 95. & 76. & 74. & 67. & 90. \\
\hline $\mathrm{Zn}(\mathrm{ppm})$ & 129. & 135. & 107. & 89. & 80. & 1150. & 6500 . & 8175. & 17170 . & 1335. & 108. & 101. & 106. & 89. & 101. \\
\hline $\mathrm{Al}(\%)$ & 10.76 & 10.25 & 9.79 & 9.79 & 9.66 & 8.17 & 6.43 & 6.56 & 6.62 & 6.09 & 7.92 & 7.31 & 6.11 & 5.79 & 6.11 \\
\hline $\mathrm{Ca}(\%)$ & 0.135 & 0.21 & 0.315 & 0.34 & 0.34 & 0.39 & 0.24 & 0.32 & 0.29 & 0.77 & 3.52 & 6.00 & 9.70 & 11.30 & 11.60 \\
\hline $\mathrm{Fe}(\%)$ & 5.29 & 5.27 & 5.40 & 5.27 & 4.53 & 3.78 & 3.54 & 3.39 & 3.38 & 4.32 & 3.24 & 2.91 & 2.57 & 2.38 & 2.71 \\
\hline $\mathrm{K}(\%)$ & 3.16 & 3.28 & 2.73 & 3.27 & 3.34 & 3.13 & 2.97 & 3.13 & 3.08 & 2.81 & 2.83 & 2.49 & 2.22 & 2.07 & 1.63 \\
\hline $\mathrm{Mg}(\%)$ & 1.01 & 0.91 & 1.05 & 1.18 & 1.16 & 1.28 & 0.83 & 0.93 & 0.99 & 0.90 & 1.38 & 1.50 & 1.25 & 1.11 & 1.23 \\
\hline $\mathrm{Na}(\%)$ & 1.10 & 1.16 & 1.28 & 1.28 & 1.32 & 1.34 & 1.55 & 1.45 & 1.44 & 1.38 & 1.36 & 1.32 & 1.12 & 1.18 & 1.23 \\
\hline $\mathrm{P}(\%)$ & 0.069 & 0.059 & 0.078 & 0.077 & 0.079 & 0.053 & 0.030 & 0.056 & 0.056 & 0.288 & 0.033 & 0.012 & 0.019 & 0.011 & 0.008 \\
\hline$S(\%)$ & 0.017 & 0.034 & 0.012 & 0.032 & 0.043 & 1.13 & 3.53 & 3.04 & 3.77 & 4.29 & 0.12 & 0.075 & 0.12 & 0.10 & 0.066 \\
\hline Si $(\%)$ & 24.4 & 25.3 & 23.4 & 26.0 & 26.4 & 24.6 & 21.0 & 21.6 & 22.3 & 19.4 & 23.4 & 22.0 & 20.0 & 17.7 & 17.9 \\
\hline $\mathrm{Ti}(\%)$ & 0.54 & 0.53 & 0.62 & 0.46 & 0.50 & 0.50 & 0.26 & 0.25 & 0.29 & 0.25 & 0.34 & 0.34 & 0.29 & 0.23 & 0.25 \\
\hline TOC $(\%)$ & 0.12 & 0.13 & 0.11 & 0.15 & 0.17 & 3.25 & 9.78 & 9.44 & 9.14 & 11.04 & 0.23 & 0.21 & 0.38 & 0.29 & 0.33 \\
\hline $\mathrm{La}(\mathrm{ppm})$ & 33.4 & 36.5 & 43.8 & 43.4 & 44.3 & 32.3 & 22.2 & 22.1 & 23.2 & 29.8 & 32.3 & 33.1 & 29.9 & 26.2 & 26.1 \\
\hline $\mathrm{Ce}(\mathrm{ppm})$ & 85. & 89. & 107. & 109. & 102. & 73. & 54. & 60. & 56. & 85. & 66. & 68. & 55. & 48. & 48. \\
\hline Sm (ppm) & 7.3 & 8.4 & 9.6 & 10.1 & 10.1 & & & & & & & 6.8 & 6.5 & 5.3 & 4.9 \\
\hline $\mathrm{Eu}(\mathrm{ppm})$ & 1.55 & 1.72 & 2.11 & 2.16 & 2.21 & 1.55 & 0.82 & 0.89 & 0.68 & 1.18 & 1.33 & 1.50 & 1.39 & 1.13 & 1.08 \\
\hline $\mathrm{Tb}(\mathrm{ppm})$ & 1.07 & & & 1.44 & & 1.03 & & 0.64 & & 1.04 & & 1.11 & & 0.74 & \\
\hline $\mathrm{Yb}$ (ppm) & 2.35 & 2.91 & 3.68 & 3.57 & 4.02 & 2.61 & 2.10 & 1.36 & 1.67 & 1.84 & 2.52 & 1.84 & 2.08 & 1.85 & 2.18 \\
\hline Lu (ppm) & 0.32 & 0.35 & 0.43 & 0.45 & 0.44 & & & & & & & 0.54 & 0.55 & 0.46 & 0.39 \\
\hline
\end{tabular}


APPENDIX B

List of Palynomorph Samples at Site 641

\begin{tabular}{|c|c|c|c|}
\hline Sample & Unit & Color & Palynomorphs ${ }^{\mathrm{a}}$ \\
\hline $641 \mathrm{~A}-3 \mathrm{X}-1,119-120 \mathrm{~cm}$ & A & Red & DINOS PO/SPO \\
\hline $3 \mathrm{X}-1,121-122 \mathrm{~cm}$ & A & Red & DINOS PO/SPO \\
\hline $3 \mathrm{X}-2,139-141 \mathrm{~cm}$ & A & Red & DINOS PO/SPO \\
\hline $3 \mathrm{X}, \mathrm{CC}(12-14 \mathrm{~cm})$ & A & Red & DINOS PO/SPO \\
\hline $4 X-1,19-21 \mathrm{~cm}$ & A & Red & DINOS PO/SPO \\
\hline $4 X, C C(26-28 \mathrm{~cm})$ & A & Red & DINOS PO/SPO \\
\hline $5 X-1,67-69 \mathrm{~cm}$ & A & Red & DINOS PO/SPO \\
\hline $5 \mathrm{X}-2,67-69 \mathrm{~cm}$ & A & Red & DINOS PO/SPO \\
\hline $6 \mathrm{X}-1,92-94 \mathrm{~cm}$ & A & Red & DINOS PO/SPO \\
\hline $6 \mathrm{X}-2,88-90 \mathrm{~cm}$ & A & Red & DINOS PO/SPO \\
\hline $6 \mathrm{X}-3,86-88 \mathrm{~cm}$ & A & Red & DINOS PO/SPO \\
\hline $6 \mathrm{X}-4,55-57 \mathrm{~cm}$ & A & Red & DINOS PO/SPO \\
\hline $6 \mathrm{X}-5,55-57 \mathrm{~cm}$ & A & Red & DINOS PO/SPO \\
\hline $6 \mathrm{X}-6,55-57 \mathrm{~cm}$ & A & Red & DINOS PO/SPO \\
\hline $6 \mathrm{X}-7,11-14 \mathrm{~cm}$ & A & Red & DINOS PO/SPO \\
\hline $6 \mathrm{X}-7,15-18 \mathrm{~cm}$ & $\mathrm{~A} / \mathrm{B}$ & Red/green & DINOS PO/SPO \\
\hline $6 \mathrm{X}-7,26-29 \mathrm{~cm}$ & $\mathrm{~B} / \mathrm{C}$ & Black/green & DINOS PO/SPO \\
\hline $6 \mathrm{X}-7,31-33 \mathrm{~cm}$ & $\mathrm{C}$ & Black & DINOS PO/SPO \\
\hline $6 \mathrm{X}, \mathrm{CC}(0-3 \mathrm{~cm})$ & C & Black & DINOS PO/SPO \\
\hline $6 \mathrm{X}, \mathrm{CC}(8-11 \mathrm{~cm})$ & C & Black & DINOS PO/SPO \\
\hline $6 \mathrm{X}, \mathrm{CC}(18-21 \mathrm{~cm})$ & $\mathrm{C} / \mathrm{D}$ & Black/green & DINOS PO/SPO \\
\hline $6 \mathrm{X}, \mathrm{CC}(21-24 \mathrm{~cm})$ & D & Dark green & DINOS PO/SPO \\
\hline $6 \mathrm{X}, \mathrm{CC}(24-27 \mathrm{~cm})$ & D & Dark green & DINOS PO/SPO \\
\hline $6 \mathrm{X}, \mathrm{CC}(27-30 \mathrm{~cm})$ & E & Greenish gray & DINOS PO/SPO \\
\hline $6 \mathrm{X}, \mathrm{CC}(35-37 \mathrm{~cm})$ & E & Greenish gray & DINOS PO/SPO \\
\hline $7 \mathrm{X}-1,84-86 \mathrm{~cm}$ & $\mathrm{E}$ & Greenish gray & DINOS PO/SPO \\
\hline $7 X-3,24-26 \mathrm{~cm}$ & E & Greenish gray & DINOS PO/SPO \\
\hline $7 \mathrm{X}-4,88-90 \mathrm{~cm}$ & E & Greenish gray & DINOS PO/SPO \\
\hline $7 \mathrm{X}-5,21-23 \mathrm{~cm}$ & $\mathrm{E}$ & Greenish gray & DINOS PO/SPO \\
\hline $7 \mathrm{X}, \mathrm{CC}(18-20 \mathrm{~cm})$ & E & Greenish gray & DINOS PO/SPO \\
\hline $641 C-1 \mathrm{R}-3,27-30 \mathrm{~cm}$ & & & $\mathrm{PO} / \mathrm{SPO}$ \\
\hline $4 \mathrm{R}-2,142-144 \mathrm{~cm}$ & & & $\mathrm{PO} / \mathrm{SPO}$ \\
\hline
\end{tabular}

APPENDIX C

Dinoflagellate Taxonomic Notes

The taxonomy is divided into two parts. The first part provides morphological descriptions of species with new combination and remarks (this Appendix). The second part lists all dinoflagellate cysts and acritarcha encountered during this study in alphabetical order, with references to plates and the range chart (Appendix D).

Class DINOPHYCEAE Fritsch, 1929

Order PERIDINIALES Haeckel, 1894

Genus KIOKANSIUM (Stover and Evitt, 1978) Duxbury, 1983

Type species. Kiokansium polypes (Cookson and Eisenack, 1962) ( = Hystrychosphaeridium recurvatum subsp. polypes Cookson and Eisenack, 1962, p. 491, pl. 4, figs. 11-13; Below, 1982, p. 16.

\section{Kiokansium sp. GAL}

$$
\text { (Pl. 7, Fig. 6) }
$$

Description. Skolochorate dinoflagellate cyst with ellipsoidal elongated central body. Numerous processes, nontabular, solid with slender or large shafts and closed tips, expanded distally (funnel). The funnel is perforated and its rims are fringed with numerous thin spines. Paracingulum indicated by transverse aligment of processes. Autophragm slightly granular. Paratabulation gonyaulacoid. Precingular archeopyle 2P(3-4), opercular pieces free.

Comparison. Kiokansium sp. GAL differs by its perforated funnel fringed with spines. The other species have a distal process part slightly flared, not perforated, and fringed with spines or simply branched.

Remarks. Few individuals are encountered to create a new species.

Dimensions. Central body: length $55-56 \mu \mathrm{m}$, width $40-35 \mu \mathrm{m}$. Processes: length $17-12 \mu \mathrm{m}$. (Two specimens, well preserved.)

Occurrences. See Figure 1, no. 50: Samples 103-641A-7X-3, 24-26 $\mathrm{cm}$, to $103-641 \mathrm{~A} 6 \mathrm{X}, \mathrm{CC}(35-37 \mathrm{~cm})$.

Genus PROTOELLIPSODINIUM Davey and Verdier 1971
Type species. Protoellipsodinium spinocristatum Davey and Verdier, 1971 , p. 28 , pl. 5 , figs. 2,5 , and 11 .

\section{Protoellipsodinium? sp. LICE \\ (Pl. 7, Fig. 10)}

Description. Proximochorate to skolochorate dinoflagellate cysts with subspherical to ellipsoidal central body. Autophragm slightly granulous. Numerous rigid hollow acuminate nontabular processes, with broad perfored bases, taper distally to terminate in a point. Short antapical process with distal spines. Precingular archeopyle P (4).

Remarks. Individuals are folded, so it is difficult to see the ambitus of the central body and the antapical process.

Dimensions. Central body: length $43 \mu \mathrm{m}$, width $34 \mu \mathrm{m}$. Processes: length $9-10 \mu \mathrm{m}$. Antapical process: length $11 \mu \mathrm{m}$. (One specimen, well oriented.) Central body: diameter $40(45) 47 \mu \mathrm{m}$. (Ten specimens.)

Occurrences. See Figure 1, no. 2: Samples 103-641A-7X, CC (18-20 $\mathrm{cm})$, to $103-641 \mathrm{~A}-6 \mathrm{X}-7,26-29 \mathrm{~cm}$.

Genus Pterodinium Eisenack, 1958 emend. Yun, 1981

Type species. Pterodinium aliferum Eisenack, 1958, p. 395-396, pl. 24 , fig. 6 .

Pterodinium cressimurstus (Davey and Williams, 1966a) comb. nov.

Synonymy. 1966a: Hystrichosphaera crassimurata Davey and Williams, p. 39 , pl. 1 , fig. 11 .

1967: Hystrichosphaera cingulata var. polygonalis Clarke and Verdier, 1967, p. 47 , pl. 8 , figs. 7 and 8 , text fig. 20 .

1968: Clarke, Davey, Williams, and Sarjeant considered $H$. cingulata var. polygonalis Clarke and Verdier, 1967, to be Jun. synonym of H. crassimurata Davey and Williams, 1966a.

1970: Spiniferites crassimuratus (Davey and Williams, 1966a) Sarjeant, 1970, p. 76.

Description. Proximochorate and suturocavate dinoflagellate cyst with subspherical central body. Parasutural septa, cavate, relatively high, with irregular crests. The coel is confined to the base of parasutural septa. Surface of the central body smooth. Gonyaulacoid paratabulation, Stype. Precingular archeopyle P (4), operculum free.

Remarks. The thickened periphragm on the central body is the face of the coel running along the parasutures.

\section{Pterodinium crassimuratus subsp. A.}

(Pl. 7, Fig. 11)

Description. Proximochorate, suturocavate dinoflagellate cyst, with subspherical central body. Cavate parasutural septa, high with irregular crests. Endophragm and periphragm oppressed between suturocoels. Perforated surface with two type of holes. Microholes $(0.5 \mu \mathrm{m})$ on the periphragm of the suturocoels, holes (1-2 $\mu \mathrm{m})$ on the paraplates. Paratabulation gonyaulacoid, S type: A and lu elongated, with 1 or absent $\mathrm{A} / \mathrm{lu}$ septa. lu is included in the parasulcus area. Precingular archeopyle P (4), operculum free.

Dimensions. Central body: length $40-42-43 \mu \mathrm{m}$, width $32-35-40 \mu \mathrm{m}$. Septa: height 8-9 $\mu \mathrm{m}$ (Three specimens.)

Occurrence. See Figure 1, no. 19: Samples 103-641A-7X-5, 21-23 $\mathrm{cm}$, to $103-641 \mathrm{~A}-6 \mathrm{X}, \mathrm{CC}(27-30 \mathrm{~cm})$.

\section{Forma $\mathrm{B}$ in Masure, in press, a}

$$
\text { (Pl. 7, Fig. 13) }
$$

Description. Skolochorate two-layered dinoflagellate cyst with subspheroidal to subellipsoidal central body, with apical and antapical protrusions. Endophragm and periphragm oppressed between processes. Endophragm slightly granular, periphragm smooth with ridges. Intratabular hollow processes with ridges, closed distally or open? and generally rectangular in ambitus. Gonyaulacoid paratabulation: pr?, 4', 6 ${ }^{\prime \prime}$, xc, 5-6"', $1 \mathrm{p}, 1$ '”'. Precingular archeopyle $2 \mathrm{P}(3-4$ ?), opercular pieces free.

Remarks. Individuals are very rare.

Dimensions. Central body: length $42 \mu \mathrm{m}$, width $38 \mu \mathrm{m}$. Processes: length $14 \mu \mathrm{m}$, width $8 \mu \mathrm{m}$. (One specimen, well oriented.)

Occurences. See Figure 1, no. 40: Samples 103-641A-7X-3, 24-26 $\mathrm{cm}$, to $103-641 \mathrm{~A}-7 \mathrm{X}-1,85-86 \mathrm{~cm}$. 


\section{APPENDIX D}

\section{Dinoflagellate Cysts Taxa List}

Achomosphaera crassipellis (Deflandre and Cookson, 1955) Stover and Evitt, 1978. (39)

Achomosphaera ramulifera (Deflandre, 1937) Evitt, 1963. (20)

Achomosphaera sagena Davey and Williams, 1966a; Pl. 7, Fig. 1. (37)

Achomosphaera triangulata (Gerlach, 1961) Davey and Williams, 1969. (13)

Aldorfia deflandrei (Clarke and Verdier, 1967) Stover and Evitt, 1978. (35)

Ascodinium scabrosum Cookson and Hughes, 1964. (41)

Ascodinium verrucosum subsp. verrucosum Cookson and Hughes, 1964. (7)

Canningia scabrosa Cookson and Eisenack, 1970. (43)

Canningia sp. A. MPK sensu Davey, 1979. (42)

Chlamydophorella nyei Cookson and Eisenack, 1958. (28)

Cleistosphaeridium huguoniotii (Valensi, 1955) Davey, 1969. (24)

Codoniella campanulata (Cookson and Eisenack, 1960) Downie and Sarjeant, 1965. (52)

Coronifera oceanica Cookson and Eisenack, 1958. (53)

Cyclonephelium chabaca Below, 1981. (36)

Cyclonephelium compactum Deflandre and Cookson, 1955. (58)

Cyclonephelium distinctum subsp. distinctum Deflandre and Cookson, 1955. (25)

Dapsilidinium duma (Below, 1982) Lentin and Williams, 1985. (32)

Dapsilidinium laminaspinosum (Davey and Williams, 1966b) Lentin and Williams, 1981. (18)

Ellipsodinium rugulosum Clarke and Verdier, 1967. (26)

Eurydinium ingramii (Cookson and Eisenack, 1970) Stover and Evitt, 1978; Pl. 7, Fig. 2. (56)

Florentinia mantellii (Davey and Williams, 1966b) Davey and Verdier, 1973. (9)

Gonyaulacysta cornuta (Cookson and Eisenack, 1962) Yun, 1981. (34)

Hapsocysta dictyota Davey, 1979. (44)

Heterosphaeridium? heteracanthum (Deflandre and Cookson, 1955) Eisenack and Kjellström, 1971. (4)

Hystrichodinium pulchrum subsp. densispinum (Deflandre, 1936) Lentin and Williams, 1973. (21)

Hystrichosphaeridium bowerbankii Davey and Williams, 1966b; Pl. 7, Fig. 3. (54)

Hystrichosphaeridium ovum Deflandre, 1935; PI. 7, Fig. 4. (8)

Hystrichostrogylon membraniphorum Agelopoulos, 1964; Pl. 7, Fig. 5. (12)

Kiokansium williamsii Singh, 1983. (6)

Kiokansium sp. GAL; Pl. 7, Fig. 6. (50)

Kleithriasphaeridium loffrense Davey and Verdier, 1976. (5)

Leberidocysta chlamydata (Cookson and Eisenack, 1962) Stover and Evitt, 1978. (27)

Leptodinium? delicatum (Davey, 1969) Sarjeant, 1969; Pl. 7, Fig. 7. (10)

Litosphaeridium arundum (Cookson and Eisenack, 1960) Davey, 1979. (45)

Litosphaeridium siphoniphorum subsp. siphoniphorum (Cookson and Eisenack, 1958) Davey and Williams, 1966b. (23)

Maghrebinia perforata (Clarke and Verdier, 1967) Below, 1981, emend. Masure, in press, b. (11)

Microdinium ornatum Cookson and Eisenack, 1960; Pl. 7, Fig. 8. (57)

Microdinium spinosum Brideaux and McIntyre, 1975. (46)

Odontochitina costata Alberti, 1961. (47)

Odontochitina operculata (Wetzel, 1933) Deflandre and Cookson, 1955. (14)

Oligosphaeridium complex (White, 1842) Davey and Williams, 1966b. (55)

Oligosphaeridium pulcherrimum (Deflandre and Cookson, 1955) Davey and Williams, 1966b. (29)

Palaeohystrichophora infusorioides Deflandre, 1935. (16)

Pervosphaeridium cenomaniense (Norrick, 1976) Below, 1982. (3)

Pervosphaeridium pseudhystrichodinium (Deflandre, 1937) Yun, 1981; Pl. 7, Fig. 9. (38)

Prolixosphaeridium conulum Davey, 1969. (48)

Protoellipsodinium? sp. LICE; PI. 7, Fig. 10. (2)

Pterodinium cingulatum subsp. cingulatum (Wetzel, 1933) Below, 1981. (1)
Pterodinium crassimuratus (Davey and Williams, 1966a) comb. nov. Pterodinium crassimuratus subsp. A; Pl. 7, Fig. 11. (19)

Spiniferites multibrevis (Davey and Williams, 1966a) Below, 1982. (31)

Spiniferites ramosus subsp. ramosus (Ehrenberg, 1838) Loeblich and Loeblich, 1966. (17)

Spiniferites scabrosus (Clarke and Verdier, 1967) Lentin and Williams, 1975. (30)

Subtilisphaera? habibi Masure, in press, a. (33)

Trichodinium castanea (Deflandre, 1935) Clarke and Verdier, 1967. (15)

Trithyrodinium suspectum (Manum and Cookson, 1964) Davey, 1969; Pl. 7, Fig. 12. (51)

Xenascus ceratioides (Deflandre, 1937) Lentin and Williams, 1973. (49)

Xiphophoridium alatum (Cookson and Eisenack, 1962) Sarjeant, 1966. (22)

Forma B, in Masure, in press, a; Plate 7, Fig. 13. (40)

\section{Acritarchs}

Cymstiosphaera radiata Wetzel, 1932. (59)

Tubulospinosa oblongata Davey, 1970; Pl. 7, Fig. 14. (60)

\section{APPENDIX E}

Pollen Grains and Spores Taxa List SPORITES

Anteturma PROXIMEGERMINANTES

Turma Triletes-Azonales

Auritulinasporites deltaformis Burger, 1966

Cyathidites minor Couper, 1953

Matonisporites equiexinus Couper, 1958

Gleicheniidites senonicus Ross, 1949

Clavifera triplex (Bolch.) Kemp, 1970

Todisporites major Couper, 1958

Chomotriletes triangularis Bolkhovitina, 1956

Lophotriletes babsae (Brenner, 1963) Singh, 1971

Ornamentifera echinata (Bolkhovitina) Bolkhovitina, 1966

Concavisporites variverrucatus Couper, 1958

Vadazsisporites sacali Deàk and Combaz, 1967

Vadazsisporites urkuticus (Deàk) Deàk and Combaz, 1967

Cicatricosisporites brevilaesuratus Couper, 1958

Cicatricosisporites crimensis (Bolkhovitina) Pocock, 1964

Cicatricosisporites mediostriatus (Bolkhovitina) Pocock, 1964

Cicatricosisporites minor (Bolkhovitina) Pocock, 1964

Cicatricosisporites venustus Deàk, 1963

Corrugatisporites toratus Weyland and Greifeld, 1953

Appendicisporites jansonii Pocock, 1962

Plicatella tricornitata (Weyland and Krieger) Potonié, 1960

Klukisporites areolatus Singh, 1971

Perotrilites rugulatus Couper, 1958

Turma Zonales

Densoisporites sp.

Patellasporites aequatorialis Krutzsch, 1959

Patellasporites echinatus Groot and Groot, 1962

Cingutriletes sp.

Camarozonosporites insignis Norris, 1967

Taurocusporites minor Singh, 1964

Stratriletes coronarius Pierce, 1961

Turma Monoletes

Reticulosporis microfoveolatus (Pierce) Skarby, 1978

Anteturma VARIEGERMINANTES

Turma Saccites

Abietineaepollenites microreticulatus Groot and Penny, 1960

Abietineaepollenites minimus Couper, 1958

Alisporites elongatus Kemp, 1970

Alisporites microsaccus (Couper) Pocock, 1962

Alisporites thomasii Couper, 1958

Caytonipollenites pallidus (Reissinger) Couper, 1958

Cedripites canadensis Pocock, 1962

Parvisaccites radiatus Couper, 1958 
Podocarpidites potomacensis Brenner, 1963 Podocarpidites radiatus Brenner 1963

Rugubivesiculites rugosus Pierce, 1961

Turma Kryptaperturates

Araucariacites australis Cookson, 1947

Applanopsis dampiere (Balme) Döring, 1961

Applanopsis trilobatus (Balme) Döring, 1961

Cerebropollenites sp.

Classopollis major Groot and Groot, 1962

Classopollis obidosensis Groot and Groot, 1962

Exesipollenites tumulus Balme, 1957
Turma Plicates

cf. Asteropollis asteroïdes Hedlund and Norris, 1968 Monocolpopollenites sp.

Monosulcites major Kemp, 1970

Retitricolporites insolitimorus Laing, 1975

Tricolpopollenites sp.

Turma Poroses

Atlantopollis microreticulatus Krutzsch, 1967

Atlantopollis reticulatus Krutzsch, 1967

Complexiopollis helmigii (Van Amerom) Sole de Porta, 1978

Complexiopollis sp. 


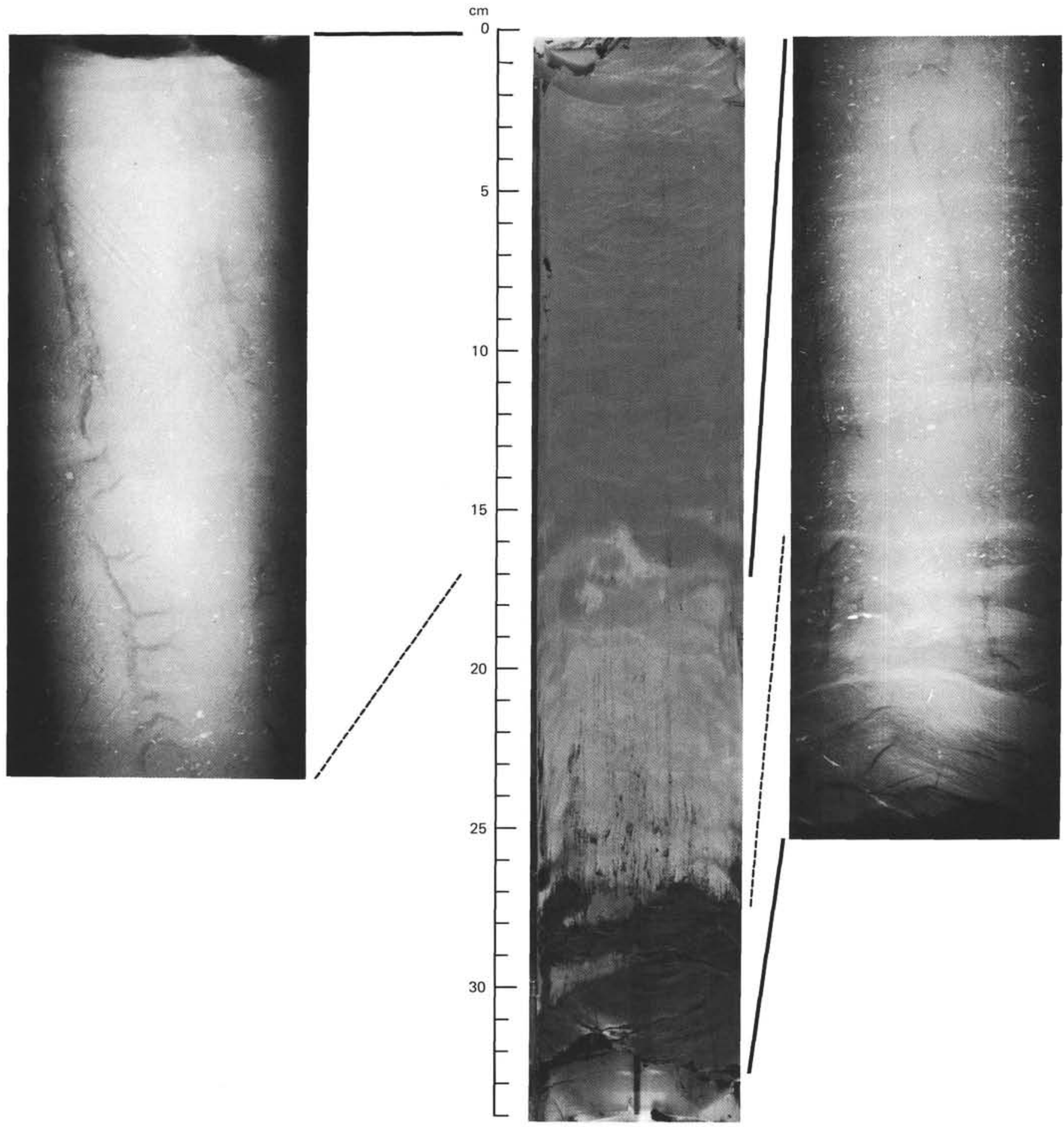

Plate 1. Photograph and X-ray micrograph of the upper part of the CTBE black band, greenish gray (reduced) basal part of the Plantagenet Formation, and lower part of the brown clay sequence $(0-34 \mathrm{~cm}$ interval in Section 103-641A-6X-7). 


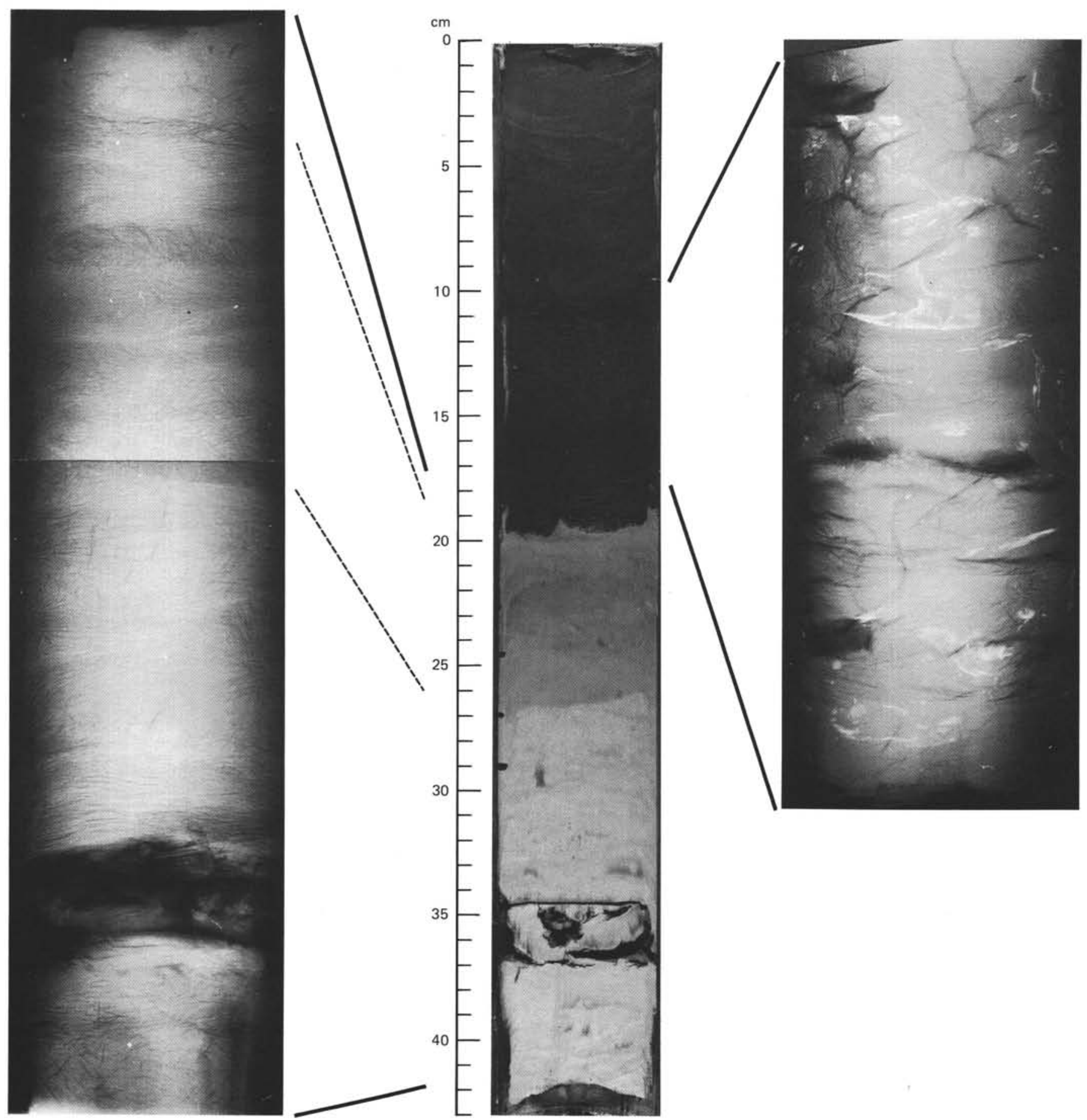

Plate 2. Photograph of the lower part of the CTBE black band, underlying dark green highly condensed layer (Event 2), and clayey marlstones of the uppermost Hatteras Formation (0-43 cm interval in Section 103-641A-6X, CC). X-ray micrographs of $9.5-17.5$ and $17.5-41.5 \mathrm{~cm}$ intervals. 


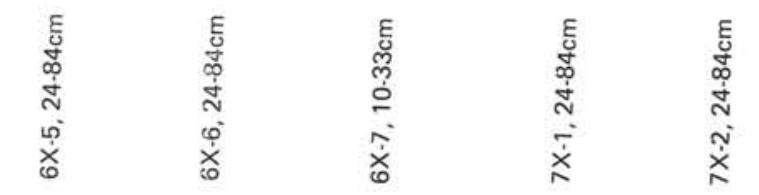

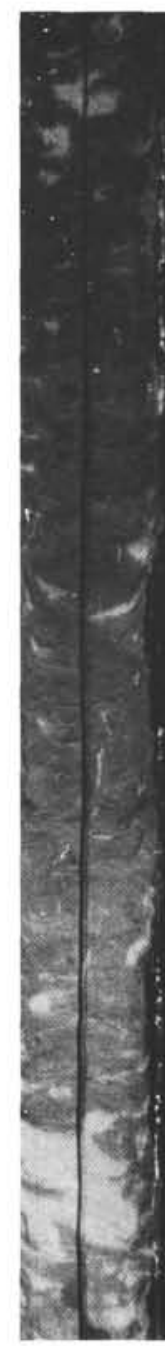

1

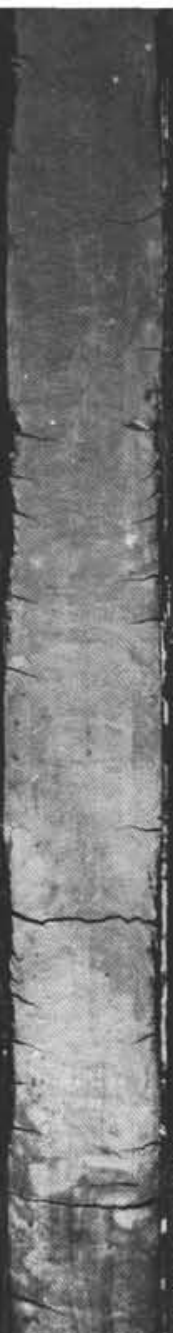

2

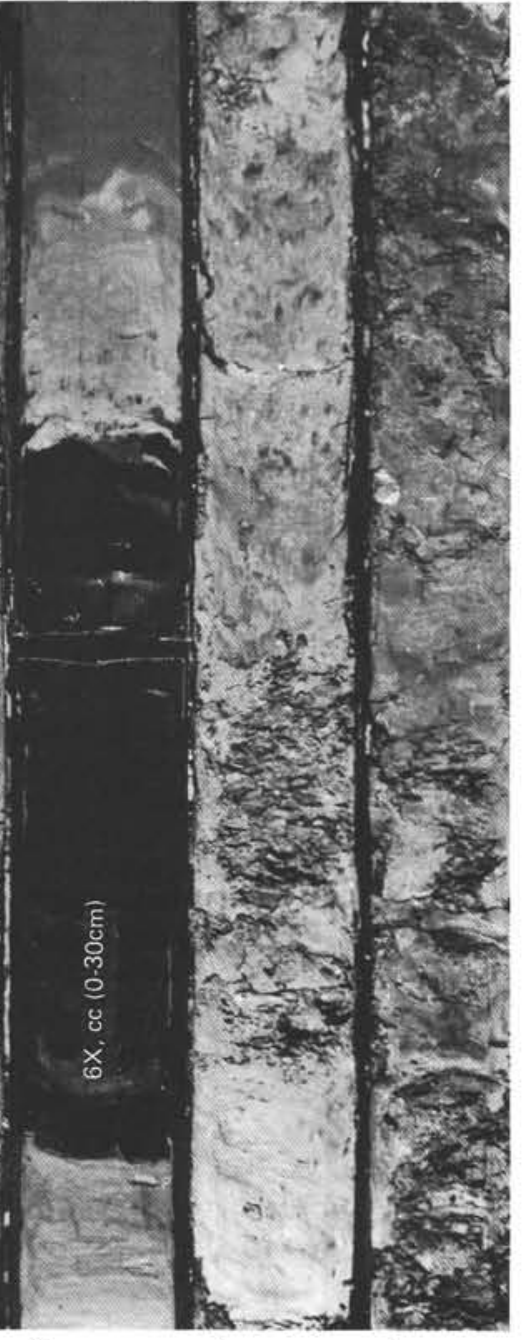

4

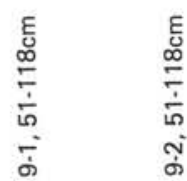
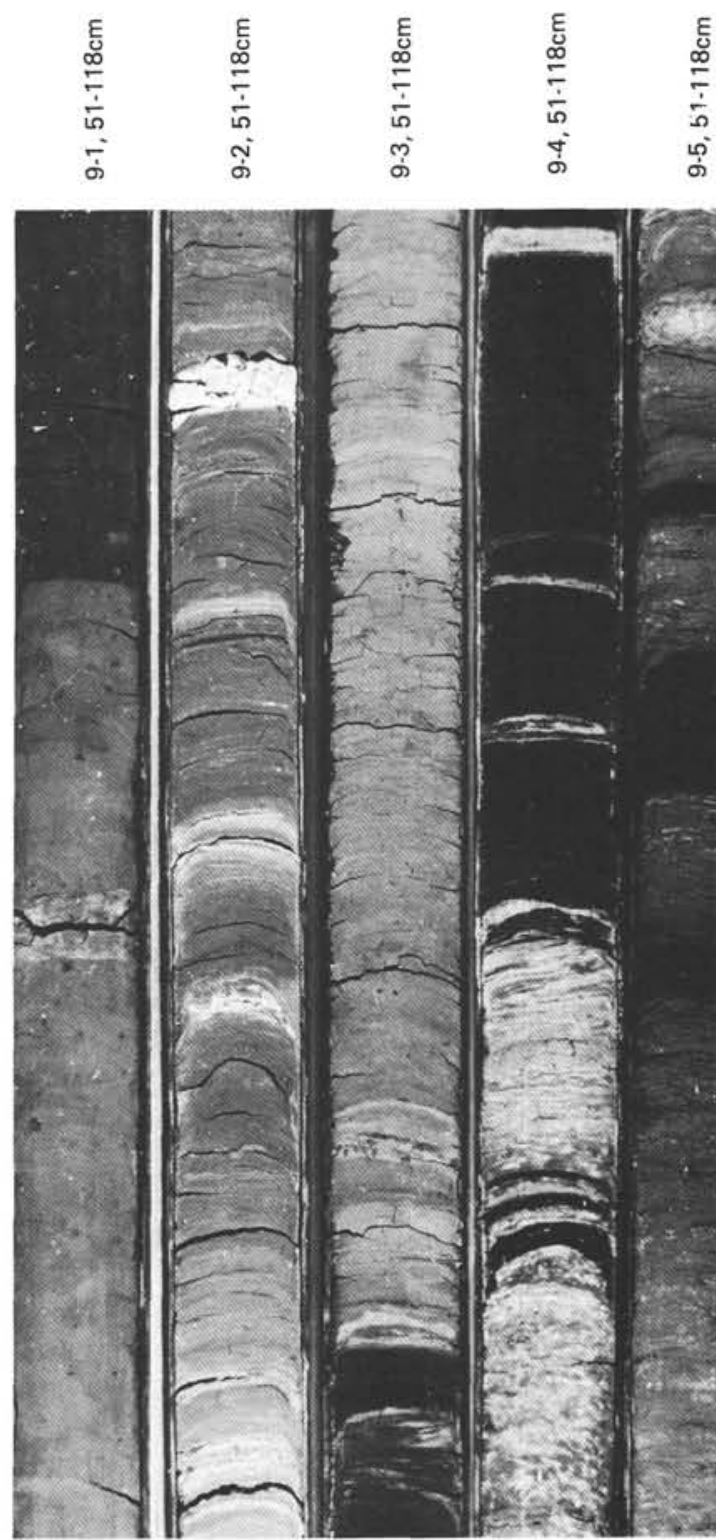

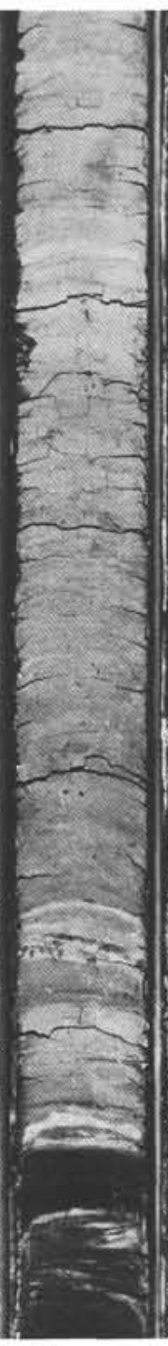

3

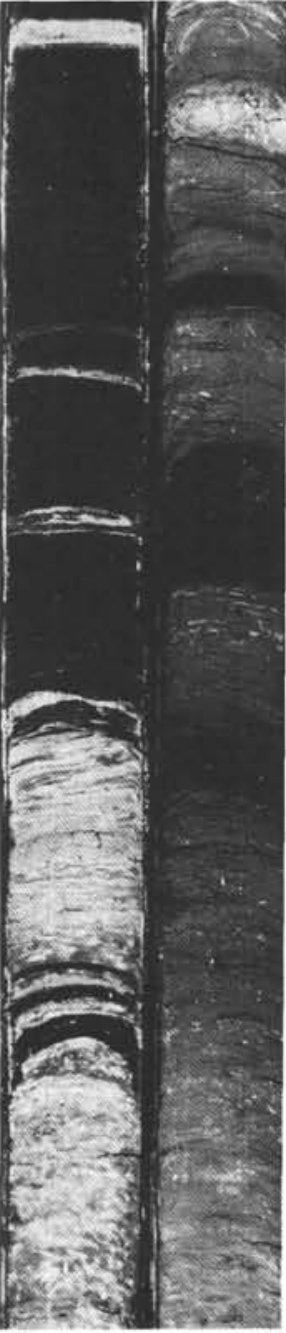

5

Plate 3. 1. Middle Cretaceous lithology from Hole 641A. Unit A, the brown clay with manganese-rich layers of the Planatagenet Formation, includes the upper part of Section 6X-5. Unit B grayish zeolite-rich claystone is in the middle part of Section 6X-7. The Unit C CTBE black shale layer is at the base of Section 6X-7 and the core catcher. 2. Middle Cretaceous lithology of the condensed CTBE interval at Site 105. Section 1 shows the lowermost part of the Plantagenet Formation (Unit A at Site 641) with the typical brown clays at the base and a dark, manganiferous layer at the top. At the base of the formation, the typical brown claystone color disappears, with gradual replacment by reddish followed by gray-green, strongly zeolitic claystones, with intercalations of white and yellow layers (?parts Unit B at Site 641); thus, they are comparable with the radiolarian-rich zeolitic reddish upper part of the CTBE interval at Site 398. The contact to the underlying CTBE black shale in Section 3 is sharp. The CTBE black shale layer (Unit C at Site 641) in Sections 3 and 4 is an almost homogenous black shale, interrupted only by centimeter-scale green layers. The carbonate content remains near zero, the zeolite and pyrite content is high (up to $55 \%$ for the former, which is indicative of a high radiolarian content at the time of deposition, and up to $25 \%$ for the latter), and the TOC of the black shales reaches values of up to $25 \%$, with organic matter of mixed marine and terrestrial origin (de Graciansky et al., 1982; Herbin et al., 1986b). The contact to the underlying Hatteras Formation, at $86 \mathrm{~cm}$ in Section 4, is sharp. The lower part of Section 4 and Section 5 (Units D and E at Site 641) show the uppermost part of the Hatteras Formation, with thick green claystone layers intercalated with thin black shale layers ( $1 \%-5 \%$ TOC and organic matter of terrestrial origin), the typical facies of this formation. 

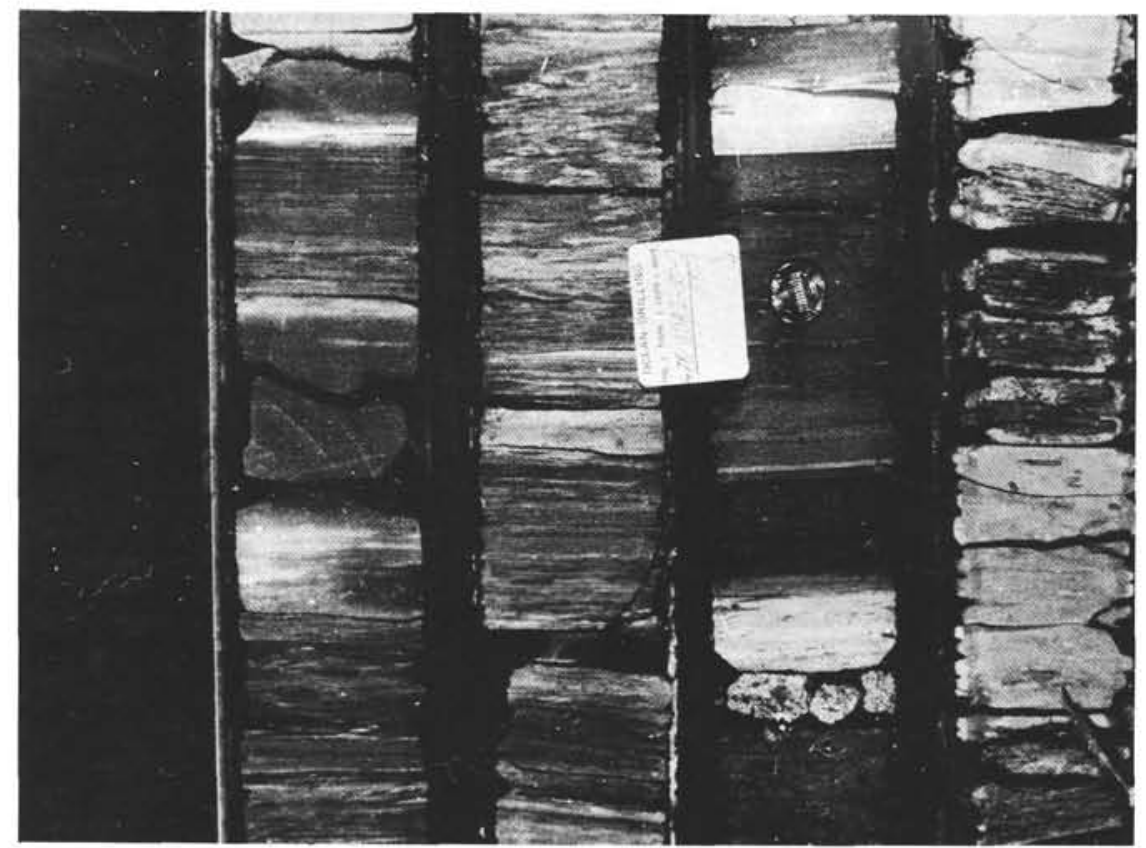

1

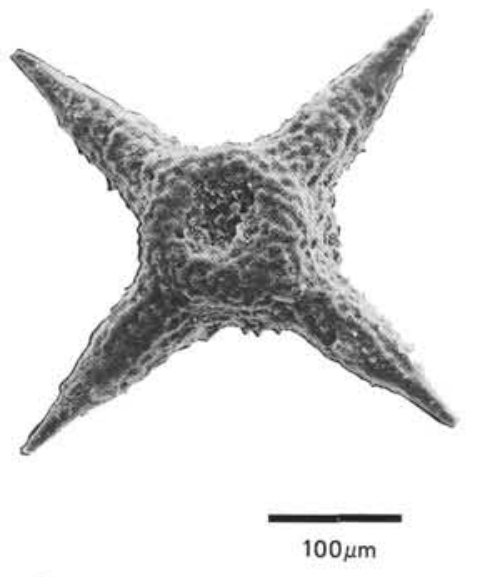

3

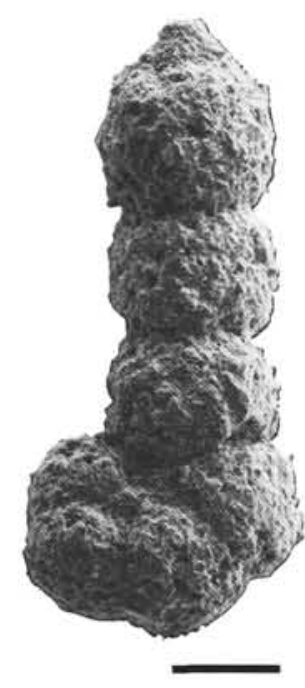

4
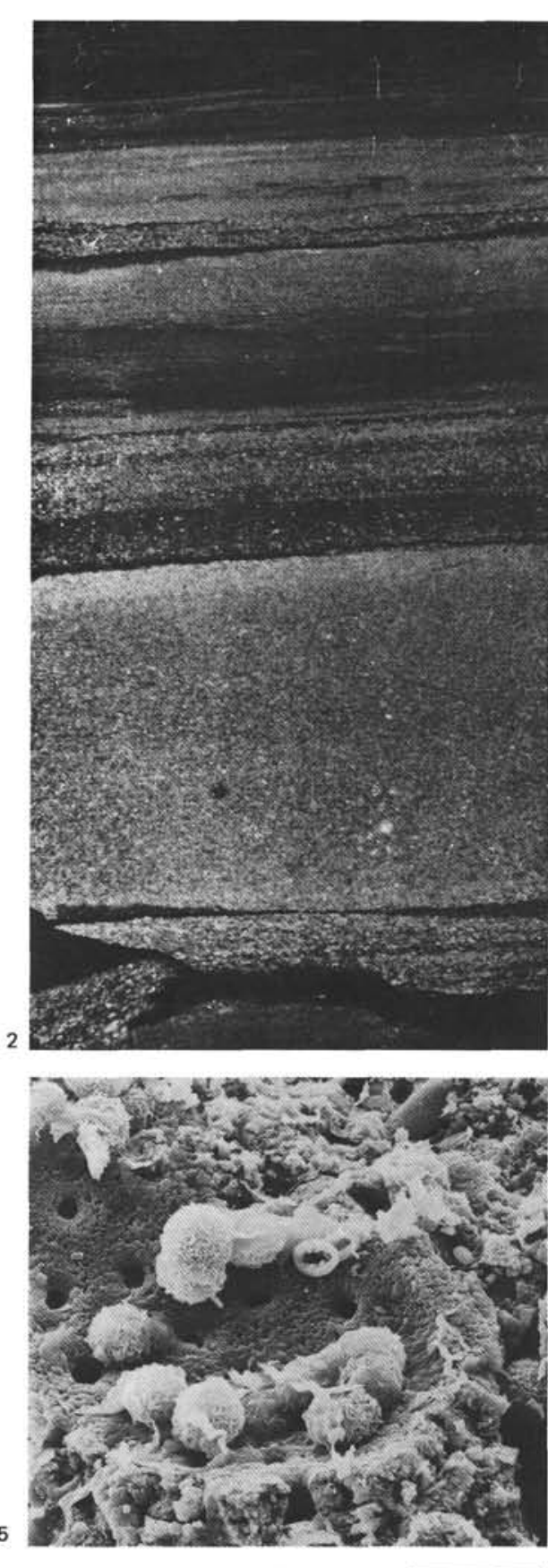

$10 \mu \mathrm{m}$

Plate 4. 1. CTBE interval sediment cycles at Hole 398D. Section intervals from left to right are $55-2,54-81 \mathrm{~cm}, 56-1,54-81 \mathrm{~cm}, 56-2,54-81 \mathrm{~cm}$, $56-3,54-81 \mathrm{~cm}$, and 56-4, 54-81 cm. Section 55-2 (far left) shows the lowermost part of the Plantagenet Formation (Unit A at Site 641) with typical manganiferous brownish claystones. At the base of the formation (the top of the second interval from left), the typical brown color of the claystones disappears, with replacement by reddish siliceous and zeolitic claystones bearing opal-CT-replaced radiolarians. The remaining underlying lithologies of the CTBE interval consist of alternations of siliceous dark to black shales, grayish silty marlstones and claystones, and some redeposited layers. Note the coarse-grained calcareous turbidite at the base of Section 56-3, 54-81 cm (fourth interval from left). 2. Radiolarian-rich layer within Section 398D-56-1. Radiolarians are enriched in the lighter layers and in graded sections (lower part of the micrograph) (Sample 398D-56-1, 45-56 cm). 3. Crucella cachensis (Sample 398D-56-2, 23-27 cm). 4. Haplophragmium lueckei (Section 103-641A-5X, CC). 5. Silicified calcareous turbiditic layer. Note opal-CT lepispheres growing on the internal wall of a foraminifer test (Sample 398D-56-3, 57-61 cm). 

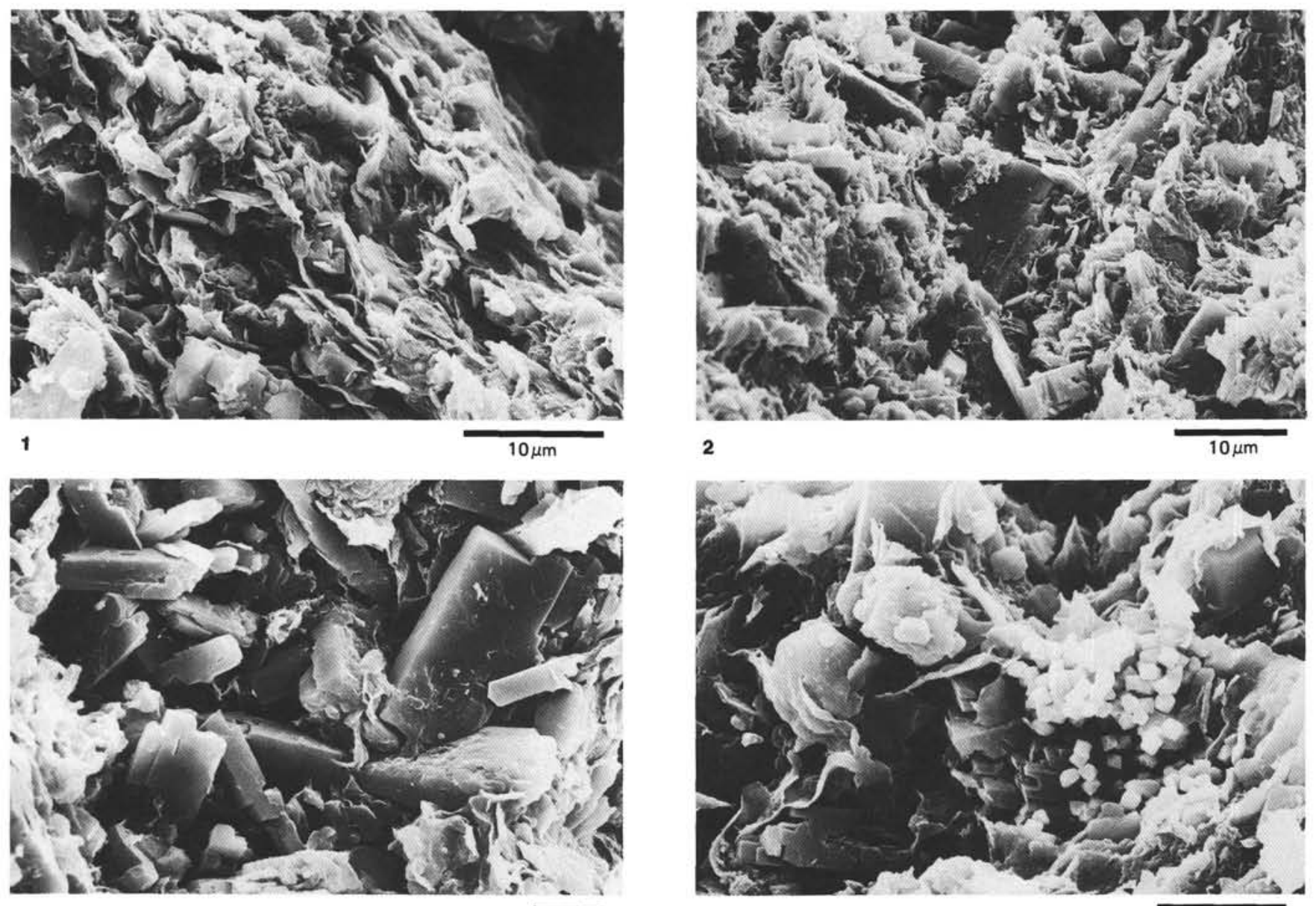

2

$10 \mu \mathrm{m}$

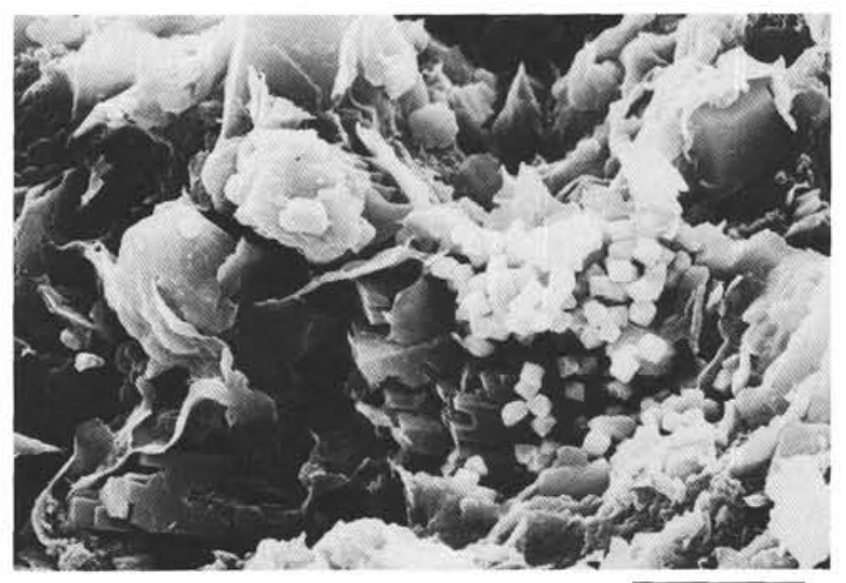

4

$4 \mu \mathrm{m}$

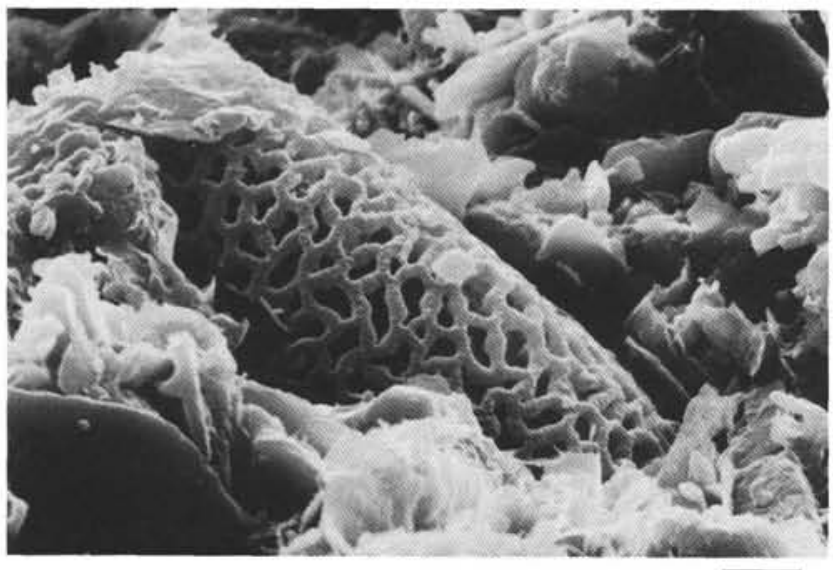

5

$2 \mu \mathrm{m}$

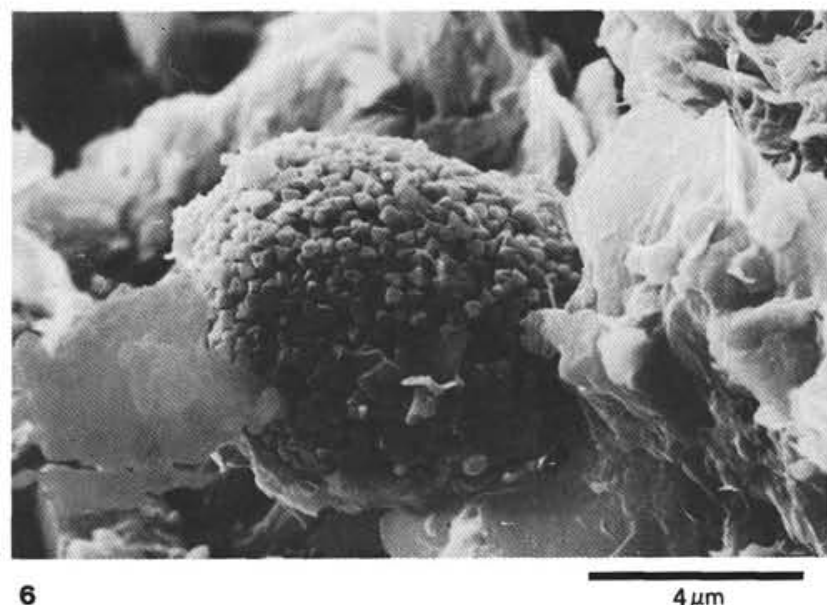

Plate 5. SEM micrograph of black shale (Unit C, Site 641) with features typical of the CTBE black shales (Sample 103-641A-6X-7, 31-33 cm). 1. Fine lamination in black shale (tabular crystals are secondary-formed gypsum). 2. Zeolite crystals (clinoptilolite/heulandite) growing perpendicular or angular to the lamination of the shale. 3. Zeolite growth obscures the original layering of clay minerals. 4. Single pyrite crystals on zeolite grown in a late diagenetic stage. 5. ollen grain in clay/zeolite matrix. EDAX analysis revealed a pyritic preservation or coating of the grain. $\mathbf{6}$. Framboidal pyrite incorporated in recrystallized clay minerals. 


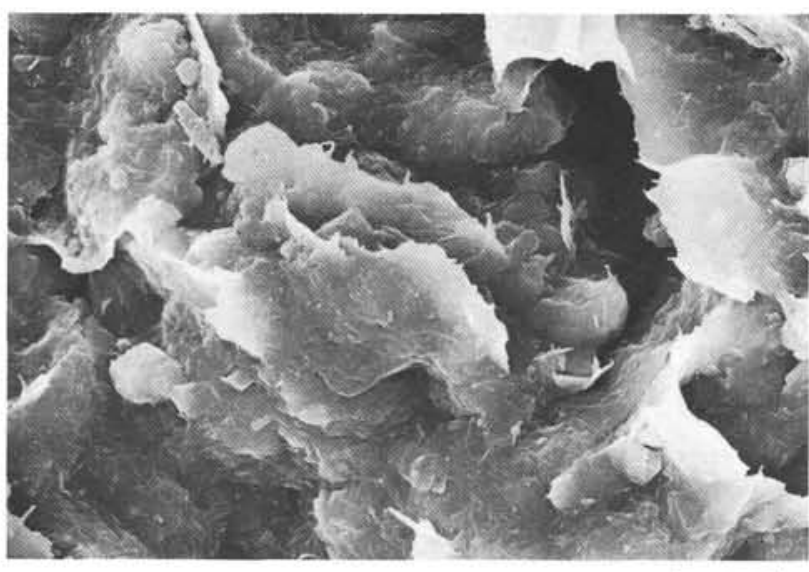

1

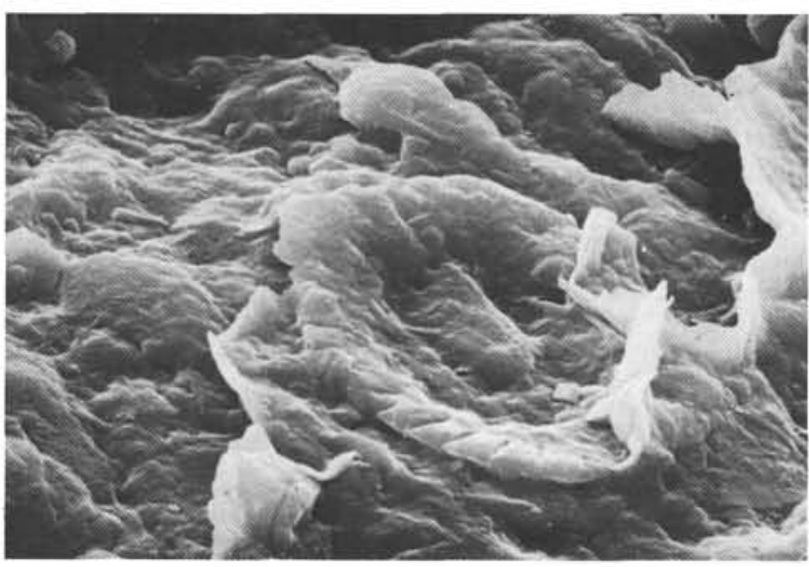

3

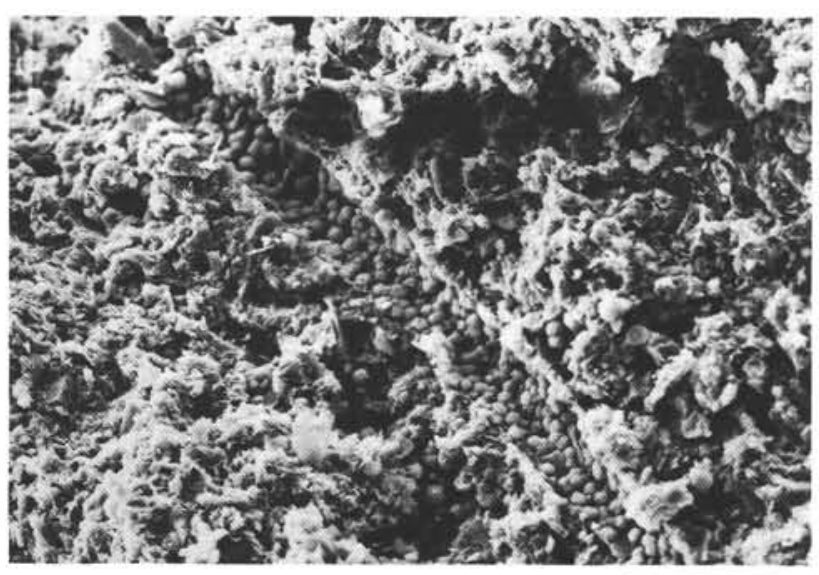

5

$10 \mu \mathrm{m}$

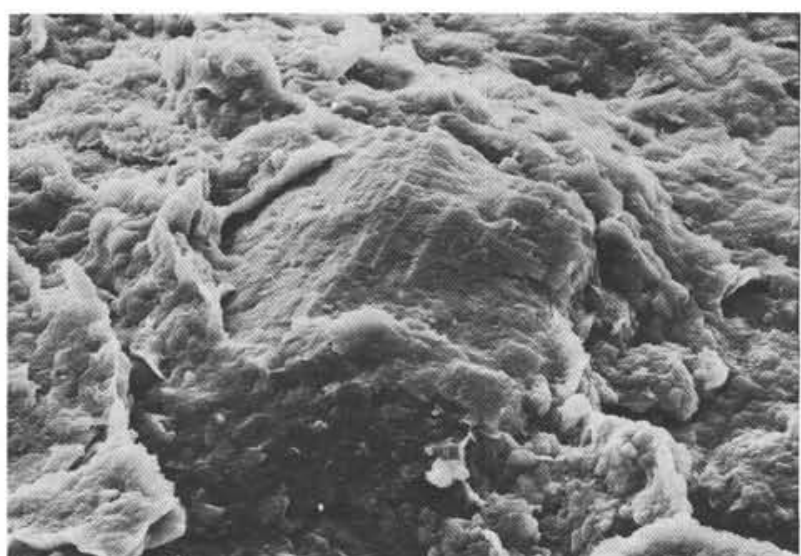

2

$10 \mu \mathrm{m}$

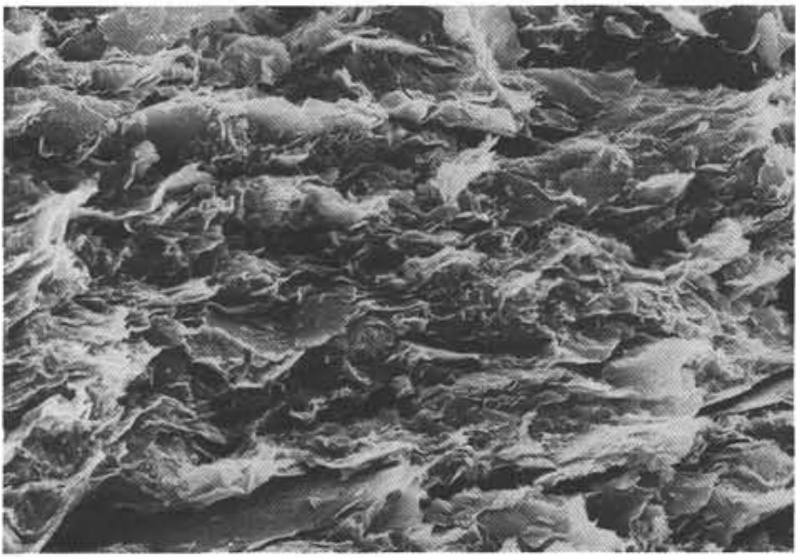

4

$4 \mu \mathrm{m}$

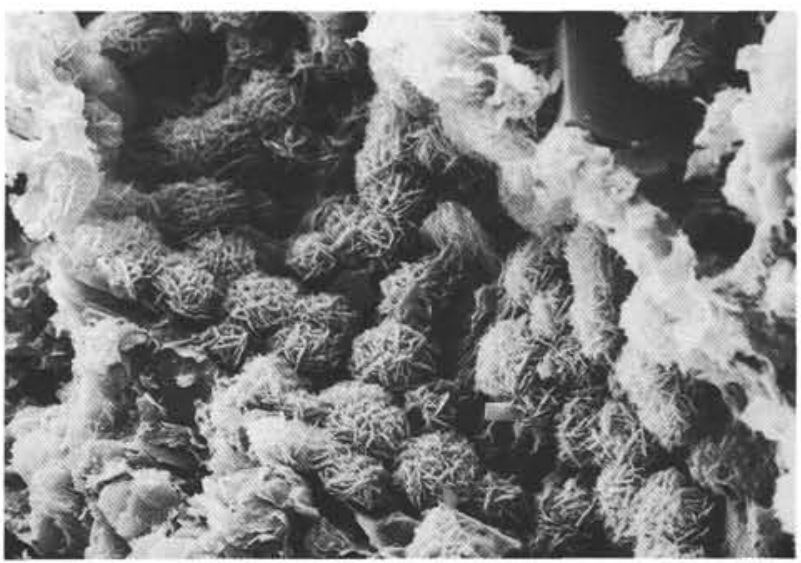

6

$10 \mu \mathrm{m}$

Plate 6. SEM micrographs. 1. Unit A sediment texture with extensively recrystallized clay (Sample 103-641A-6X-7, 11-14 cm). 2. Dolomite crystal (pseudoradiolarian) in Unit A brown clay (Sample 103-641A-6X-7, 11-14 cm). 3. The youngest sample in Unit D with a carbonate content (slight) showing strongly dissoluted nannofossils (Sample 103-641A-6X, CC [21-24 cm]). 4. Aptian/Albian black shale (Sample 103-641C-3R, CC $[12-16 \mathrm{~cm}])$. The laminated pattern of the clay minerals is quite distinct, with incorporated framboidal pyrite. Compare with Figure 5 . 5. Bioturbation tube at the boundary between slightly oxic (gray-green) and anoxic (black) layers (Sample 398D-56-2, 139-141 cm). 6. Enlargement of Figure 5 showing the distict tube wall. The inner walls of the tube are coated with opal-C/T lepispheres. 


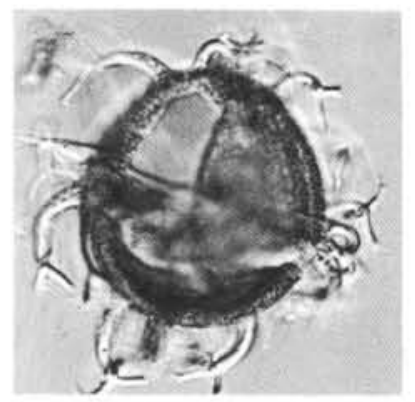

1

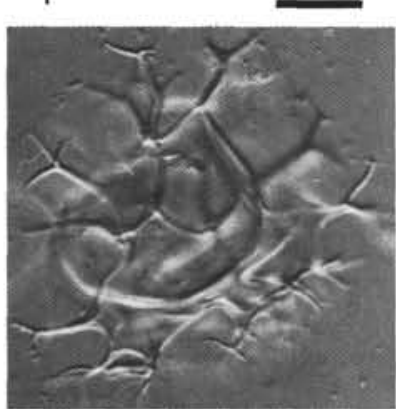

5

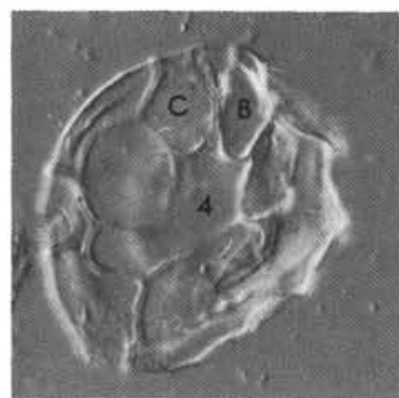

7B

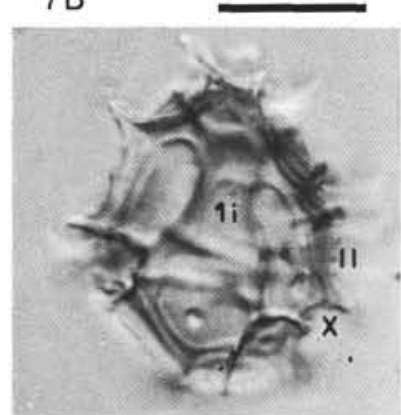

11

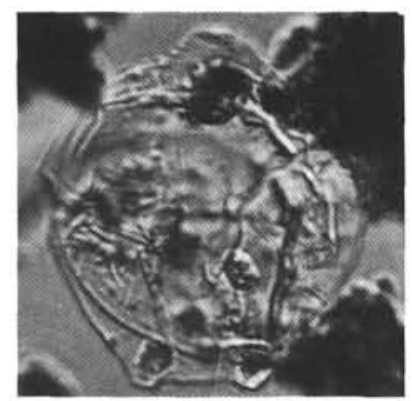

2

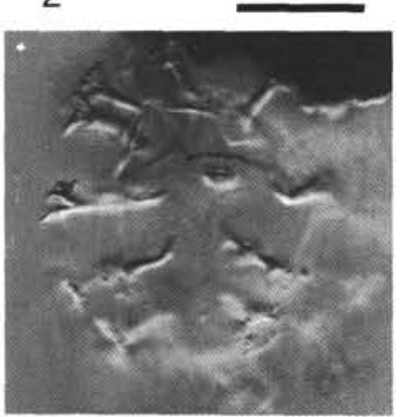

6A

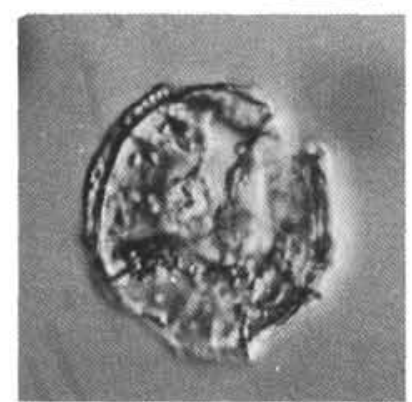

8

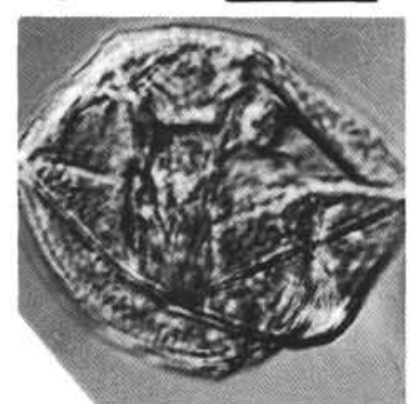

12

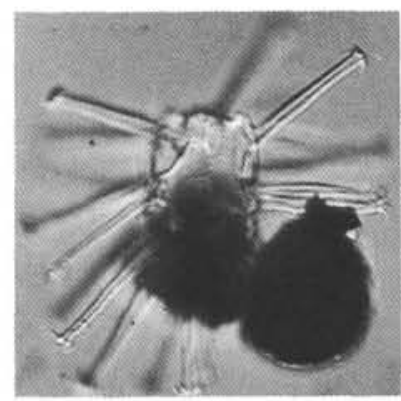

3

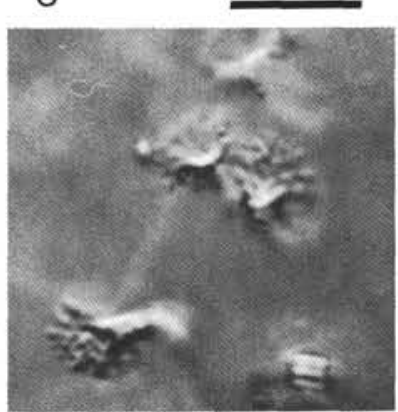

$6 B$
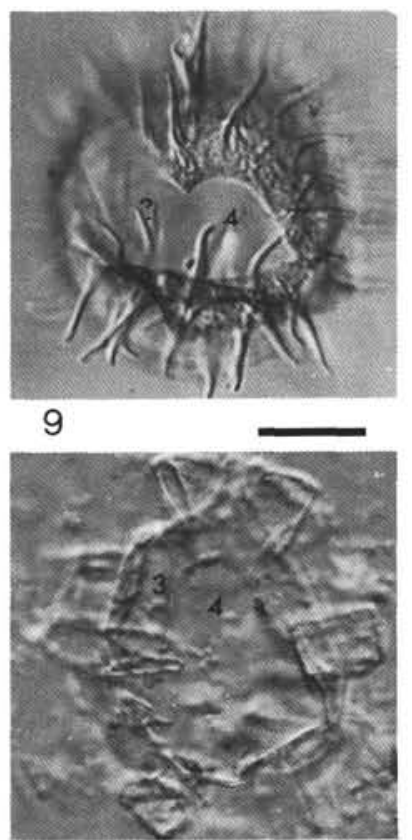

13

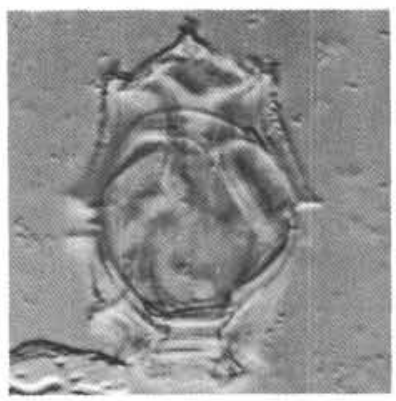

4

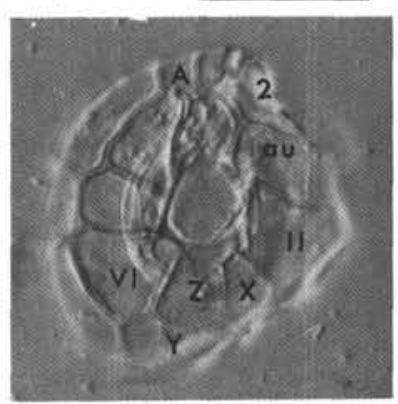

$7 \mathrm{~A}$

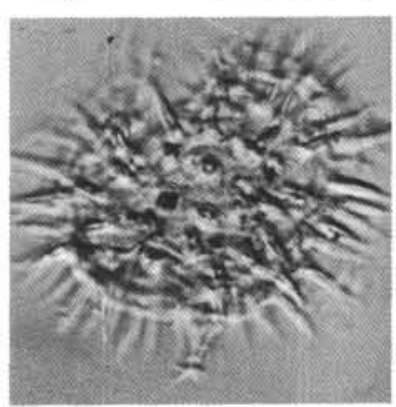

10

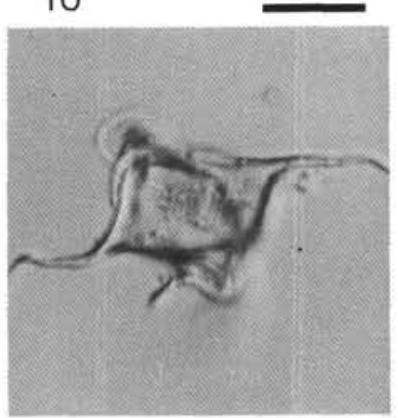

14

Plate 7. Dinoflagellates. Scale bar $=20 \mu \mathrm{m}$. 1. Achomosphaera sagena, length $84 \mu \mathrm{m}$, dorsal view, slide 1: QR 50-51. Sample 103-641A-6X, CC $(27-30 \mathrm{~cm})$. 2. Euryfinium ingramii, length $56 \mu \mathrm{m}$, high focus ventral view, slide 1 : W 46 . Sample 103-641A-6X, CC $(18-21 \mathrm{~cm})$. 3. Hystrichosphaeridium bowerbankii, total length $66 \mu \mathrm{m}$, general view, slide 1: UV 37. Sample 103-641A-6X, CC (27-30 cm). 4. Hystrichosphaeridium ovum, length $64 \mu \mathrm{m}$, general view, slide b: VW 47 . Sample 103-641A-7R, CC $(18-20 \mathrm{~cm})$. 5. Hystrichostrogylon membraniphorum, length $68 \mu \mathrm{m}$, focus on the lateral pericoel, slide a: T 34. Sample 103-641A-7R, CC (15-20 cm). 6. Kiokansium sp. GAL., length $76 \mu \mathrm{m}$, (A) high focus on the archeopyle, (B) focus on the distal end of the processes, note the perforated funnel and the thin spines on its rims, slide 1: D 38-39. Sample 103-641A-6X, CC (27$30 \mathrm{~cm}$ ). 7. Leptodinium? delicatum, length $45 \mu \mathrm{m}$, (A) ventral view, (B) low-focus ventral view, slide a: PQ 37-38, Sample 103-641A-7R, CC (18-20 $\mathrm{cm}$ ). 8. Microdinium ornatum, length $38 \mu \mathrm{m}$, slide 1: WX 36-37. Sample 103-641A-6X-7, 26-29 cm. 9. Pervosphaeridium pseudhystrichodinium, total width $76 \mu \mathrm{m}$, high focus on the dorsal face in apical view, archeopyle 2P (3-4), slide 1: 0-28. Sample 103-641A-6X, CC (35-37 cm). 10. Protoellipsodinium? sp. LICE., length $56 \mu \mathrm{m}$, lateral view, slide 1: E 24-25. Sample 103-641A-6X, CC (27-30 cm). 11. Pterodinium crassimuratus subsp. $\mathrm{A}$, length $62 \mu \mathrm{m}$, high focus right lateral side, note hole on the paraplates, slide 1: DE 43-44. Sample 103-641A-6X, CC (27-30 cm). 12. Trithyrodinium suspectum, width $55 \mu \mathrm{m}$, see 3I archeopyle, slide 1: ST 49. Sample 103-641A-6X-7, 26-29 cm. 13. Forma B in Masure, in press, length $65 \mu \mathrm{m}$, dorsal view with precingular archeopyle 2P (3-4?), slide 1: DE 47-48. Sample 103-641A-7X-3, 24-26 cm. 14. Tubulospinosa oblongara, width 69 $\mu \mathrm{m}$, slide 2: NO 30-31. Sample 103-641A-6X-7, 26-29 cm. 

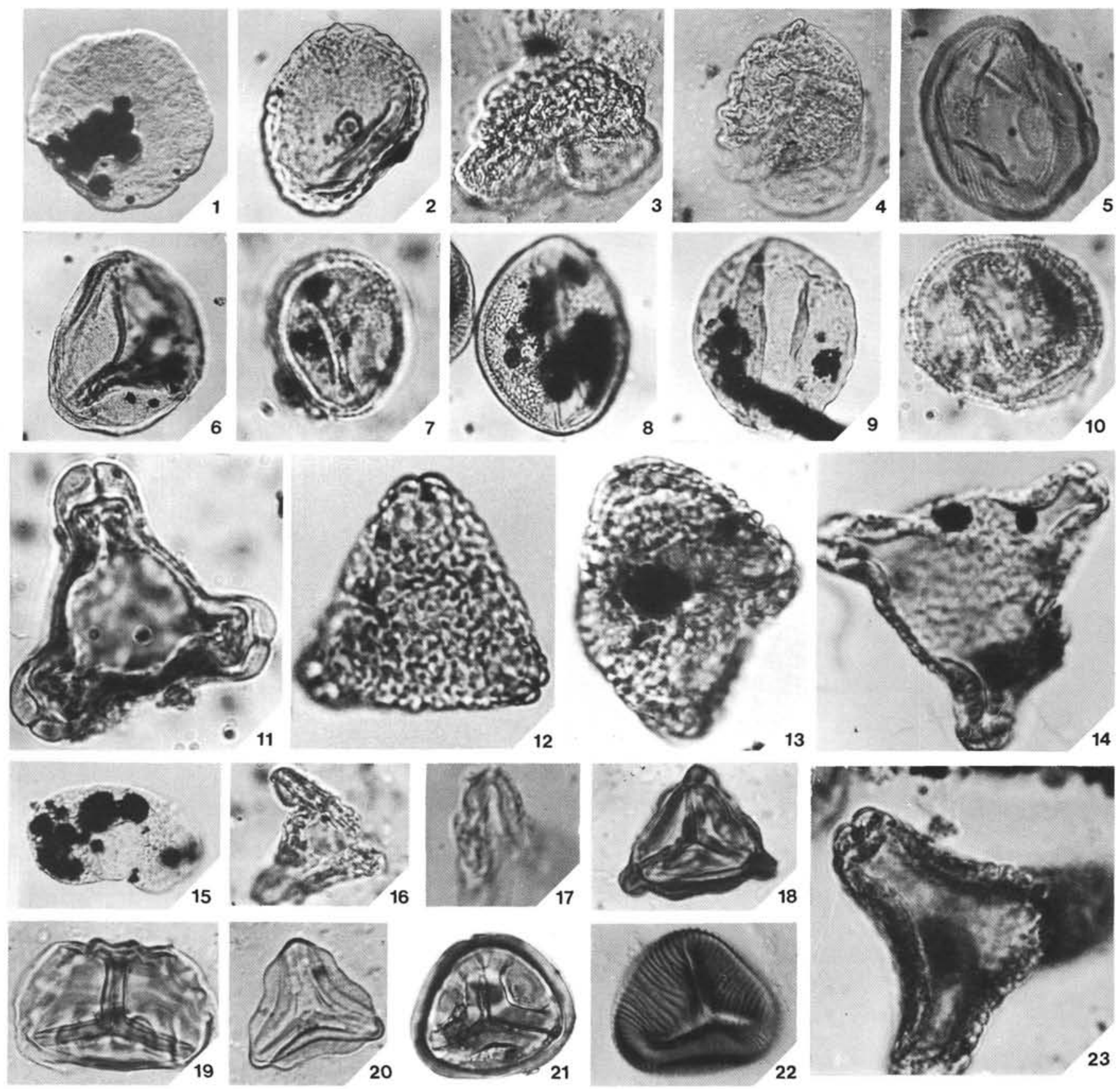

Plate 8. Pollen grains and spores. 1. Applanopsis trilobatus (Balme) Döring, 1961, size $50 \mu \mathrm{m}$. Sample 103-641C-16R-8, 25-27 cm. 2. Applanopsis dampieri (Balme) Döring, 1961, size $42.5 \mu \mathrm{m}$. Sample 103-641A-6X, CC (6-11 cm). 3 and 4. Rugubivesiculites rugosus Pierce, 1961, size (3) central body $52 \times 27 \mu \mathrm{m}$ and (4) $26 \times 34 \mu \mathrm{m}$. Sample 103-641A-7X-3, 24-26 cm. 5. Classopollis major Groot and Groot, 1962 , size $32.4 \mu \mathrm{m}$. Sample 103-641A-7X-3, 24-26 cm. 6. Araucariacites australis Cookson, 1947, size $53 \mu \mathrm{m}$. Sample 103-641A-6X, CC (5-11 cm). 7. Retitricolporites insolitimorus Laing 1975, size $17.5 \times 13.5 \mu \mathrm{m}$. Sample 103-641A-6X, CC $(35 \mathrm{~cm})$. 8. Alisporites elongatus Kemp, 1970 , size $60 \times 43 \mu \mathrm{m}$. Sample 103-641C-11R-2, 114-116 cm. 9. Monosulcites major Kemp, 1970, size $57.5 \times 45 \mu \mathrm{m}$. Sample 103-641C-14R-4, 32-24 cm. 10. Cf. Asteropollis asteroides Hedlund and Norris, 1968, size 12. $5 \mu \mathrm{m}$. Sample 103-641A-6X-7, 31-33 cm. 11. Complexiopollis helmigii (Van Amerom) Sole de Porta, 1978, size $25 \mu \mathrm{m}$. Sample 103-641A-6X, CC (35-37 cm). 12 and 13. Atlantopollis reticulatus Krutzsch, 1967, variation in size (12) $34 \mu \mathrm{m}$, (13) cf. Latipollis $32.5 \times 23 \mu \mathrm{m}$. Sample 103-641A-6X, CC $(8-11 \mathrm{~cm})$. 14. Atlantopollis microreticulatus Krutzsch, 1967, size 27.5 $\mu \mathrm{m}$. Sample 103-641A-6X, CC $(8-11 \mathrm{~cm})$. 15. Caytonipollenites pallidus (Reissinger) Couper, 1958, size $40 \times 22.5 \mu \mathrm{m}$. Sample 103-641C-14R-4, 32-34 cm. 16 and 17. Normapolles?, size $21 \mu \mathrm{m}$. Sample 103-641A-7R-3, 24-26 cm. 18. Clavifera triplex (Bolkhovitina) Kemp, 1970, size $35 \mu \mathrm{m}$. Sample 103$641 \mathrm{~A}-7 \mathrm{X}-3,24-26 \mathrm{~cm}$. 19. Perotrilites rugulatus Couper, 1958, size $50 \mu \mathrm{m}$. Sample 103-641A-7R-3, 24-26 cm. 20. Gleicheniidites senonicus Ross, 1949, size 32.5 $\mu \mathrm{m}$. Sample 103-641A-7X-3, 24-26 cm. 21. Chomotriletes triangularis Bolkhovitina, 1956, size 37.5 $\mu \mathrm{m}$. Sample 103-641A-6X, CC $(8-11 \mathrm{~cm})$. 22. Cicatricosisporites venustus Deàk, 1963. Sample 103-641A-7X-3, 24-26 cm. 23. Atlantopollis reticulatus Krutzsch, 1967, cf. Latipollis size $27.5 \mu \mathrm{m}$. Sample 103-641A-6X, CC $(8-11 \mathrm{~cm})$. 